\title{
Overview of Environmental and Hydrogeologic \\ Conditions at Merrill Field Airport, Anchorage, Alaska
}

By Allan S. Nakanishi

U.S. GEOLOGICAL SURVEY

Open-File Report 95-171

Prepared in cooperation with the

FEDERAL AVIATION ADMINISTRATION

Anchorage, Alaska

1995

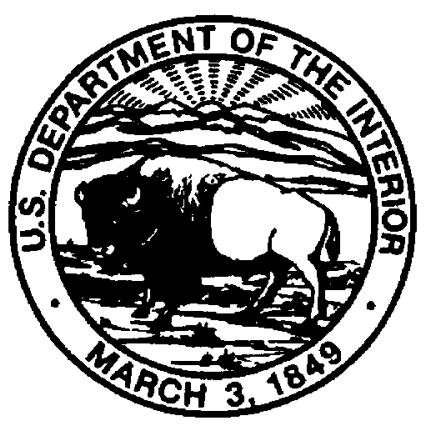




\section{U.S. DEPARTMENT OF THE INTERIOR \\ BRUCE BABBITT, Secretary}

U.S. GEOLOGICAL SURVEY

Gordon P. Eaton, Director

For additional information write to:

District Chief

U.S. Geological Survey

4230 University Drive, Suite 201

Anchorage, AK 99508-4664
Copies of this report may be purchased from:

U.S. Geological Survey

Earth Science Information Center

Open-File Reports Section

Box 25286, MS 517

Federal Center

Denver, CO 80225-0425 


\section{CONTENTS}

Abstract $\ldots \ldots \ldots \ldots \ldots \ldots \ldots \ldots \ldots \ldots \ldots \ldots \ldots \ldots \ldots \ldots \ldots \ldots \ldots \ldots \ldots \ldots$

Introduction $\ldots \ldots \ldots \ldots \ldots \ldots \ldots \ldots \ldots \ldots \ldots \ldots \ldots \ldots \ldots \ldots \ldots \ldots \ldots$

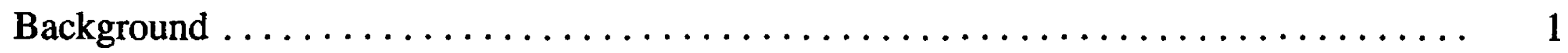

Location and history $\ldots \ldots \ldots \ldots \ldots \ldots \ldots \ldots \ldots \ldots \ldots \ldots \ldots \ldots \ldots$

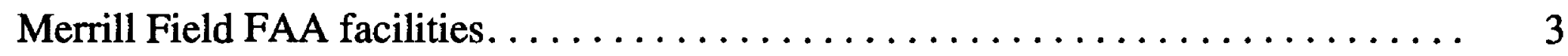

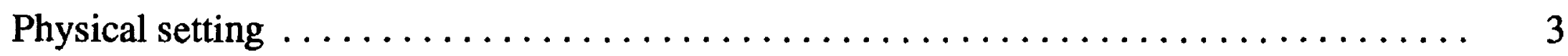

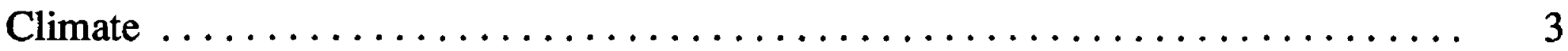

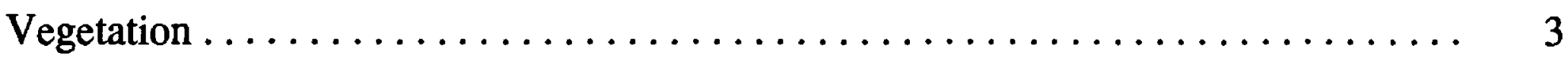

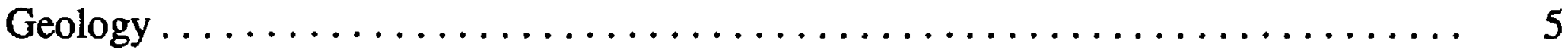

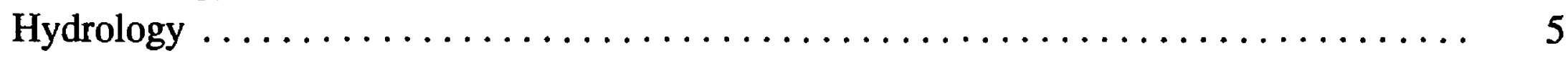

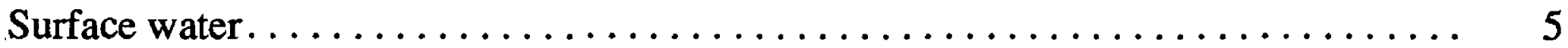

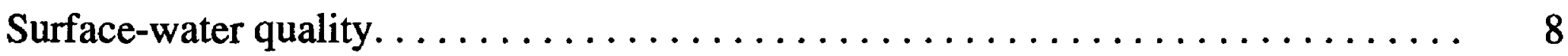

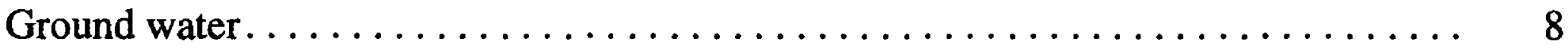

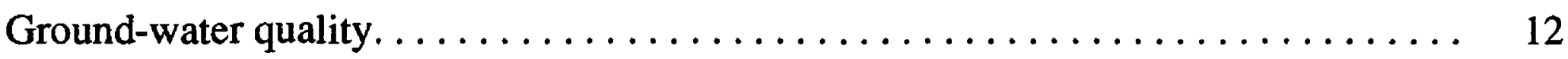

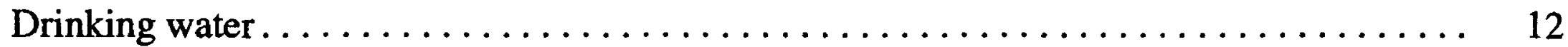

Present drinking-water supplies $\ldots \ldots \ldots \ldots \ldots \ldots \ldots \ldots \ldots \ldots \ldots \ldots \ldots \ldots \ldots \ldots \ldots$

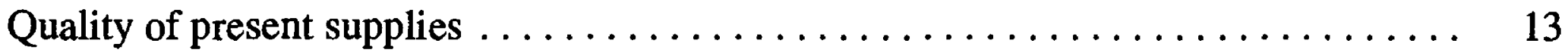

Alternative drinking-water sources . . . . . . . . . . . . . . . . 13

Summary . . . . . . . . . . . . . . . . . . . . . . . . . . . . . 13

References cited. . . . . . . . . . . . . . . . . . . . . . . . . . . . . 14

Appendix 1. Water-quality records for North Fork Chester Creek and drains near the

Merrill Field airport. . . . . . . . . . . . . . . . . . . . A-1

Appendix 2. Well inventory and water-quality data for wells in the Merrill Field airport area A-13

\section{FIGURES}

1-4. Maps showing:

1. Location of Merrill Field Airport, Anchorage, Alaska. . . . . . . . . . . 2

2. Chester Creek drainage basin . . . . . . . . . . . . . . . . . . 6

3. Five-year average, mean daily discharge for Chester Creek at Arctic Boulevard, Anchorage for water years $1989-93 \ldots \ldots \ldots \ldots \ldots \ldots \ldots \ldots$

4. Location of observation wells and geologic section through wetlands and the landfill

\section{TABLES}

1. Mean monthly temperature, precipitation, and snowfall for the period 1952 to 1987 , Anchorage International Airport, Anchorage, Alaska . . . . . . . . 4

2. Information on wells in the Merrill Field airport area $\ldots \ldots \ldots \ldots \ldots \ldots$

3. Wells near the Merrill Field airport area in which water sample concentrations exceeded drinking-water regulations. 


\begin{tabular}{rll}
\hline Multiply & \multicolumn{1}{c}{ By } & To obtain \\
millimeter $(\mathrm{mm})$ & 0.03937 & inch \\
meter $(\mathrm{m})$ & 3.281 & foot \\
kilometer $(\mathrm{km})$ & 0.6214 & mile \\
hectare $(\mathrm{ha})$ & 2.471 & acres \\
square kilometer $\left(\mathrm{km}^{2}\right)$ & 0.3861 & square mile \\
meter per day $(\mathrm{m} / \mathrm{d})$ & 3.281 & foot per day \\
liter per day $(\mathrm{L} / \mathrm{d})$ & 0.2642 & gallon per day \\
cubic meter per second $\left(\mathrm{m}^{3} / \mathrm{s}\right)$ & 35.31 & cubic foot per second \\
& & \\
degree Celsius $\left({ }^{\circ} \mathrm{C}\right)$ & ${ }^{\circ} \mathrm{F}=1.8 \times{ }^{\circ} \mathrm{C}+32$ & degree Fahrenheit $\left({ }^{\circ} \mathrm{F}\right)$ \\
& &
\end{tabular}

\section{Sea level:}

In this report "sea level" refers to the National Geodetic Vertical Datum of 1929--a geodetic datum derived from a general adjustment of the first-order level nets of both the United States and Canada, formerly called Sea Level Datum of 1929. 


\title{
Overview of Environmental and Hydrogeologic Conditions at Merrill Field Airport, Anchorage, Alaska
}

\author{
by Allan S. Nakanishi
}

\begin{abstract}
The Federal Aviation Administration (FAA) operates facilities on or near Merrill Field airport in the Municipality of Anchorage, Alaska. The airport is surrounded by developed urban areas and up to 80 percent of the land surface is covered by asphalt, concrete, buildings, or other impervious surfaces. The airport area is underlain by unconsolidated glacial, alluvial, estuarine deposits, weakly lithified sedimentary rocks, and a large landfill. Ground water is available from both unconfined and confined aquifers within the unconsolidated deposits; however, most residential, commercial, and industrial consumers in the area obtain water from the municipal water-supply system.
\end{abstract}

\section{INTRODUCTION}

The Federal Aviation Administration (FAA) owns and (or) operates airway support and navigational facilities throughout Alaska. At many of these sites, fuels and potentially hazardous materials such as solvents, polychlorinated biphenyls, and pesticides may have been used and (or) disposed of. To determine if environmentally hazardous materials have been spilled or disposed of at the sites, the FAA is conducting environmental studies mandated under the Comprehensive Environmental Response, Compensation, and Liability Act (CERCLA or "Superfund Act") and the Resource Conservation and Recovery Act (RCRA). To complete these more comprehensive environmental studies, the FAA requires information on the hydrology and geology of areas surrounding the sites. This report, the product of compilation, review, and summary of existing hydrologic and geologic data by the U.S. Geological Survey, in cooperation with the FAA, provides such information for the FAA facilities at Merrill Field Airport and nearby areas in Anchorage, Alaska.

\section{BACKGROUND}

\section{Location and History}

Anchorage is in south-central Alaska and had a population of approximately 240,000 in 1990, which was approximately 50 percent of the total State population (Alaska Department of Community and Regional Affairs, 1993). An area known locally as the "Anchorage Bowl" or the "Bowl," encompassing an area of approximately $470 \mathrm{~km}^{2}$ (fig. 1), is bounded on the west by Cook Inlet, on the north by Knik Arm, on the east by the Chugach Mountains, and on the south by Turnagain Arm. The Merrill Field FAA facilities, on Merrill Field municipal airport, is in the Municipality of Anchorage at about lat $61^{\circ} 12^{\prime} \mathrm{N}$. and long $149^{\circ} 50^{\prime} \mathrm{W}$. 


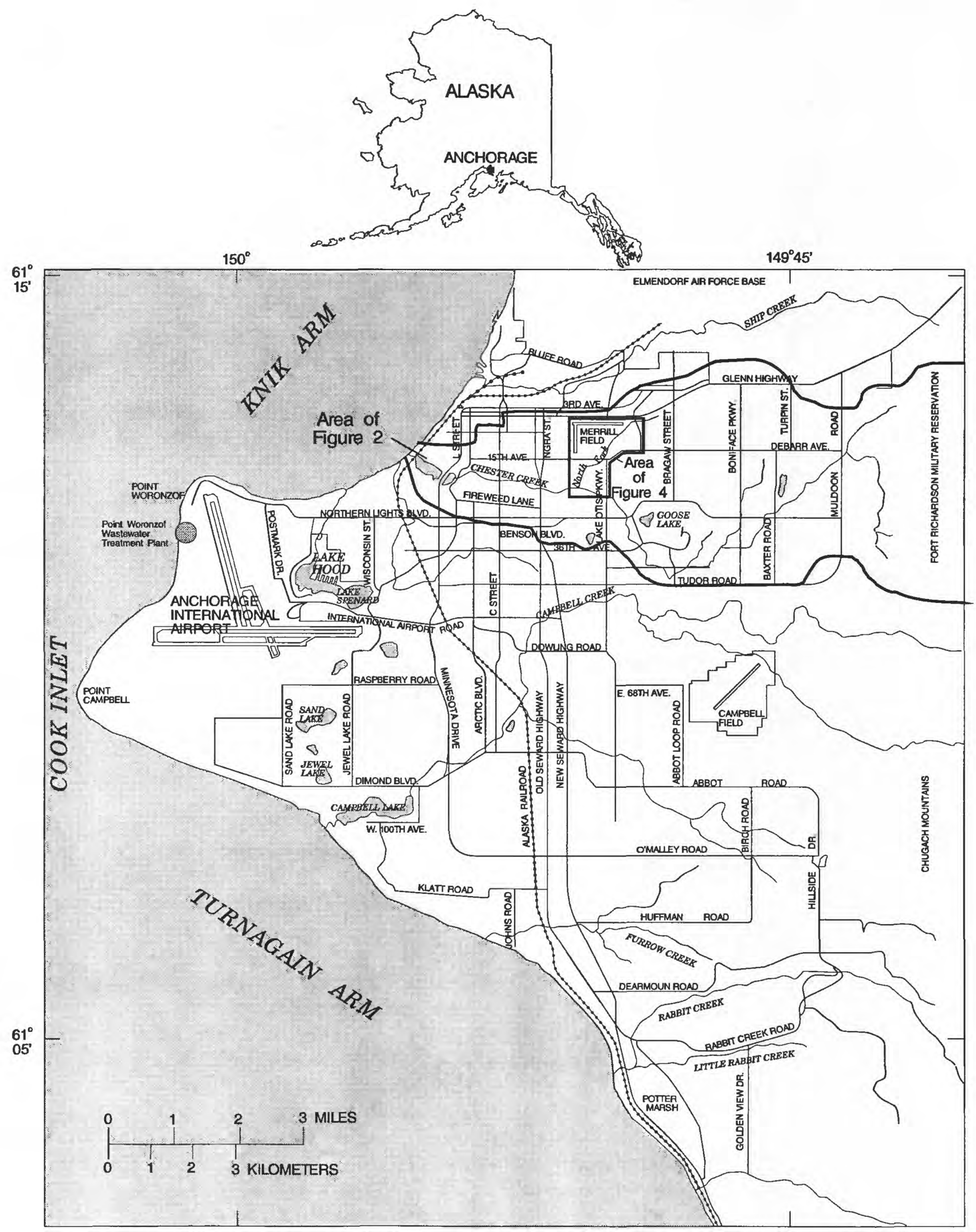

Figure 1. Location of Merrill Field Airport, Anchorage, Alaska. 
In the 1940's, Merrill Field airport was constructed on what was then the outskirts of Anchorage. Along the southeast side of the airport was a bluff that overlooked North Fork Chester Creek and below the bluff were wetlands (Brunett, 1990). The Merrill Field solid-waste landfill was created in the 1940's by dumping refuse off the bluff near the east end of the Merrill Field Airport runway. When the landfill was closed in 1987, approximately 80 ha of the original wetlands had been covered with soil and refuse to an average thickness of about $10 \mathrm{~m}$.

\section{Merrill Field FAA Facilities}

The FAA owns and operates a flight service station (FSS), air traffic control tower (ATCT), visual approach slope indicators (VASI), and runway end identification lights (REIL) on Merrill Field airport (Ecology and Environment Inc., 1994). Approximately 30 FAA personnel operate and maintain the FAA facilities at Merrill Field airport. A detailed description of FAA facilities near Merrill Field and an investigation of potential sources of contamination is included in a report by Ecology and Environment, Inc. (1994).

\section{PHYSICAL SETTING}

\section{Climate}

Anchorage is located in a transitional climate zone, situated between maritime and continental climate zones. Seasonal precipitation patterns in this zone are not sharply defined, fluctuate from year to year, and may resemble those of either the maritime or continental climate zones (Hartman and Johnson, 1984). The mean annual temperature for Anchorage at the Anchorage International Airport (AIA), about $8 \mathrm{~km}$ southwest of the Merrill Field airport, is $2.1^{\circ} \mathrm{C}$, but temperatures range from a July mean maximum of $18.3^{\circ} \mathrm{C}$ to a January mean minimum of about $-13.2^{\circ} \mathrm{C}$. Precipitation increases with increasing elevation eastward toward the Chugach Mountains (Patrick and others, 1989). Mean annual precipitation at the AIA is about $390 \mathrm{~mm}$ and mean annual snowfall is approximately $1,760 \mathrm{~mm}$ (Leslie, 1989). Most rainfall occurs from July through October. Mean monthly temperature, precipitation, and snowfall for the weather station at the AIA are summarized in table 1 .

\section{Vegetation}

Selkregg and others (1972) provide a map and description of vegetation types in the Anchorage area. Vegetation near the Merrill Field airport generally includes four groups: interior forest, treeless bogs, spruce bogs, and developed areas. The interior forest is predominantly found on well-drained hills east of the Merrill Field airport. Tree species typical of the interior forest include white spruce, paper birch, balsam poplar, black cottonwood, and willow (Viereck and Little, 1972). Shrubs in the interior forest include wild rose, lingonberry, bunchberry, currant, and Labrador tea. Treeless bogs are found in poorly drained, flat areas north, east, and south of the airport where soils are too water saturated to support trees. Primary vegetation types include birch brush, Labrador tea, scrub willow, cotton grass, sphagnum moss, and sedges. Spruce bogs also have water-saturated soils and are found in close proximity to treeless bogs to the east and south of the airport. Typical vegetation types consist of black spruce less than $2 \mathrm{~m}$ in height, sphagnum mosses, sedges, grasses, 


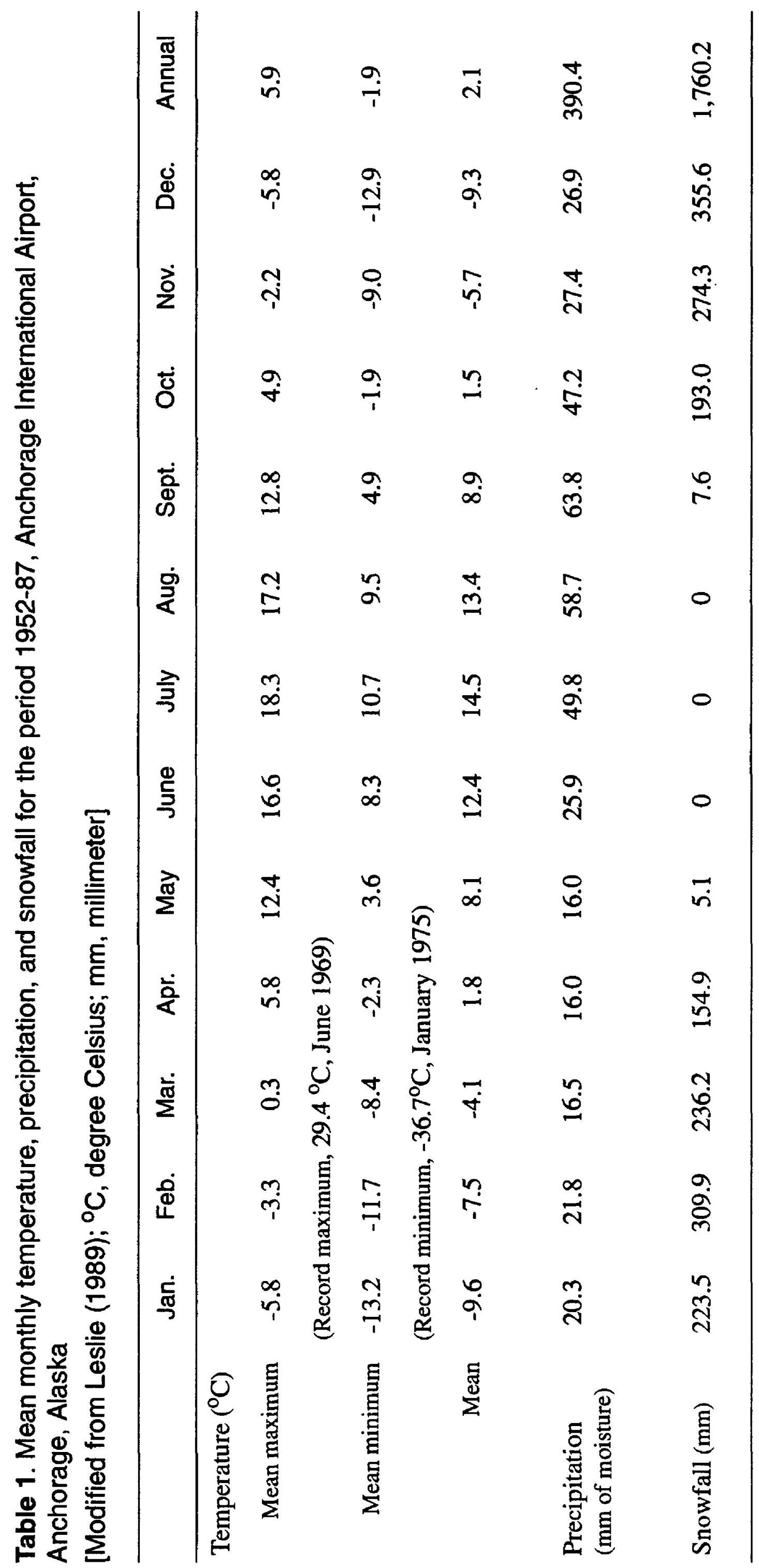


and heath shrubs. Paper birch and white spruce, Labrador tea, prickly rose, willows, bog blueberry, red-fruit bearberry, crowberry and lingonberry are also common in spruce bogs. In developed areas such as the Merrill Field airport and the surrounding urban areas, up to 80 percent of the land surface is covered by asphalt, concrete, buildings, or other impervious surfaces (U.S. Army Corps of Engineers, 1979). Vegetation in these developed areas consist primarily of domestic grasses, shrubs, and trees.

\section{Geology}

The geology of the Anchorage area has been described by Miller and Dobrovolny (1959) and Cederstrom and others (1964). Trainer and Waller (1965) summarized the subsurface deposits in the Anchorage area on the basis of water-well data. The well drillers' logs used in their analyses of the subsurface geology are in the files of the U.S. Geological Survey in Anchorage.

The Anchorage Bowl is underlain by unconsolidated deposits of Quaternary age, weakly lithified deposits of Tertiary age, and metamorphic rocks of Cretaceous/Jurassic age (Clark and others, 1976). The unconsolidated deposits beneath the airport generally consist of interlayered alluvial, glacial, and estuarine sediments. The alluvial and glacial sediments consist of silty sand and sand with some gravel (Schmoll and Dobrovolny, 1972; Freethey, 1976). The estuarine deposits are composed of clayey silt and silty clay with some interbedded sand (Ulery and Updike, 1983). The unconsolidated deposits thicken progressively from less than a few meters on much of the Chugach Mountains to about $300 \mathrm{~m}$ beneath the western part of the Anchorage Bowl (Freethey and Scully, 1980). Underlying the unconsolidated deposits are weakly lithified siltstone, claystone, and sandstone (Schmoll and Barnwell, 1984). Underlying these rocks and exposed in the Chugach Mountains are metamorphic sandstones, siltstones, and volcanic rocks. Glass (1988) provides a map of the depth to bedrock in the Anchorage Bowl. A geologic cross section through Anchorage extending eastward from downtown Anchorage on the shore of Knik Arm to the lower slopes of the Chugach Mountain front is presented by Schmoll and Barnwell (1984). The geologic cross section is a compilation of well logs drilled in the Anchorage area and includes logs of wells that are near Merrill Field airport.

\section{HYDROLOGY}

\section{Surface Water}

Major surface-water bodies near the airport include North Fork of Chester Creek, Chester Creek, Knik Arm of Cook Inlet (fig. 2), and wetlands.

Chester Creek heads in the Chugach Mountains and has a drainage area of about $80 \mathrm{~km}^{2}$ upstream from Westchester Lagoon (fig. 2) (Brabets, 1987). North Fork Chester Creek originates about $1 \mathrm{~km}$ east of the airport and flows southwestward until it intersects with the main stem about $1 \mathrm{~km}$ south of the airport. In the early 1970's, the North Fork Chester Creek was diverted into a corrugated metal conduit through the middle of the Merrill Field landfill (Brunett, 1990). The conduit, which is still in use, leaves the landfill just west of Sitka Street. From the outlet of the conduit, North Fork Chester Creek flows southward in an open ditch to its junction with Chester Creek. The North Fork serves primarily as a storm drain for urbanized areas (Brabets, 1987). From the intersection of North Fork and the main stem, Chester Creek flows approximately $5 \mathrm{~km}$ to Westchester Lagoon and finally into Knik Arm of Cook Inlet. 


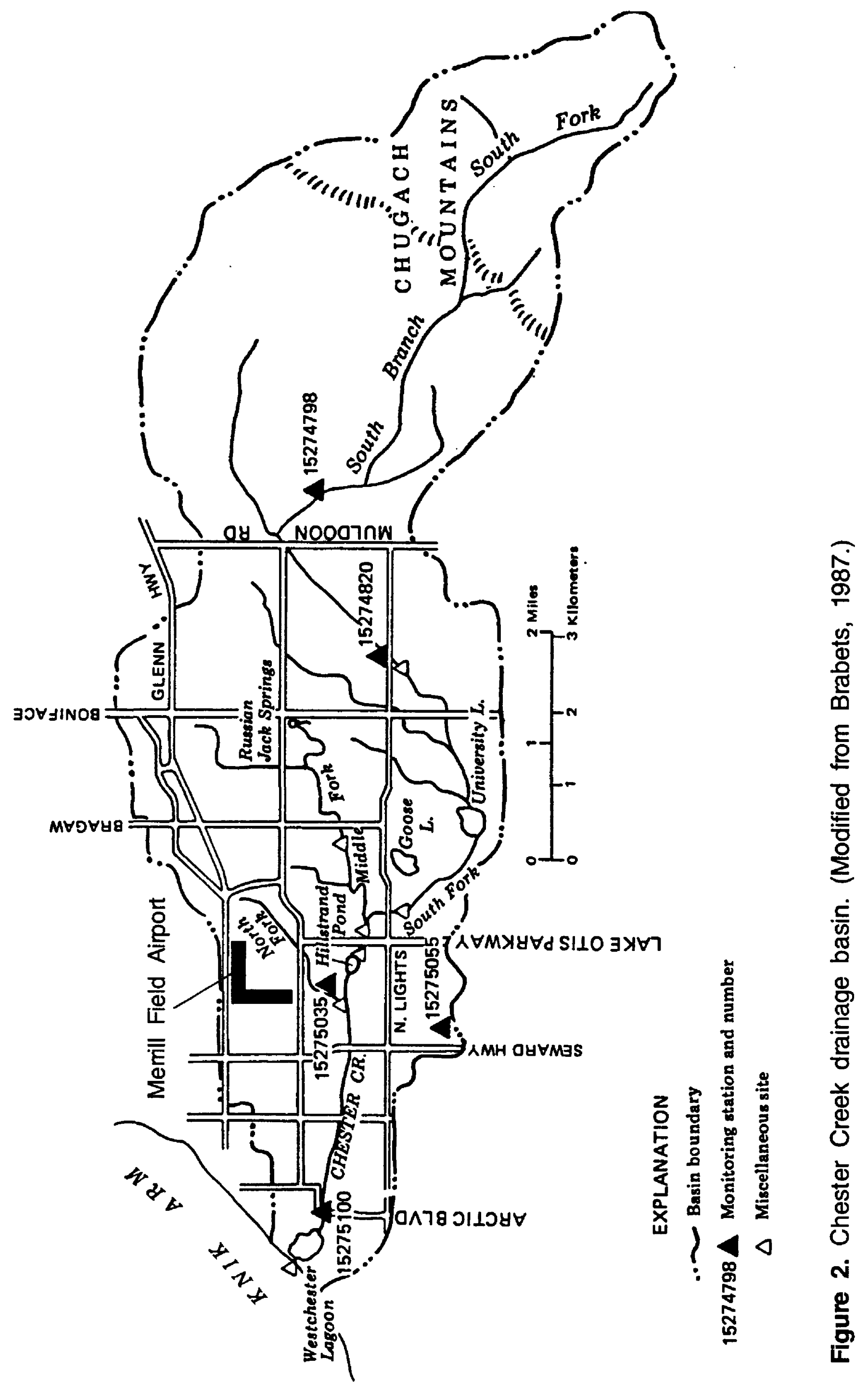


At Arctic Boulevard, mean daily discharges commonly range from about 0.5 to $3.0 \mathrm{~m}^{3} / \mathrm{s}$ (fig. 3). The drainage area upstream from Arctic Boulevard is approximately $70 \mathrm{~km}^{2}$ (Still and Cosby, 1989). The average annual runoff from the Chester Creek basin is about $230 \mathrm{~mm}$, and runoff measured at a station upstream from the mouth of North Fork (station No. 15275035, fig. 2) is about $100 \mathrm{~mm}$ (Brabets, 1987). Runoff from paved areas and other impervious surfaces in the drains upstream from this site are reflected in the hydrograph (fig. 3) as short duration peaks. An impoundment at the mouth of Chester Creek, regulates outflow and maintains the water level of Westchester Lagoon.

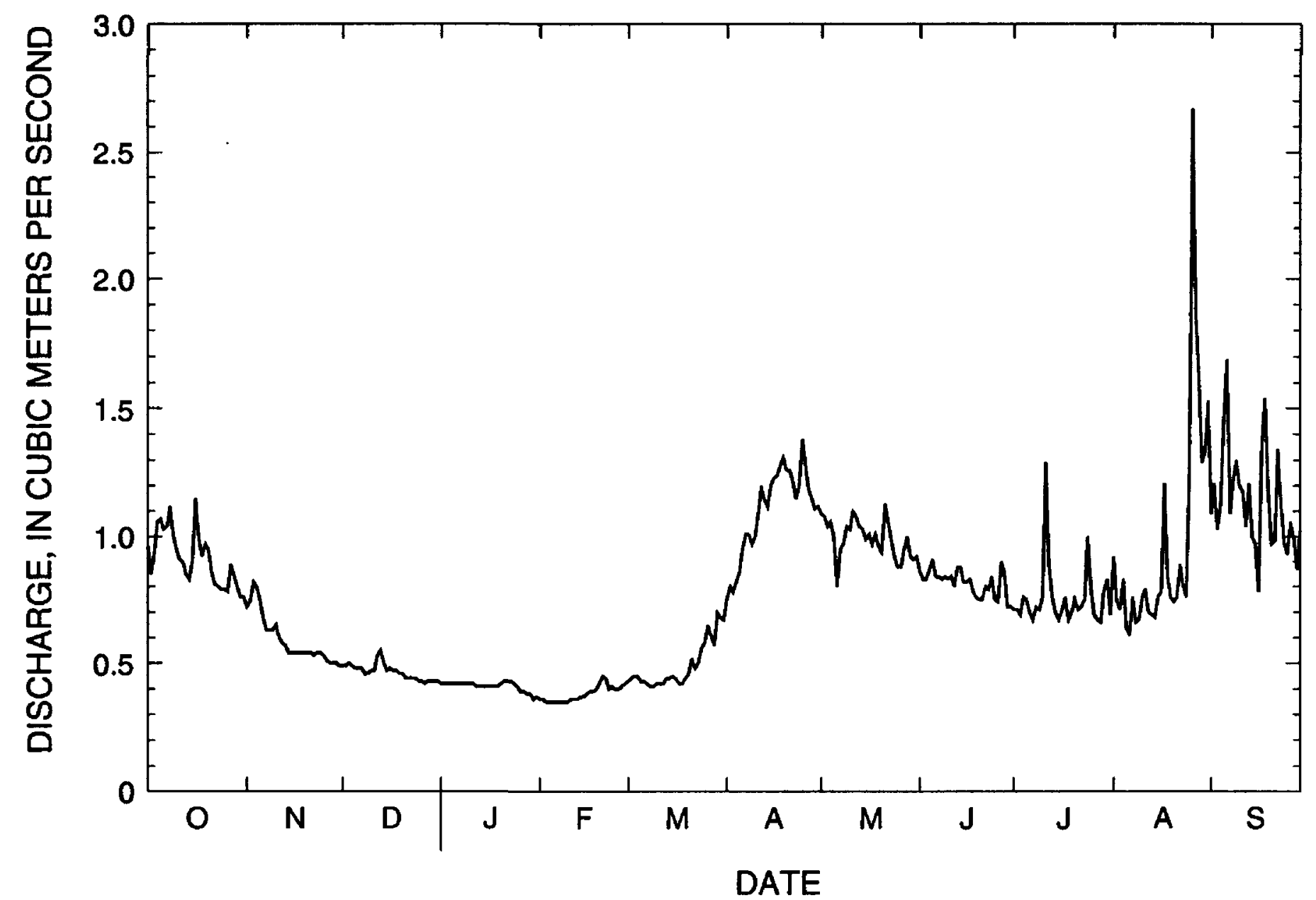

Figure 3. Five-year average, mean daily discharge for Chester Creek at Arctic Boulevard, Anchorage, water years 1989-93.

Runoff from the airport is diverted into a storm-water drainage system and discharges through a single outfall onto the wetlands south of the airport. Prior to the 1991, the landfill buried some of the airport drainage outfall lines. During 1991, the drainage outfall lines that ran under the landfill were abandoned and new outfall routes, serving the airport only, were constructed (Dave Lundeby, Merrill Field airport manager, oral commun., 1994).

In the early 1970's, a leachate collection system (subdrain) was installed in the landfill at the top of a confining clay layer to intercept the leachate and discharge it into the sanitary sewer system. The subdrain routes the leachate to a lift station about $60 \mathrm{~m}$ east of the intersection of East 15th Avenue and Sitka Street. From here, the leachate is pumped into a concrete sanitary sewer line and eventually reaches the Point Woronzof Wastewater Treatment Facility (fig. 1) (Brunett, 1990). 


\section{Surface-Water Quality}

A 1991 study by USGS on the water quality from the airport drainage outfall system, prior to the upgrade, reported evidence that effluent from the landfill entered the drainage system and discharged onto the wetlands (R.L. Rickman, USGS, written commun, 1991). It is believed that the effluent from the landfill no longer enters the upgraded drainage system; however, water-quality tests of the current drainage system have not been done (Dave Lundeby, Merrill Field airport manager, oral commun., 1994).

According to Brunett (1990), North Fork Chester Creek does not appear to undergo significant contamination during its transit through its conduit buried in the landfill, but it was suggested that a small amount of leachate may be entering the creek through leaks in the conduit. Trace amounts of six organic compounds, only one of which is present in the creek above the landfill, were detected in samples from the conduit outlet. The concentrations of iron and manganese, both of which are commonly present in high concentrations in leachate, increase in concentration in Chester Creek downstream from the landfill (Brunett, 1990; appendix 1). Sodium and chloride, however, which are commonly highly concentrated in leachate, were found at lower concentrations downstream from the landfill.

A 2-year water-quality study of the Chester Creek basin during 1982-83 reported that fecal coliform bacteria concentrations near the mouth of Chester Creek exceeded State of Alaska drinking-water regulations during all levels of flow (Brabets, 1987). Lead concentrations exceeded State regulations during rainfall-runoff periods and snowmelt periods. Chloride concentrations exceeded State regulations during snowmelt periods. Water-quality records for North Fork Chester Creek and drains near the Merrill Field airport are shown in appendix 1.

Water from Chester Creek is not used for drinking water, but is used extensively for recreation. No commercial fisheries are present at Chester Creek or Westchester Lagoon, although recreational fishing does occur. Murphy and others (1972) studied the effect of discharging domestic wastewater into Cook Inlet and concluded that because the inlet is a "completely and continuously mixed basin," it is unlikely to become adversely affected by domestic waste water discharge by a population of 10 times that of the 1990 Anchorage census. The study by Murphy and others (1972), however, did not examine the potential effects of hazardous waste discharge into Cook Inlet.

\section{Ground Water}

The sediments in the Anchorage Bowl generally form a freshwater aquifer system consisting of an unconfined aquifer and one or more confined aquifers separated by less permeable layers. Recharge to the aquifers is primarily from infiltration of precipitation and seepage from streams. Patrick and others (1989) present an analysis of the distribution and relative contribution of recharge to the aquifer system. An estimated 280 to 380 million L/d is naturally lost from the ground-water system in the Anchorage Bowl from evaporation, plant transpiration, and seepage (Glass, 1987).

Patrick and others (1989, fig. 4) provide a generalized map illustrating the variation in thickness of the unconfined aquifer throughout the Anchorage Bowl. The thickness of the unconfined aquifer in the vicinity of the Merrill Field airport and landfill ranges from $0 \mathrm{~m}$ to about $15 \mathrm{~m}$. The depth to ground water at the Merrill Field landfill is generally less than $3 \mathrm{~m}$ (Freethey and others, 1974). North of the landfill, beneath much of the airport where the topography is slightly higher, the depth to ground water is generally greater than $6 \mathrm{~m}$. The surficial deposits near the airport and landfill are considered highly to very highly permeable relative to other soils in the Anchorage area (Freethey, 1976). Hydraulic conductivity is the capacity of geologic materials to transmit water. 
The rate at which water can flow laterally through geologic materials is proportional to the horizontal hydraulic conductivity. On the basis of local lithology and specific capacity data, Patrick and others (1989) estimated that horizontal hydraulic conductivity of the unconfined aquifer in the Anchorage Bowl ranged from about 1 to $46 \mathrm{~m} / \mathrm{d}$. The horizontal hydraulic conductivity of the sediments of the unconfined aquifer in the vicinity of Merrill Field was estimated to be about $5 \mathrm{~m} / \mathrm{d}$ (Patrick and others, 1989).

The confined aquifer underlying the Anchorage Bowl generally thickens from east to west. The thickness of the confined aquifer ranges from $0 \mathrm{~m}$ near the mountain front to more than $330 \mathrm{~m}$ in the western part of the Anchorage Bowl. Adjacent to the Chugach Mountains, the confined and unconfined aquifers share a common source of recharge because the confining sediments are discontinuous. Patrick and others $(1989$, fig. 6$)$ provide a generalized map illustrating the variation in thickness of the confined aquifer. The thickness of the confined aquifer in the vicinity of the airport ranges from about 150 to $180 \mathrm{~m}$. Patrick and others (1989, fig. 13) estimated that the horizontal hydraulic conductivity of the sediments of the confined aquifer in the Anchorage Bowl ranged from 0.9 to $21 \mathrm{~m} / \mathrm{d}$. In the vicinity of the airport, the hydraulic conductivity of the sediments of the confined aquifer was approximately $3 \mathrm{~m} / \mathrm{d}$.

The confining layers are variable in lithology and thickness, which results in local differences in their ability to retard movement of water from one aquifer to another. The main confining layer in the central part of the Anchorage Bowl is the estuarine deposits-an areally extensive layer of silty clay and clayey silt with some interbedded lenses of sand. In the western and eastern parts of the Anchorage Bowl, confining layers generally consist of coarser till or till-like deposits and may be discontinuous or absent. The confining layer ranges in thickness from 0 to about $80 \mathrm{~m}$ beneath the Anchorage Bowl and from 15 to $30 \mathrm{~m}$ beneath the airport (Patrick and others, 1989, fig. 5). The vertical hydraulic conductivity of the confining layers was estimated to be approximately $0.00003 \mathrm{~m} / \mathrm{d}$ where the confining layers are predominantly clay and $0.3 \mathrm{~m} / \mathrm{d}$ along the mountain front area where the confining layers are discontinuous.

Nelson (1982) estimated that the vertical hydraulic conductivity of the confining unit was $0.003 \mathrm{~m} / \mathrm{d}$ for gravelly sand and silt, and $0.00006 \mathrm{~m} / \mathrm{d}$ for silty clay. Some of the refuse at the landfill has been buried below the water table, creating an environment in which the refuse is continuously leached. Nelson (1982) estimated that it would take many tens of years for minor amounts of pollutants to reach the confined aquifer and about 300 years for water with the composition of the leachate to reach the confined aquifer, had municipal pumping continued at its 1980 rate. However, the Municipality has significantly reduced ground-water pumping since the Eklutna water system began delivering water to Anchorage. As a result of the reduced ground-water pumping, vertical ground-water gradients near Merrill Field are upward. Upward gradients will prevent downward migration of soluble contaminants (Gordon Nelson, U.S. Geological Survey, oral commun., 1995).

A mathematical simulation of ground-water flow by Patrick and others (1989) indicated that the regional ground-water flow direction in the Anchorage Bowl is westward from the Chugach Mountains towards Cook Inlet. A water-table contour map based on measured water levels in the unconfined aquifer show's that locally, ground water at Merrill Field airport flows to the southwest towards Chester Creek (Dearborn and Freethey, 1974). A study of the lateral migration of contaminants in the shallow, unconfined aquifer near the landfill also shows that ground-water generally flows from the Merrill Field airport and landfill areas southwestward towards Chester Creek (fig. 4). A series of wells drilled in the landfill and in wetlands south of the landfill provide information (table 2) on the ground-water flow direction and subsurface geology of the area (fig. 4). 


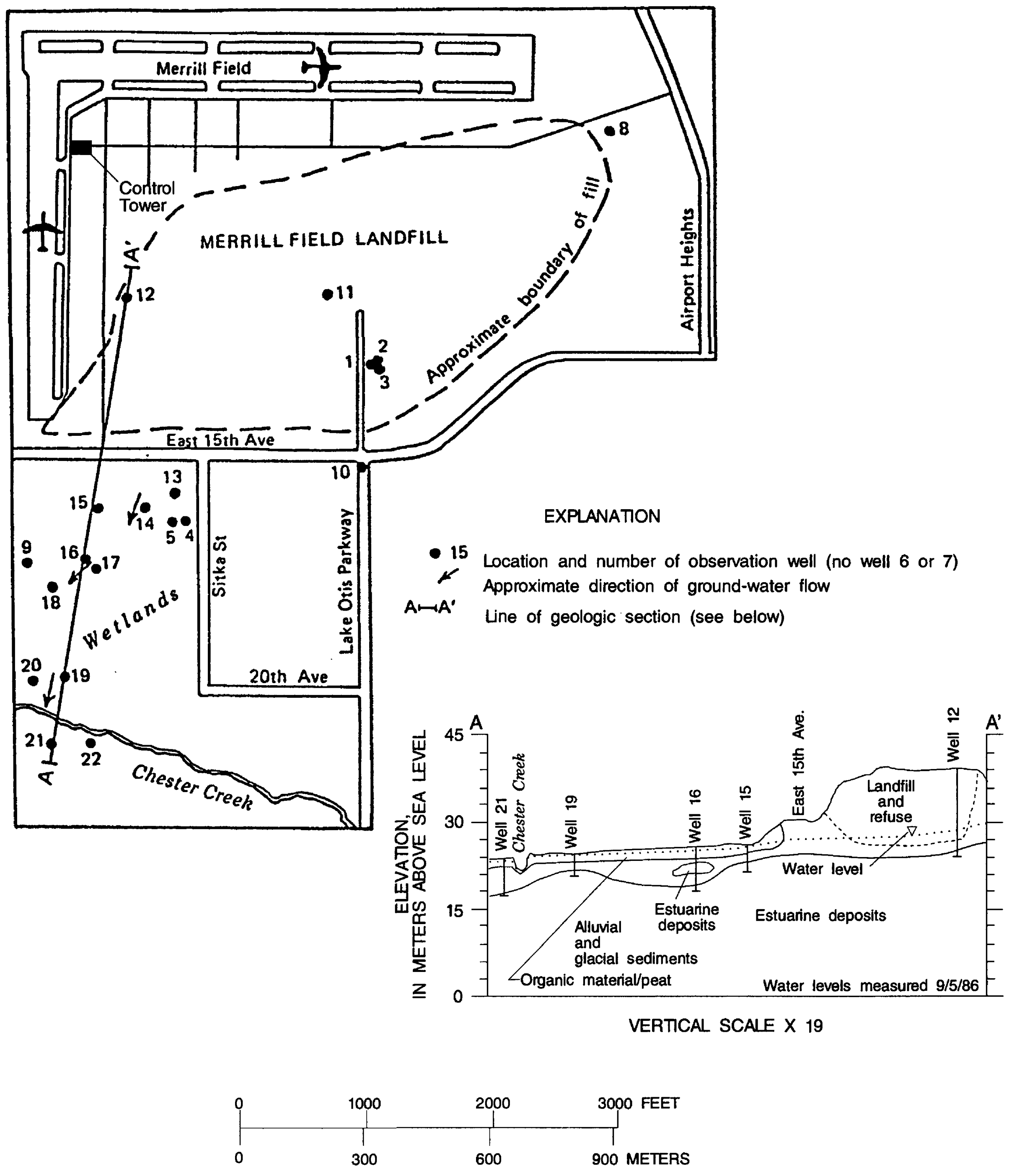

Figure 4. Locations of observation wells, and geologic section through wetlands and the landfill. (See figure 1 for location; modified from Brunett, 1990.) 


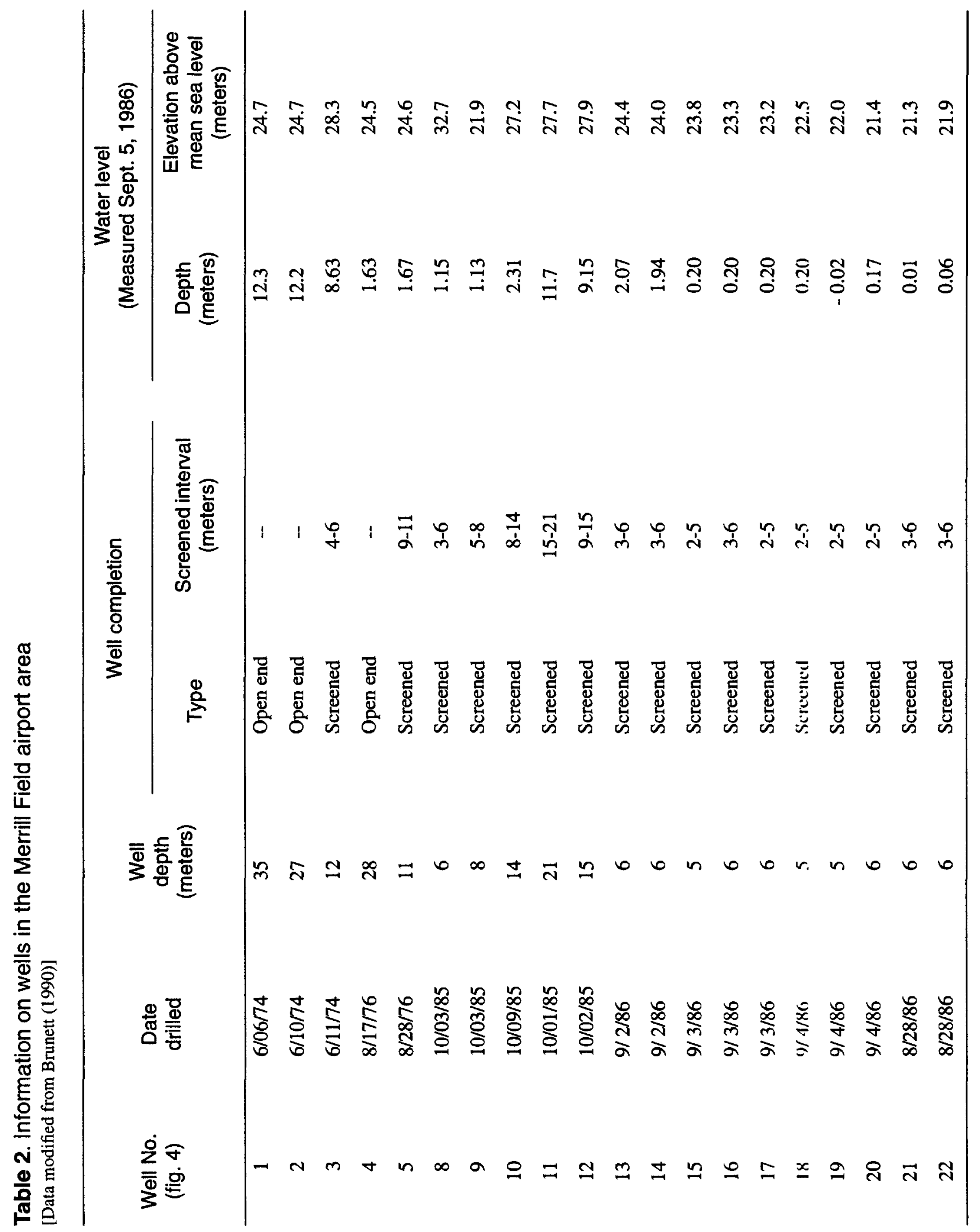




\section{Ground-Water Quality}

Water-quality tests of samples taken from wells downgradient from the landfill near the airport indicated that minor amounts of contaminants have reached the wetlands as far south as Chester Creek (Brunett, 1990). Wells from which samples had concentrations of some constituents that exceeded U.S. Environmental Protection Agency (1993) maximum contaminant levels (MCL) for drinking water are shown in table 3.

Table 3. Wells near Merrill Field airport in which water sample concentrations exceeded drinkingwater regulations

[Data modified from Brunett (1990); $\mu \mathrm{g} / \mathrm{L}$, microgram per liter; USEPA, U.S. Environmental Protection Agency;

MCL, maximum contaminant level]

\begin{tabular}{llcc}
\hline \multicolumn{1}{c}{ Constituent } & \multicolumn{1}{c}{$\begin{array}{c}\text { Wells in which observed } \\
\text { (fig. 4) }\end{array}$} & $\begin{array}{c}\text { USEPA (1993) MCL for } \\
\text { drinking water } \\
(\mu \mathrm{g} / \mathrm{L})\end{array}$ & $\begin{array}{c}\text { Maximum sample } \\
\text { concentration } \\
\text { detected } \\
(\mu \mathrm{g} / \mathrm{L})\end{array}$ \\
\hline Benzene & 3,12 & 5.0 & 20 \\
Trichloroethylene & 12 & 5.0 & 8.0 \\
Vinyl chloride & $3,11,12,14$ & 2.0 & 53 \\
& & & 130 \\
Arsenic, total & $1,2,5$ & 50 & 350 \\
Chromium, total & 8,9 & 100 & 500,000 \\
Iron, total & All, except $1,4,21$ & 300 & 300 \\
Lead, total & $3,10,11,22$ & 50 & 84,000 \\
Manganese, total & All & 50 & 1,000 \\
Nickel. total & $8,9,10,11,12,15,17,18,22$ & 100 & \\
\hline
\end{tabular}

\section{Drinking Water}

\section{Present Drinking-Water Supplies}

Most of the water used for domestic, industrial, and commercial uses in the airport area is from a public water-distribution system; relatively few people utilize private water wells. The water system, operated by the Anchorage Water and Wastewater Utility (AWWU), is supplied from two surface water sources-Eklutna Lake and Ship Creek (fig. 1)-and from wells located throughout the city (AWWU, 1993). Water from Ship Creek, is withdrawn at a dam located at the mouth of a canyon on the edge of the Chugach Mountains. In 1992, Ship Creek supplied an average 47.3 million L/d and has a production capacity of $90.8 \mathrm{million} \mathrm{L} / \mathrm{d}$. Eklutna Lake, located approximately $24 \mathrm{~km}$ northeast of downtown Anchorage, supplied approximately $34.4 \mathrm{million} \mathrm{L/d}$ in 1992 and has a production capacity of 133 million L/d (AWWU, 1993). The Municipality of 
Anchorage also pumps water from 19 wells: 1 well is pumped continuously, 12 wells are used intermittently, and 6 are pumped for only maintenance purposes and are available if needed. In 1992, ground-water sources provided an average of 8.2 million $\mathrm{L} / \mathrm{d}$ to the city's water system but have a production capacity of 89.3 million $\mathrm{L} / \mathrm{d}$. Total water withdrawals for the Municipality of Anchorage in 1990 represent about 25 percent of the combined production capacity of the surface- and ground-water sources. Pumpage data for wells in the Anchorage area during 1990 is summarized by Petrik (1991).

Most private wells used for water supply in the Merrill Field area were installed during a period of accelerated residential development before municipal services were extended into these locations. Records in the USGS Ground Water Site Inventory (GWSI) database for wells within about a 1-km radius from Merrill Field airport control tower are shown in appendix 2 . A recent survey, however, has not been conducted to determine how many of the wells in the area are currently in use.

\section{Quality of Present Supplies}

Surface water is flocculated, filtered, chlorinated, and fluoridated before it is distributed; ground water is chlorinated and fluoridated (AWWU, 1993). The AWWU Annual Water Quality Report for 1992 (AWWU, 1993) contains water-quality data for surface and ground-water supplies and indicates both met the drinking-water regulations established by State of Alaska.

\section{Alternative Drinking-Water Sources}

If the aquifer(s) become contaminated, new wells could be drilled outside the affected area or the municipal water system could be made available as an alternative water supply. The AWWU system has the capacity to increase production and a water distribution system already exists in much of the area in and around the Merrill Field airport area.

\section{SUMMARY}

The Federal Aviation Administration operates airway support and navigation facilities on Merrill Field in an urban area east of downtown Anchorage. A solid-waste landfill formerly occupied the eastern and southern sides of the airport. Water-quality records from ground-water drains and nearby surface water reflect high concentrations of some constituents commonly associated with landfill leachate. Most residential, commercial, and industrial consumers in the area obtain water from a municipal water-supply system. 


\section{REFERENCES CITED}

Alaska Department of Community and Regional Affairs, 1993, Community profile database for Anchorage, Alaska: Alaska Department of Community and Regional Affairs, 19 p.

Anchorage Water and Wastewater Utility, 1993, Annual water quality report-1992: Municipality of Anchorage, Anchorage Water and Wastewater Utility, 9 p.

Brabets, T.P., 1987, Quantity and quality of urban runoff from the Chester Creek basin, Anchorage, Alaska: U.S. Geological Survey Water-Resources Investigations Report 86-4312, 58 p.

Brunett, J.O., 1990, Lateral movement of contaminated ground water from Merrill Field landfill, Anchorage, Alaska: U.S. Geological Survey Open-File Report 89-624, 20 p.

Cederstrom, D.J., Trainer, F.W., and Waller, R.M., 1964, Geology and ground-water resources of the Anchorage area, Alaska: U.S. Geological Survey Water-Supply Paper 1773, 108 p.

Clark, S.H.B., Yount, M.E., and Bartsch, S.R., 1976, Reconnaissance geologic map and geochemical analysis of stream-sediment and rock samples of the Anchorage A-7 and A-8 quadrangles, Alaska: U.S. Geological Survey Miscellaneous Field Studies Map MF-765, 3 sheets.

Dearborn, L.L., and Freethey, G.W., 1974, Water-table contour map, Anchorage area, Alaska: U.S. Geological Survey Open-File Report 1974, 1 sheet.

Ecology and Environment, Inc., 1994, Environmental compliance investigation report for Merrill Field FAA station, Anchorage, Alaska: Anchorage [Draft report available from Federal Aviation Administration, Alaskan Region], variously paged.

Freethey, G.W., 1976, Relative permeability of surficial geologic materials, Anchorage and vicinity, Alaska: U.S. Geological Survey Miscellaneous Investigations Map I-787-F, 1 sheet.

Freethey, G.W., Reeder, J.W., and Barnwell, W.W., 1974, Map showing depth to water, Anchorage area, Alaska: U.S. Geological Survey Open-File Report, 1 sheet.

Freethey, G.W., and Scully, D.R., 1980, Water resources of the Cook Inlet Basin: U.S. Geological Survey Hydrologic Investigations Atlas HA-620, 4 sheets.

Glass, R.L., 1987, Ground-water levels in Anchorage, Alaska: U.S. Geological Survey Open-File Report 87-548, 15 p. +1 map.

1988, Map showing depth to bedrock, Anchorage, Alaska: U.S. Geological Survey Open-File Report 88-198, 1 sheet.

Hartman, C.W., and Johnson, P.R., 1984, Environmental atlas of Alaska: University of Alaska Fairbanks, Institute of Water Resources/Engineering Experiment Station, 95 p.

Leslie, L.D., 1989, Alaska climate summaries (2d ed.): University of Alaska, Anchorage, Arctic Environmental Information and Data Center, Alaska Climate Center Technical Note 5.

Miller, R.D., and Dobrovolny, E., 1959, Surficial geology of Anchorage and vicinity, Alaska: U.S. Geological Survey Bulletin 1093, $128 \mathrm{p}$.

Murphy, R.S., Carlson, R.F., Nyquist, D., and Britch, R., 1972, Effect of waste discharges into a silt-laden estuary--A case study of Cook Inlet, Alaska: University of Alaska, Institute of Water Resources Publication No. IWR 26, $25 \mathrm{p}$.

Nelson, G.L., 1982, Vertical movement of ground water under the Merrill Field landfill, Anchorage, Alaska: U.S. Geological Survey Open-File Report 82-1016, 24 p.

Patrick, L.D., Brabets,T.P., and Glass, R.L., 1989, Simulation of ground-water flow at Anchorage, Alaska, 1955-83: U.S. Geological Survey Water-Resources Investigations Report 88-4139, 41 p.

Petrik, W.A., 1991, Estimated use of water in the United States 1990-Selected large Alaskan public water suppliers, documentation and data forms: Alaska Division of Geological and Geophysical Surveys Public-Data File 91-26, $179 \mathrm{p}$. 
Schmoll, H.R., and Barnwell, W.W., 1984, East-west geologic cross section along the DeBarr Line, Anchorage, Alaska: U.S. Geological Survey Open-File Report 84-791, 11 p., 1 sheet, scale 1:25,000.

Schmoll, H.R., and Dobrovolny, Ernest, 1972, Generalized geologic map of Anchorage and vicinity, Alaska: U.S. Geological Survey Miscellaneous Geologic Investigations Map I-787-A, scale 1:24,000, 1 sheet.

Selkregg, L.L., Buck, E.H., Buffler, R.T., Coté, O.E., Evans, C.D., and Fisk, S.G., 1972, Environmental atlas of the Greater Anchorage Area Borough, Alaska: University of Alaska, Anchorage, Arctic Environmental Information and Data Center, Resource and Science Services, Alaska Sea Grant Program Report No. 72-4, 105 p.

Still, P.J., and Cosby, J.M., 1989, Alaska index-Streamflow, lake levels, and water-quality records to September 30, 1988: U:S. Geological Survey Open-File Report 89-269, 189 p.

Trainer, F.W., and Waller, R.M., 1965, Subsurface stratigraphy of glacial drift at Anchorage, Alaska: U.S. Geological Survey Professional Paper 525-D, p. D167-D174.

Ulery, C.A., and Updike, R.G., 1983, Subsurface structure of the cohesive facies of the Bootlegger Cove formation, southwest Anchorage: Alaska Division of Geological and Geophysical Surveys Professional Report PR-84, 5 p.

U.S. Army Corps of Engineers, 1979, Soils of the Anchorage area, Alaska: U.S. Soil Conservation Service, Metropolitan Anchorage Urban Study, Volume 7, 124 p.

U.S. Environmental Protection Agency, 1993, Drinking water regulations and health advisories: U.S. Environmental Protection Agency report, $11 \mathrm{p}$.

Viereck, L.A., and Little, E.L. Jr., 1972, Alaska trees and shrubs: U.S. Department of Agriculture Handbook No. 410, $265 \mathrm{p}$. 


\section{APPENDIX 1}

Water-quality records for North Fork Chester Creek and drains near the Merrill Field airport 


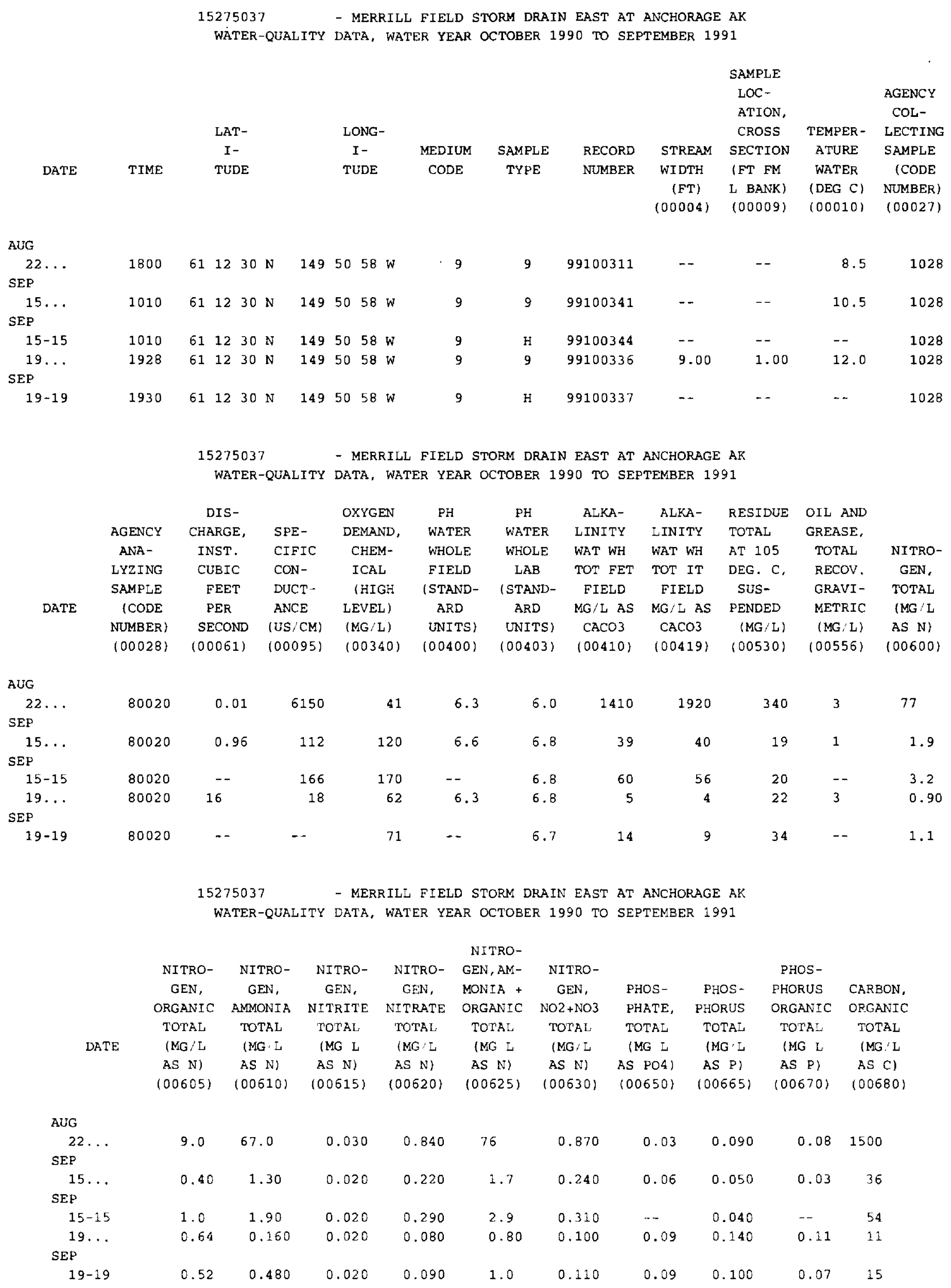




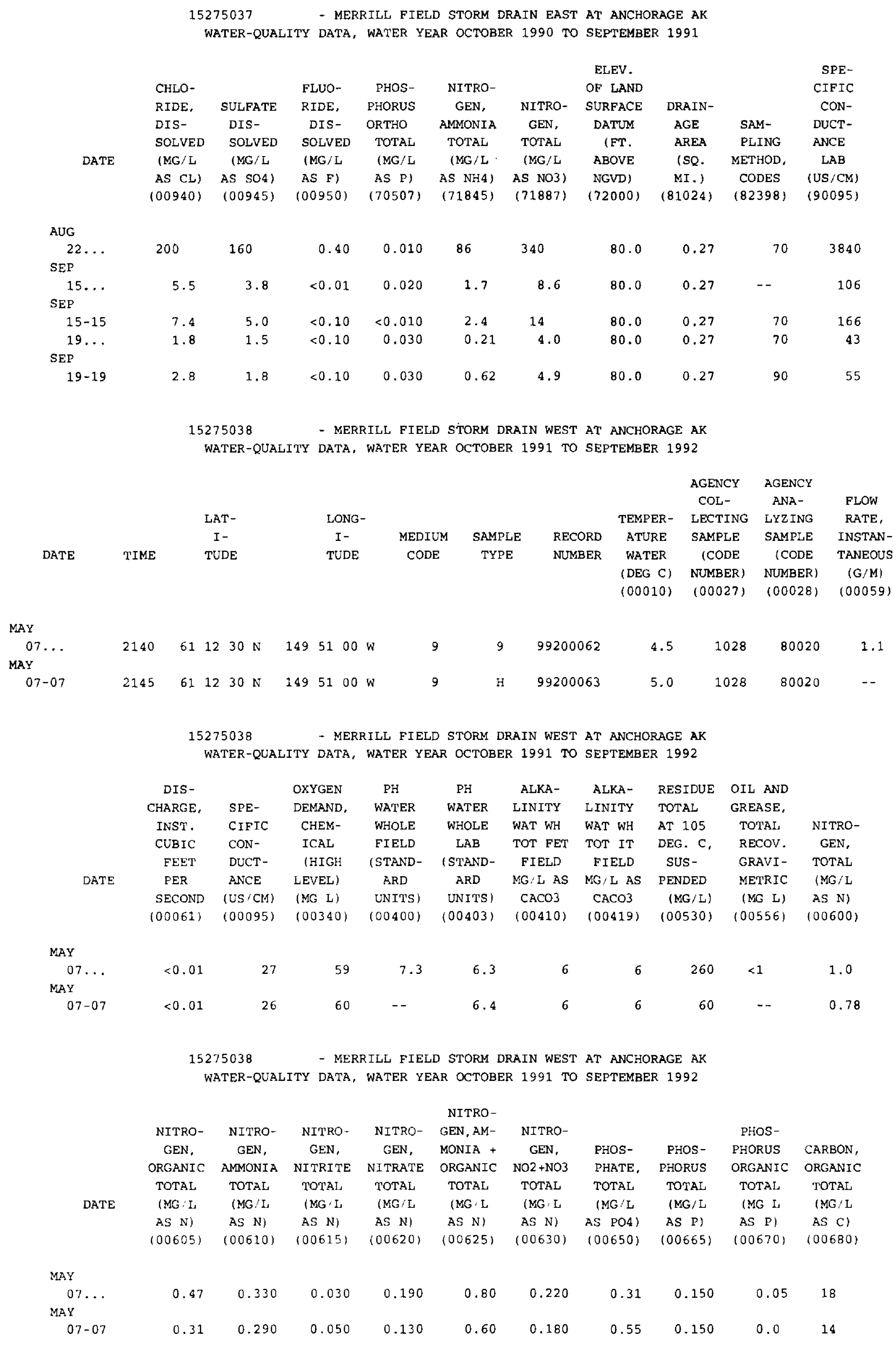




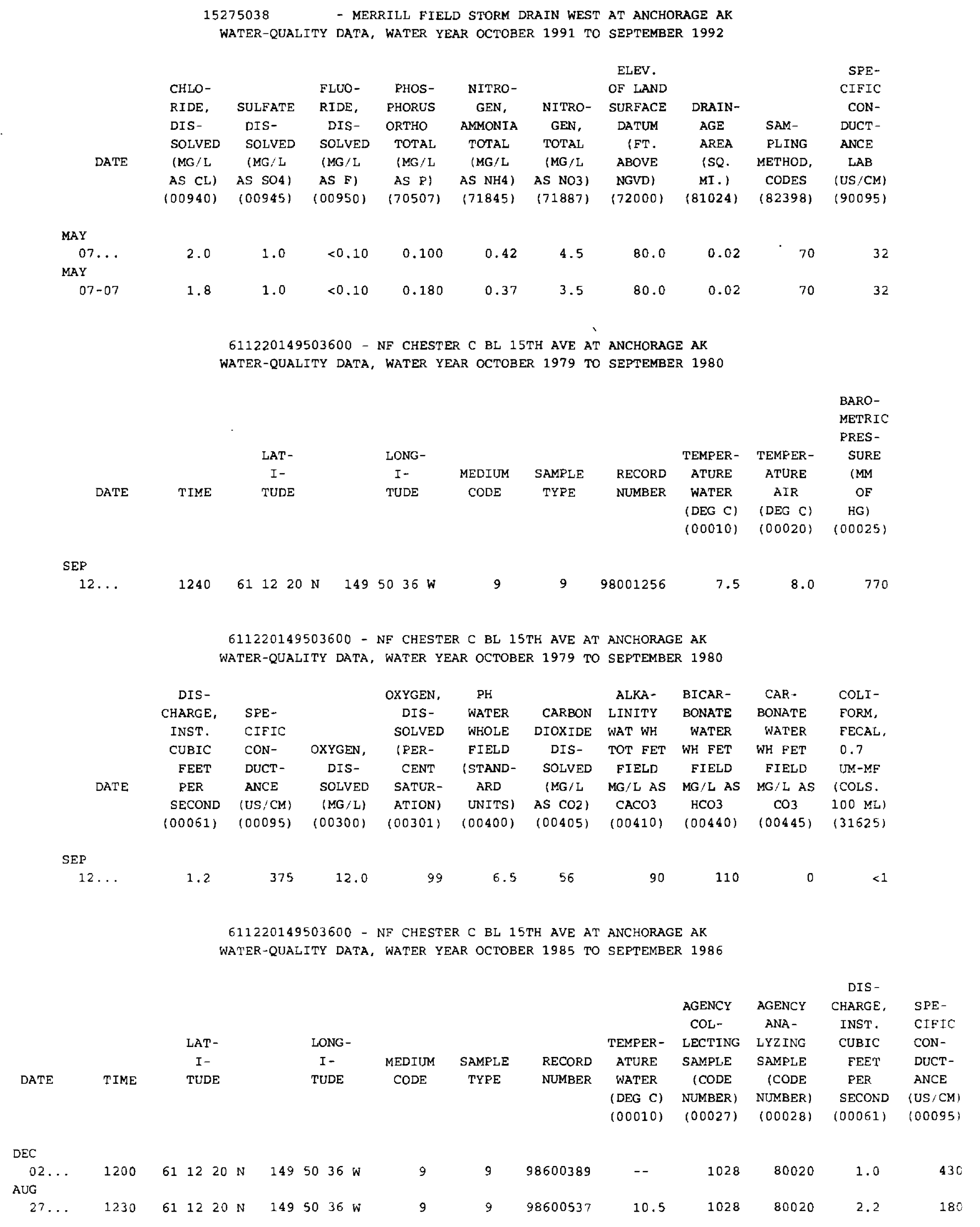


611220149503600 - NF CHESTER C BL 15TH AVE AT ANCHORAGE AK

WATER-QUALITY DATA, WATER YEAR OCTOBER 1985 TO SEPTEMBER 1986

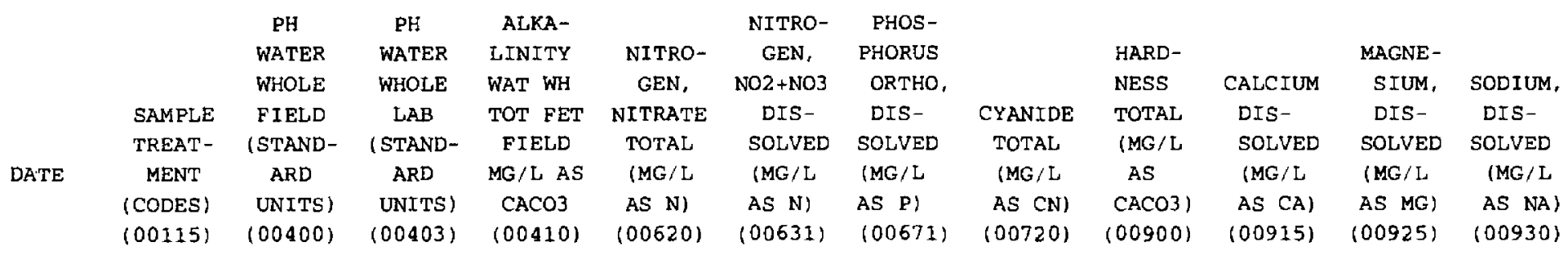

\begin{tabular}{|c|c|c|c|c|c|c|c|c|c|c|c|c|}
\hline 02 & & & & & & & & & & & & \\
\hline $02 \ldots$ & 1 & -- & 8.0 & 126 & 1.90 & 1.90 & $<0.010$ & $<0.010$ & 190 & 53 & 15 & 15 \\
\hline \multicolumn{13}{|l|}{ AUG } \\
\hline $27 \ldots$ & 1 & 5.7 & 6.7 & 59 & 0.650 & 0.650 & $<0.010$ & -- & 80 & 23 & 5.4 & 8.3 \\
\hline
\end{tabular}

$6 I I 220149503600$ - NF CHESTER C BL 15TH AVE AT ANCHORAGE AK WATER-QUALITY DATA, WATER YEAR OCTOBER 1985 TO SEPTEMBER 1986

\begin{tabular}{|c|c|c|c|c|c|c|c|c|c|c|c|c|}
\hline & $\begin{array}{c}\text { SODIUM } \\
\text { AD- }\end{array}$ & & $\begin{array}{l}\text { POTAS- } \\
\text { SIUM, }\end{array}$ & $\begin{array}{l}\text { CHLO- } \\
\text { RIDE. }\end{array}$ & SULFATE & $\begin{array}{l}\text { FLUO- } \\
\text { RIDE, }\end{array}$ & $\begin{array}{l}\text { SILICA, } \\
\text { DIS- }\end{array}$ & & $\begin{array}{l}\text { BERYL- } \\
\text { LIUM, } \\
\text { TOTAL }\end{array}$ & $\begin{array}{l}\text { CADMIUM } \\
\text { TOTAL }\end{array}$ & $\begin{array}{l}\text { CHRO- } \\
\text { MIUM, } \\
\text { TOTAL }\end{array}$ & $\begin{array}{c}\text { COPPER, } \\
\text { TOTAL }\end{array}$ \\
\hline & SORP- & & DIS- & DIS- & DIS- & DIS- & SOLVED & ARSENIC & RECOV- & RECOV- & RECOV - & $\begin{array}{l}\text { RECOV- } \\
\text { ERABLE }\end{array}$ \\
\hline
\end{tabular}

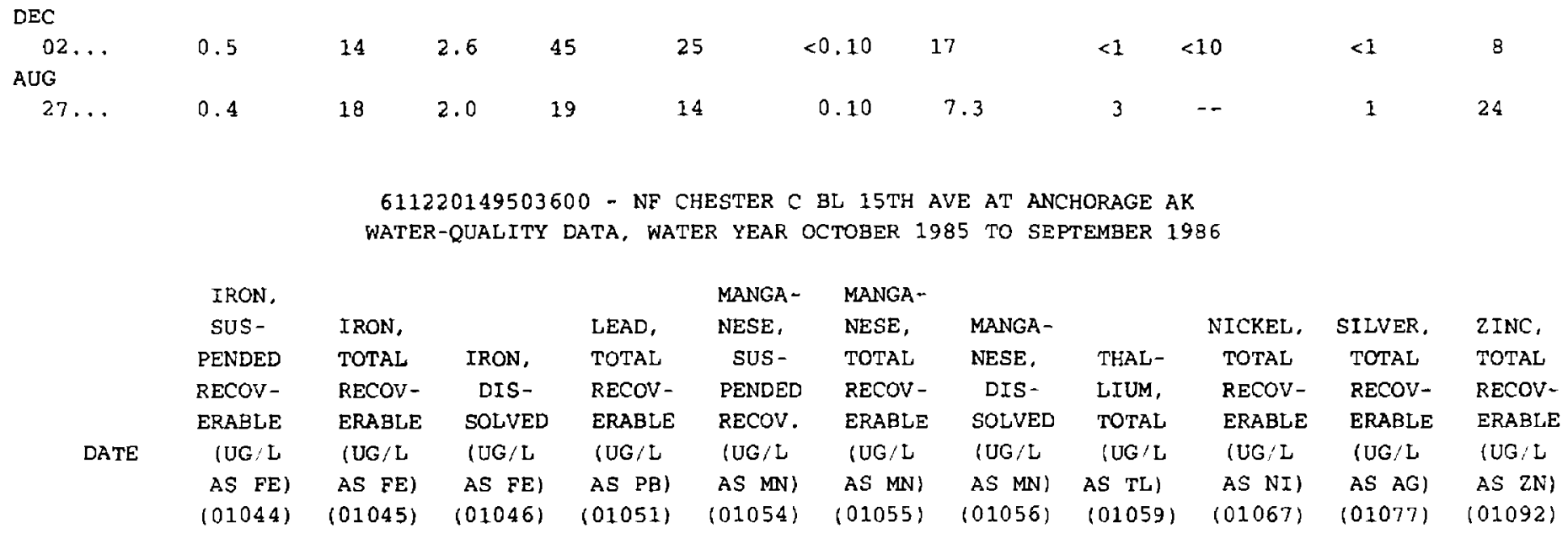

\begin{tabular}{|c|c|c|c|c|c|c|c|c|c|c|c|}
\hline $02 \ldots$ & & 5300 & 5800 & $<1$ & 30 & 270 & 240 & $<1$ & 1 & $<1$ & 50 \\
\hline & & & & & & & & & & & \\
\hline $27 \ldots$ & -- & 11000 & 1300 & 60 & -- & 350 & 170 & -- & 18 & -- & 210 \\
\hline
\end{tabular}

611220149503600 - NF CHESTER C BL 15TH AVE AT ANCHORAGE AK WATER-QUALITY DATA, WATER YEAR OCTOBER 1985 TO SEPTEMBER 1986

\begin{tabular}{|c|c|c|c|c|c|c|c|c|c|c|}
\hline ANTT - & SELE- & $\begin{array}{c}\text { DI- } \\
\text { CHLORO- }\end{array}$ & $\begin{array}{r}\text { CARBON- } \\
\text { TETRA- }\end{array}$ & $1,2-\mathrm{DI}-$ & & $\begin{array}{c}\text { CHLORO- } \\
\text { DI - }\end{array}$ & & & & ACE- \\
\hline MONY, & NIUM, & BROMO- & CHLO- & CHLORO- & BROMO- & BROMO - & CHLORO- & & & NAPHTH \\
\hline TOTAL & TOTAL & METHANE & RIDE & ETHANE & FORM & METHANE & FORM & TOLUENE & BENZENE & YLENE \\
\hline $\begin{array}{l}\text { (UG, L } \\
\text { AS SB) }\end{array}$ & $\begin{array}{l}\text { (UG/L } \\
\text { AS SE) }\end{array}$ & $\begin{array}{l}\text { TOTAL } \\
\text { (UG/L) }\end{array}$ & $\begin{array}{l}\text { TOTAL } \\
\text { (UG/L) }\end{array}$ & $\begin{array}{l}\text { TOTAL } \\
\text { (UG L) }\end{array}$ & $\begin{array}{l}\text { TOTAL } \\
\text { (UG/L) }\end{array}$ & $\begin{array}{l}\text { TOTAL } \\
\text { (UG/L) }\end{array}$ & $\begin{array}{l}\text { TOTAL } \\
\text { (UG/L) }\end{array}$ & $\begin{array}{l}\text { TOTAL } \\
\text { (UG L L) }\end{array}$ & $\begin{array}{l}\text { TOTAL } \\
\text { (UG/L) }\end{array}$ & $\begin{array}{l}\text { TOTAL } \\
\text { (UG L) }\end{array}$ \\
\hline$(01097)$ & $(01147)$ & (3210I) & $(32102)$ & $(32103)$ & $(32104)$ & $(32105)$ & $(32106)$ & $(34010)$ & $(34030)$ & $(34200)$ \\
\hline
\end{tabular}

\begin{tabular}{|c|c|c|c|c|c|c|c|c|c|c|c|}
\hline \multicolumn{12}{|l|}{$\mathrm{DEC}$} \\
\hline $02 \ldots$ & $<1$ & $<1$ & $<3.0$ & $<3.0$ & $<3.0$ & $<3.0$ & $<3.0$ & $<3.0$ & 5.0 & $<3.0$ & $<5.0$ \\
\hline \multicolumn{12}{|l|}{ AUG } \\
\hline $27 \ldots$ & 1 & -- & $<0.2$ & $<0.2$ & $<0.2$ & $<0.2$ & $<0.2$ & $<0.2$ & $<0.2$ & $<0.2$ & -- \\
\hline
\end{tabular}


611220149503600 - NF CHESTER $ᄃ \equiv$ 15TH AVE AT ANCHORAGE AK

WATER-QUALITY DATA, WATER YEAR ZCTOBER 1985 TO SEPTEMBER 1980

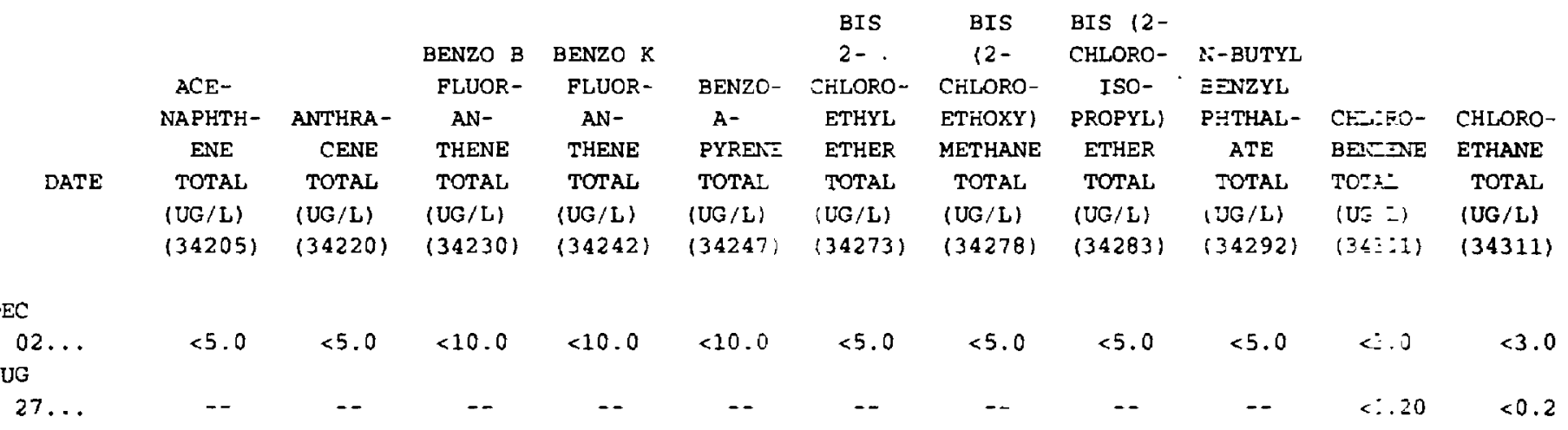

611220149503600 - NF CHESTER $C \equiv$ 15TH AVE AT ANCHORAGE AK WATER-QUALITY DATA, WATER YEAF STOBER 1985 TO SEPTEMBER 1986

\begin{tabular}{|c|c|c|c|c|c|c|c|c|c|c|c|}
\hline & & & & & & & HEXA- & & & & \\
\hline & & & DI - & & & & CHLORO- & & IXDENO & & \\
\hline & $\begin{array}{l}\text { CHRY- } \\
\text { SENE }\end{array}$ & $\begin{array}{c}\text { DIETHYL } \\
\text { PHTHAL- } \\
\text { ATE }\end{array}$ & $\begin{array}{l}\text { METHYL } \\
\text { PHTHAL- } \\
\text { ATE }\end{array}$ & $\begin{array}{l}\text { ETHYL- } \\
\text { BENZENE }\end{array}$ & $\begin{array}{l}\text { FLUOR- } \\
\text { ANTHENE }\end{array}$ & $\begin{array}{c}\text { ELUOR- } \\
\text { ENE }\end{array}$ & $\begin{array}{l}\text { CYCLO- } \\
\text { PENT- } \\
\text { ADIENE }\end{array}$ & $\begin{array}{l}\text { HEXA- } \\
\text { CHLORO- } \\
\text { ETHANE }\end{array}$ & $\begin{array}{c}12,2,3- \\
C D) \\
\text { F:RENE }\end{array}$ & $\begin{array}{c}I B:- \\
\text { PHEE-NE }\end{array}$ & $\begin{array}{l}\text { METHYL- } \\
\text { BROMIDE }\end{array}$ \\
\hline \multirow[t]{3}{*}{ DATE } & TOTAL & TOTAL & TOTAL & TOTAL & TOTAL & TOTAL & TOTAL & TOTAL & =OTAL & TETI & TOTAL \\
\hline & (UG/L) & (UG / L) & (UG/L) & $\{U G / L\}$ & (UG/L) & $(\tilde{G} / L)$ & (UG/L) & (UG/L) & (ZG L) & 何 $=-1$ & $(U G / L)$ \\
\hline & $(34320)$ & $(34336)$ & $(34341)$ & $\{34371\}$ & 134376 & $(34381)$ & $(34386)$ & $(34396)$ & $(\equiv 4403)$ & $(3 \leq \pm: 5)$ & $(34413)$ \\
\hline \multicolumn{12}{|l|}{ DEC } \\
\hline $02 \ldots$ & $<10.0$ & $<5.0$ & $<5.0$ & $<3.0$ & $<5.0$ & $<5.0$ & $<5.0$ & $<5.0$ & $<10.0$ & $<\equiv .3$ & $<3.0$ \\
\hline \multicolumn{12}{|l|}{ AUG } \\
\hline $27 \ldots$ & -- & -- & -- & $<0.2$ & -- & -. & -- & -- & - & - & $<0.2$ \\
\hline
\end{tabular}

611220149503600 - NF CHESTER こ $\equiv$ - 15TH AVE AT ANCHORAGE AK

WATER-QUALITY DATA, WATER YEAF :-OOOBER 1985 TO SEPTEMBER 198

\begin{tabular}{|c|c|c|c|c|c|c|c|c|c|c|c|}
\hline & & & $\mathrm{N}-$ & & & & & & & & \\
\hline & & METHYL- & NITRO- & N-NITRO & N-NITFE & & PARA- & & & TE-T- & TRI - \\
\hline & METHYL- & ENE & SODI -N- & -SODI - & -SODI - & & CHLORO- & & & $C=:=0-$ & CHLORO- \\
\hline & $\begin{array}{l}\text { CHLO- } \\
\text { RIDE }\end{array}$ & $\begin{array}{l}\text { CHLO- } \\
\text { RIDE }\end{array}$ & $\begin{array}{l}\text { PROPYL- } \\
\text { AMINE }\end{array}$ & $\begin{array}{l}\text { PHENY - } \\
\text { LAMINE }\end{array}$ & $\begin{array}{l}\text { METHY - } \\
\text { LAMINIE }\end{array}$ & $\begin{array}{l}\text { UITRO- } \\
\text { 3ENZENE }\end{array}$ & $\begin{array}{c}\text { META } \\
\text { CRESOL }\end{array}$ & $\begin{array}{l}\text { PHENAN- } \\
\text { THRENE }\end{array}$ & $\because \therefore R E N E$ & $\begin{array}{c}\text { ETE-- } \\
\text { 밒 }\end{array}$ & $\begin{array}{l}\text { FLUORO- } \\
\text { METHANE }\end{array}$ \\
\hline & TOTAL & TOTAL & TOTAL & TOTAL & TOTA: & TOTAL & TOTAL & TOTAL & IOTAL & $T:==$ & TOTAL \\
\hline & $(\mathrm{UG} / \mathrm{L})$ & (UG/L) & $(U G / L)$ & $(U G ; L)$ & (UG 'L) & .UG /L) & (UG/L & $(U G / L)$ & $(-G, L)$ & $10=-$ & $(\mathrm{UG} / \mathrm{L})$ \\
\hline & $(34418)$ & $(34423)$ & $(34428)$ & $(34433)$ & $13443 E$ & 344471 & $(34452)$ & $(34461)$ & $\vdots 44691$ & 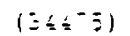 & $(34488)$ \\
\hline
\end{tabular}

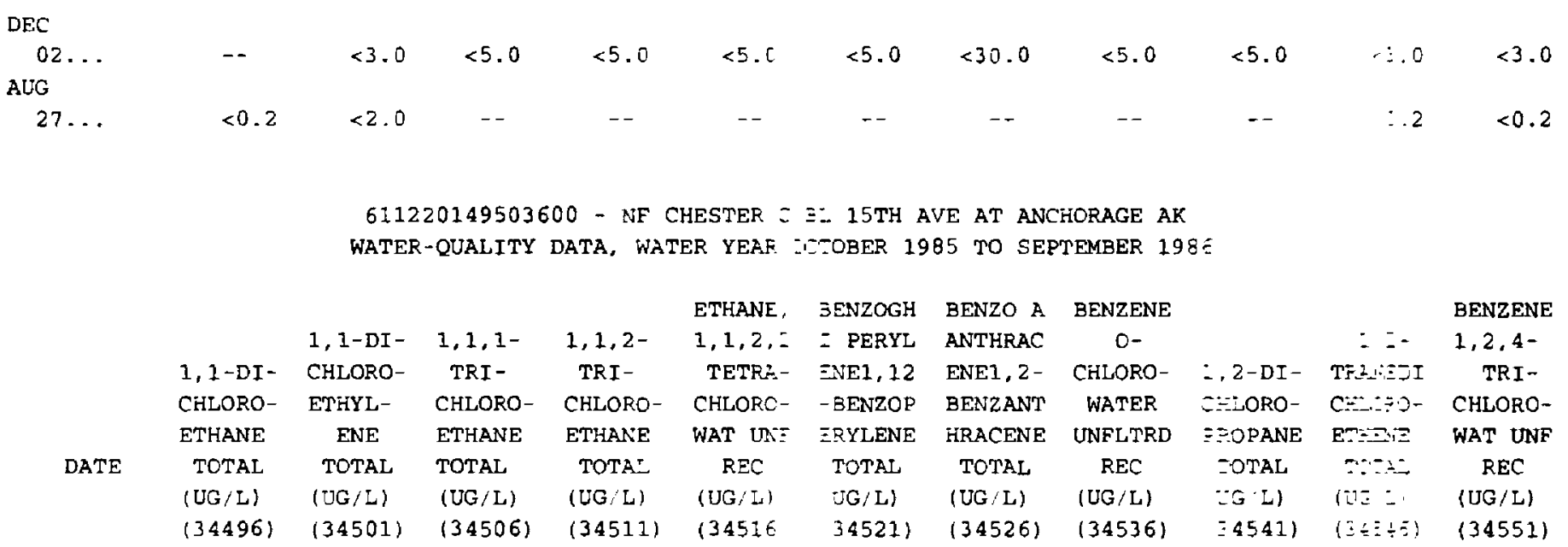

\begin{tabular}{|c|c|c|c|c|c|c|c|c|c|c|c|}
\hline \multicolumn{12}{|l|}{ DEC } \\
\hline $02 \ldots$ & $<3.0$ & $<3.0$ & $<3.0$ & $<3.0$ & $<3 .:$ & $<10.0$ & $<5.0$ & $<5.0$ & $<3.0$ & $\therefore 0$ & $<5.0$ \\
\hline \multicolumn{12}{|l|}{ AUG } \\
\hline $27 \ldots$ & 0.2 & $<0.2$ & $<0.2$ & $<0.2$ & $<0 .:$ & - & - - & $<0.20$ & $<0.2$ & $\therefore 2$ & -- \\
\hline
\end{tabular}




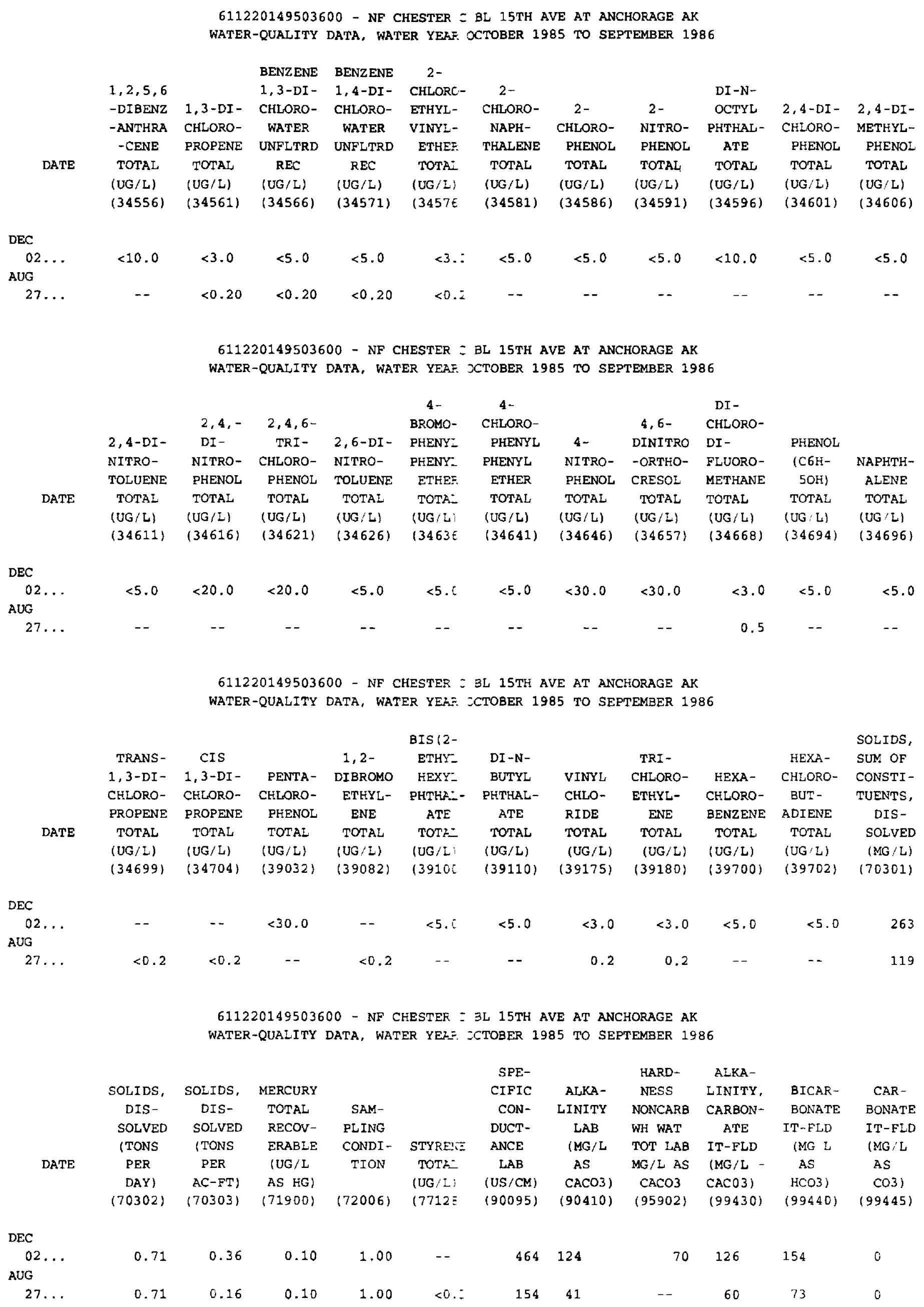


611254149491700 - NF CHESTER C AT AIRPORT HTS RD NR ANCHORAGE AK WATER-QUALITY DATA, WATER YEAR OCTOBER 1971 TO SEPTEMBER 1972

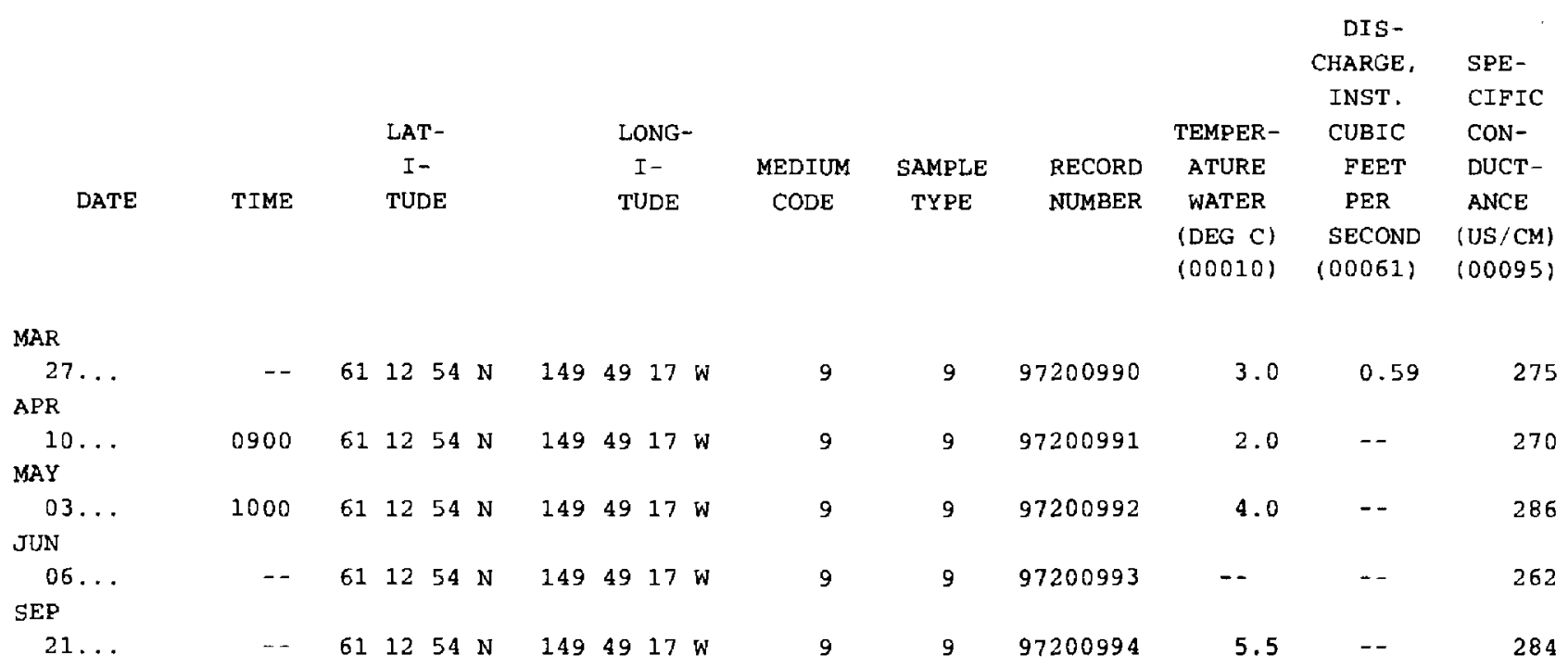

611254149491700 - NF CHESTER C AT AIRPORT HTS RD NR ANCHORAGE AK WATER-QUALITY DATA, WATER YEAR OCTOBER 1971 TO SEPTEMBER 1972

\begin{tabular}{|c|c|c|c|c|c|c|c|c|c|c|}
\hline & & $\begin{array}{c}\text { PH } \\
\text { WATER } \\
\text { WHOLE }\end{array}$ & $\begin{array}{r}\text { CARBON } \\
\text { DIOXIDE }\end{array}$ & $\begin{array}{l}\text { ALKA- } \\
\text { LINITY } \\
\text { WAT WH }\end{array}$ & $\begin{array}{r}\text { BICAR- } \\
\text { BONATE } \\
\text { WATER }\end{array}$ & $\begin{array}{c}\text { CAR- } \\
\text { BONATE } \\
\text { WATER }\end{array}$ & $\begin{array}{l}\text { NITRO- } \\
\text { GEN, } \\
\text { NITRITE }\end{array}$ & $\begin{array}{l}\text { NITRO- } \\
\text { GEN, } \\
\text { NITRATE }\end{array}$ & $\begin{array}{l}\text { PHOS- } \\
\text { PHATE, } \\
\text { ORTHO, }\end{array}$ & PHOS- \\
\hline$T E$ & $\begin{array}{c}\text { OXYGEN, } \\
\text { DIS- } \\
\text { SOLVED }\end{array}$ & $\begin{array}{l}\text { FIELD } \\
\text { (STAND- } \\
\text { ARD }\end{array}$ & $\begin{array}{l}\text { DIS- } \\
\text { SOLVED } \\
\text { (MG/L }\end{array}$ & $\begin{array}{l}\text { TOT FET } \\
\text { FIELD } \\
\text { MG / L AS }\end{array}$ & $\begin{array}{c}\text { WH FET } \\
\text { FIELD } \\
\text { MG/L AS }\end{array}$ & $\begin{array}{c}\text { WH FET } \\
\text { FIELD } \\
\text { MG /L AS }\end{array}$ & $\begin{array}{l}\text { DIS- } \\
\text { SOLVED } \\
\text { (MG/L }\end{array}$ & $\begin{array}{l}\text { DIS- } \\
\text { SOLVED } \\
\text { (MG/L }\end{array}$ & $\begin{array}{l}\text { DIS- } \\
\text { SOLVED } \\
\text { (MG:L }\end{array}$ & $\begin{array}{r}\text { PHORUS } \\
\text { TOTAL } \\
\text { (MG /L }\end{array}$ \\
\hline & $\begin{array}{r}(M G / L) \\
(00300)\end{array}$ & $\begin{array}{r}\text { UNITS }) \\
(00400)\end{array}$ & $\begin{array}{l}\text { AS CO2) } \\
(00405)\end{array}$ & $\begin{array}{c}\mathrm{CACO} 3 \\
(00410)\end{array}$ & $\begin{array}{l}\mathrm{HCO} 3 \\
(00440)\end{array}$ & $\begin{array}{c}\operatorname{co3} \\
(00445)\end{array}$ & $\begin{array}{c}\text { AS N) } \\
(00613)\end{array}$ & $\begin{array}{c}\text { AS N) } \\
(00618)\end{array}$ & $\begin{array}{l}\text { AS PO4) } \\
(00660)\end{array}$ & $\begin{array}{c}\text { AS P) } \\
(00665)\end{array}$ \\
\hline
\end{tabular}

\begin{tabular}{|c|c|c|c|c|c|c|c|c|c|c|}
\hline \multicolumn{11}{|l|}{ MAR } \\
\hline $27 \ldots$ & -- & 7.3 & 11 & 96 & 120 & 0 & 0.001 & 1.10 & 0.0 & 0.050 \\
\hline \multicolumn{11}{|l|}{ APR } \\
\hline $10 \ldots$ & 8.2 & -- & -- & 99 & 120 & 0 & 0.001 & 1.10 & 0.0 & 0.050 \\
\hline \multicolumn{11}{|l|}{ MAY } \\
\hline $03 \ldots$ & 10.2 & 7.0 & 7.8 & 40 & 49 & 0 & 0.003 & 0.080 & 0.06 & 0.060 \\
\hline \multicolumn{11}{|l|}{ JUN } \\
\hline $06 \ldots$ & 7.3 & 6.6 & 39 & 89 & 110 & 0 & 0.002 & 0.720 & 0.0 & 0.050 \\
\hline \multicolumn{11}{|l|}{ SEP } \\
\hline $21 \ldots$ & 6.2 & 6.6 & 42 & 86 & 100 & 0 & -. & 1.30 & 0.0 & 0.060 \\
\hline
\end{tabular}

611254149491700 - NF CHESTER C AT AIRPORT HTS RD NR ANCHORAGE AK WATER-QUALITY DATA, WATER YEAR OCTOBER 1971 TO SEPTEMBER 1972

\begin{tabular}{|c|c|c|c|c|c|c|c|c|c|}
\hline PHOS- & PHOS- & PHOS- & & HARD- & & & & & \\
\hline $\begin{array}{l}\text { PHORUS } \\
\text { ORTHO, }\end{array}$ & $\begin{array}{l}\text { PHORUS } \\
\text { HYDRO- }\end{array}$ & $\begin{array}{r}\text { PHORUS } \\
\text { HYDRO. }\end{array}$ & $\begin{array}{l}\text { HARD- } \\
\text { NESS }\end{array}$ & $\begin{array}{c}\text { NESS } \\
\text { NONCARB }\end{array}$ & CALCIUM & $\begin{array}{l}\text { MAGNE- } \\
\text { SIUM, }\end{array}$ & SODIUM, & $\begin{array}{c}\text { SODIUM } \\
\text { A.D- }\end{array}$ & \\
\hline $\begin{array}{l}\text { DIS- } \\
\text { SOLVED } \\
\text { (MG / L }\end{array}$ & $\begin{array}{l}\text { LYZABLE } \\
\text { DIS. } \\
\text { (MG/L }\end{array}$ & $\begin{array}{c}+ \text { ORTHO } \\
\text { DIS. } \\
\text { (MG / L }\end{array}$ & $\begin{array}{l}\text { TOTAL } \\
\text { (MG / L } \\
\text { AS }\end{array}$ & $\begin{array}{l}\text { WH WAT } \\
\text { TOT FLD } \\
\text { MG / L AS }\end{array}$ & $\begin{array}{l}\text { DIS- } \\
\text { SOLVED } \\
\text { (MG/L }\end{array}$ & $\begin{array}{l}\text { DIS- } \\
\text { SOLVED } \\
\text { (MG/L }\end{array}$ & $\begin{array}{l}\text { DIS- } \\
\text { SOLVED } \\
\text { (MG / L }\end{array}$ & $\begin{array}{l}\text { SORP- } \\
\text { TION } \\
\text { RATIO }\end{array}$ & SODIUM \\
\hline & & AS P) & $(\mathrm{CACO} 31$ & $\mathrm{CACO} 3$ & AS CA) & AS MG) & AS NA) & & ENT \\
\hline 100671 & $(00672)$ & $(00677)$ & $(00900)$ & $(00902)$ & $(00915)$ & $(00925)$ & $(00930)$ & $(00931)$ & $(00932)$ \\
\hline
\end{tabular}

\begin{tabular}{|c|c|c|c|c|c|c|c|c|c|c|}
\hline MAR & & & & & & & & & & \\
\hline $27 \ldots$ & 0.00 & -- & -- & 110 & 14 & 35 & 5.4 & -- & - - & -- \\
\hline APR & & & & & & & & & & \\
\hline $10 \ldots$ & 0.00 & -- & -- & 130 & 31 & 34 & 10 & -- & $\cdots$ & -- \\
\hline MAY & & & & & & & & & & \\
\hline $03 \ldots$ & 0.020 & -- & -- & -- & -- & -- & -- & $\cdots$ & $\cdots$ & -- \\
\hline JUN & & & & & & & & & & \\
\hline $06 \ldots$ & 0.00 & 0.02 & 0.02 & 140 & 51 & 36 & 11 & -- & -- & $\cdots$ \\
\hline SEP & & & & & & & & & & \\
\hline $21 \ldots$ & 0.00 & $\cdots$ & -- & 130 & 44 & 34 & 12 & 5.5 & 0.2 & \\
\hline
\end{tabular}




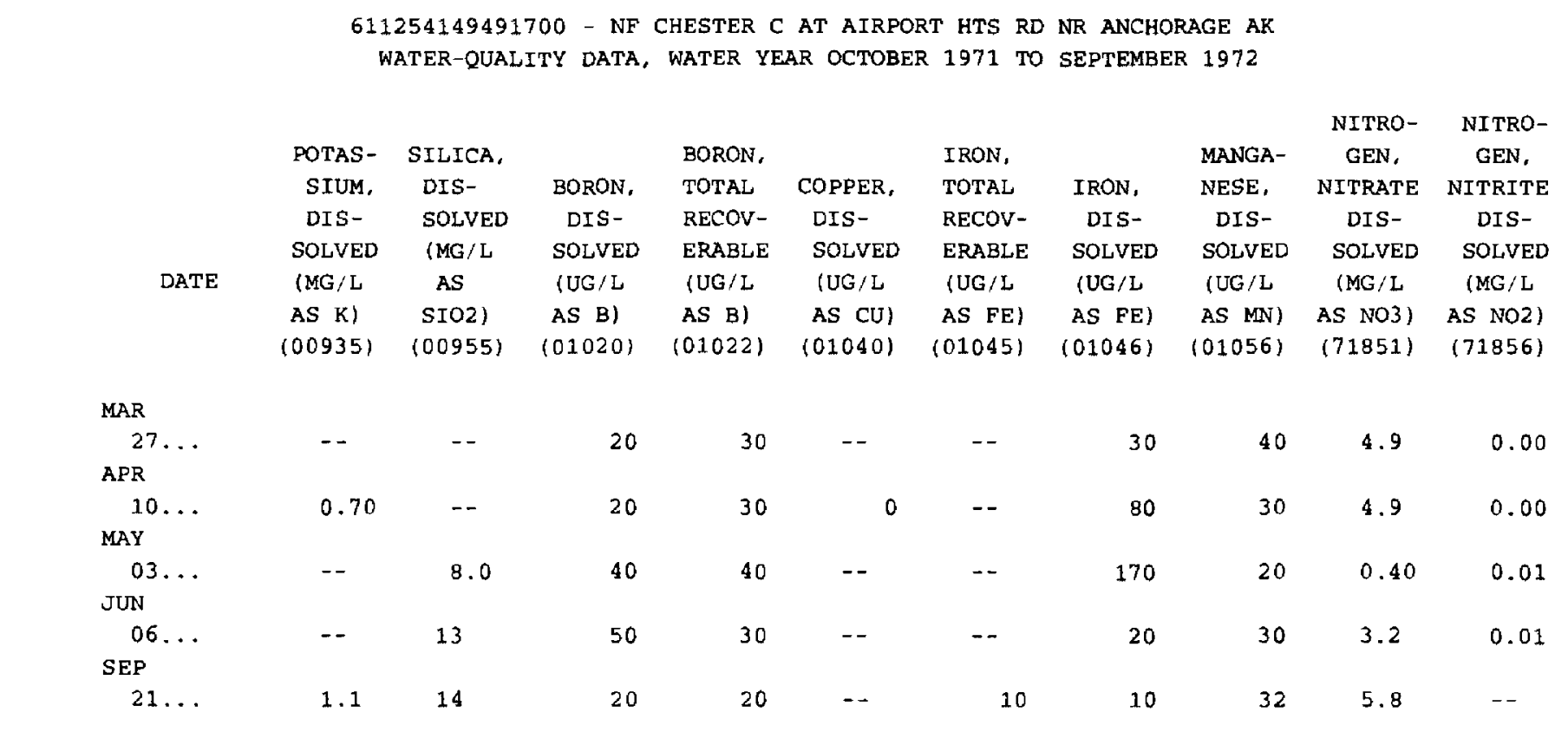

611254149491700 - NF CHESTER C AT AIRPORT HTS RD NR ANCHORAGE AK WATER-QUALITY DATA, WATER YEAR OCTOBER 1985 TO SEPTEMBER 1986

\begin{tabular}{|c|c|c|c|c|c|c|c|c|c|c|c|}
\hline & & \multirow{6}{*}{$\begin{array}{l}\text { LAT- } \\
\text { I- } \\
\text { TUDE }\end{array}$} & \multirow{6}{*}{$\begin{array}{l}\text { LONG- } \\
\text { I- } \\
\text { TUDE }\end{array}$} & \multirow{6}{*}{$\begin{array}{l}\text { MEDIUM } \\
\text { CODE }\end{array}$} & \multirow{6}{*}{$\begin{array}{l}\text { SAMPLE } \\
\text { TYPE }\end{array}$} & \multirow{6}{*}{$\begin{array}{l}\text { RECORD } \\
\text { NUMBER }\end{array}$} & \multirow{5}{*}{$\begin{array}{c}\text { TEMPER- } \\
\text { ATURE } \\
\text { WATER } \\
\text { (DEG C) }\end{array}$} & $\begin{array}{l}\text { AGENCY } \\
\text { COL- }\end{array}$ & $\begin{array}{c}\text { AGENCY } \\
\text { ANA- }\end{array}$ & $\begin{array}{l}\text { SPE- } \\
\text { CIFIC }\end{array}$ & \\
\hline \multirow{5}{*}{ DATE } & \multirow{5}{*}{ TIME } & & & & & & & LECTING & LYZING & CON- & $S:-1 E=E$ \\
\hline & & & & & & & & SAMPLE & SAMPLE & DUCT - & $T: \equiv=\Omega-$ \\
\hline & & & & & & & & (CODE & (CODE & ANCE & $\mathrm{rg}=\mathrm{T}$ \\
\hline & & & & & & & & NUMBER) & NUMBER) & (US/CM) & (C:ニミミ) \\
\hline & & & & & & & $(00010)$ & $(00027)$ & $(00028)$ & $(00095)$ & $(0:: 25)$ \\
\hline
\end{tabular}

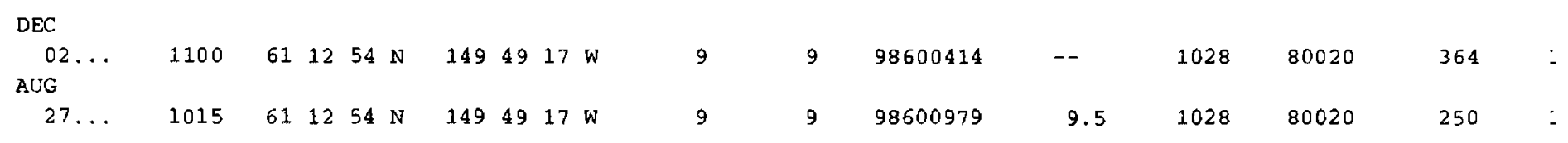

611254149491700 - NF CHESTER C AT AIRPORT HTS RD NR ANCHORAGE AK WATER-QUALITY DATA, WATER YEAR OCTOBER 1985 TO SEPTEMBER 1986

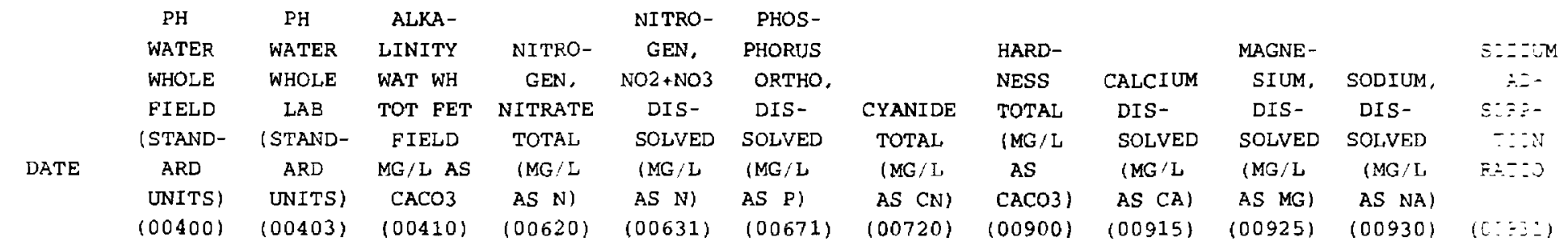

DEC

$\begin{array}{cccccccccccccc}02 \ldots & -- & 8.2 & 93 & 2.00 & 2.00 & <0.010 & <0.010 & 160 & 42 & 13 & 11 & \vdots .4 \\ \begin{aligned} \text { AUG } \\ 27 \ldots\end{aligned} & 6.7 & 7.3 & 65 & 1.30 & 1.30 & <0.010 & -- & 110 & 29 & 8.4 & 8.9 & \therefore .4\end{array}$

611254149491700 - NF CHESTER C AT AIRPORT HTS RD NR ANCHORAGE AK WATER-QUALITY DATA, WATER YERR OCTOBER 1985 TO SEPTEMBER 1986

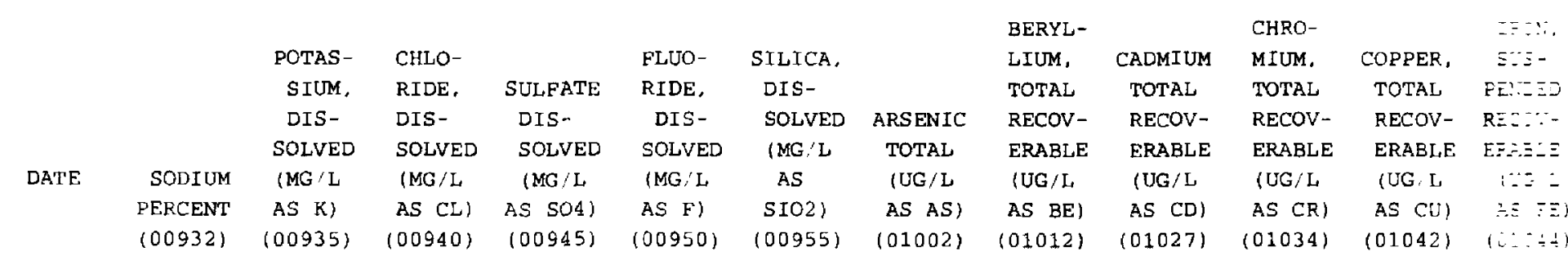

DEC

\begin{tabular}{|c|c|c|c|c|c|c|c|c|c|c|c|c|}
\hline $02 \ldots$ & 13 & 1.5 & 41 & 23 & $<0.10$ & 16 & $<1$ & $<10$ & $<1$ & 8 & 1 & $\therefore \div 0$ \\
\hline AUG & & & & & & & & & & & & \\
\hline $27 \ldots$ & 15 & 1.3 & 25 & 19 & 0.10 & 12 & 2 & -- & $<1$ & 14 & 10 & $\cdots$ \\
\hline
\end{tabular}


611254149491700 - NE CHESTER $C$ AT AIRPORT HTS RD NR ANCHORAGE AK WATER-QUALITY DATA, WATER YEAR OCTOBER 1985 TO SEPTEMBER 1986

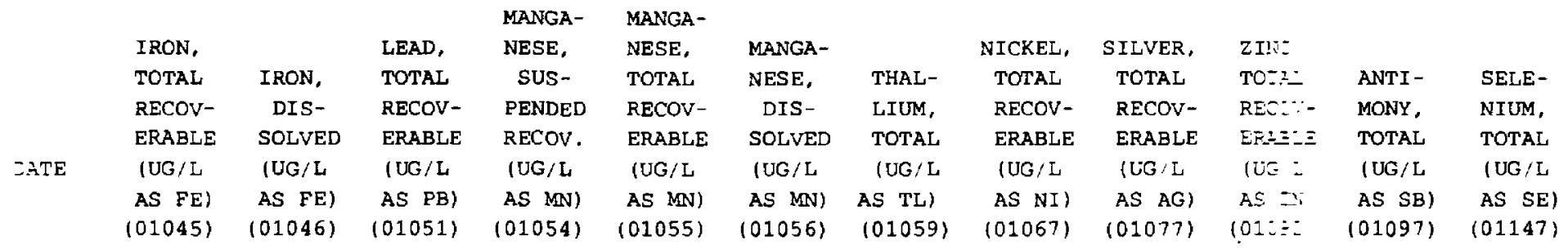

\begin{tabular}{|c|c|c|c|c|c|c|c|c|c|c|c|c|}
\hline ZEC & & & & & & & & & & & & \\
\hline $02 \ldots$ & 510 & 370 & $<1$ & 10 & 60 & 46 & $<1$ & 1 & $<1$ & $\therefore:$ & $<1$ & $<1$ \\
\hline \multicolumn{13}{|l|}{$\because G$} \\
\hline $27 \ldots$ & 3900 & 160 & $<5$ & - & 130 & 41 & -- & 6 & $\ldots$ & $\therefore \therefore:$ & $<1$ & - \\
\hline
\end{tabular}

611254149491700 - NE CHESTER C AT AIRPORT HTS RD NR ANCHORAGE AK WATER-QUALITY DATA, WATER YEAR OCTOBER 1985 TO SEPTEMBER 1986

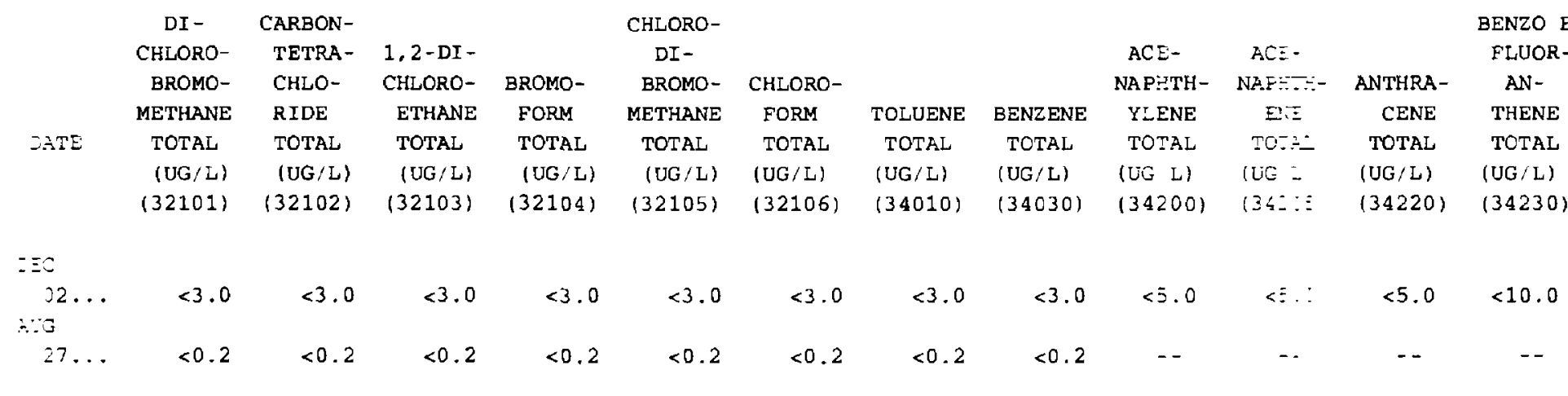

611254149491700 - NF CHESTER C AT AIRPORT HTS RD NR ANCHORAGE AK WATER-QUALITY DATA, WATER YEAR OCTOBER 1985 TO SEPTEMBER 1966

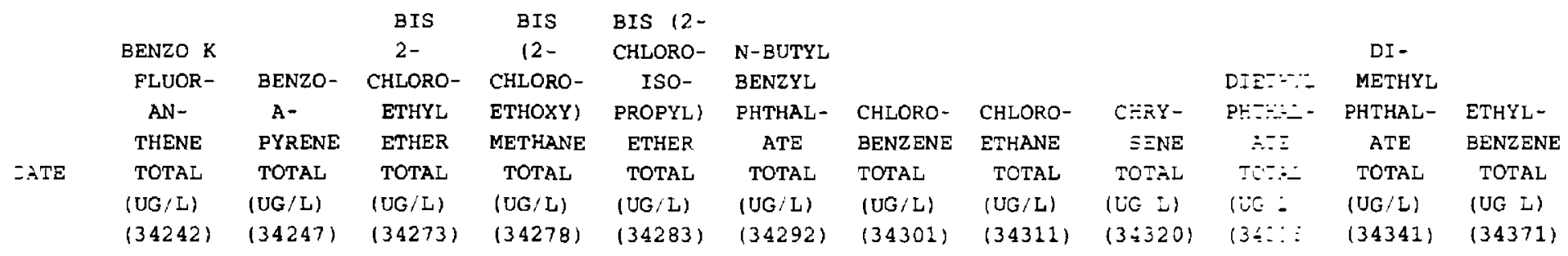

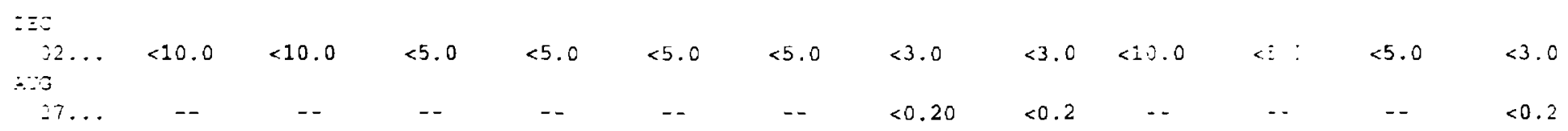

611254149491700 - NF CHESTER C AT AIRPORT HTS RD NR ANCHORAGE AK WATER-QUALITY DATA, WATER YEAR OCTOBER 1985 TO SEPTEMBER 1956

\begin{tabular}{|c|c|c|c|c|c|c|c|c|c|c|c|c|}
\hline & & & HEXA- & & & & & & & $\therefore-$ & & \\
\hline & & & CHLORO- & & INDENO & & & & ME $I \because Y L-$ & lis: & N-NITRO & N-NITRO \\
\hline & & & CYCLO- & HEXA- & $(1,2,3-$ & & & METHYL- & $\equiv a$ & soz:- & -SODI- & $\begin{array}{l}\text {-SODI- } \\
\text { METHY - }\end{array}$ \\
\hline & ANTHENE & ENE & ADIENE & $\begin{array}{r}\text { CHLORO- } \\
\text { ETHANE }\end{array}$ & $\begin{array}{c}\text { CD) } \\
\text { PYRENE }\end{array}$ & $\begin{array}{l}\text { ISO- } \\
\text { PHORONE }\end{array}$ & $\begin{array}{l}\text { METHYL- } \\
\text { BROMIDE }\end{array}$ & $\begin{array}{l}\text { CHLO- } \\
\text { RIDE }\end{array}$ & $\begin{array}{l}\text { C-OC- } \\
\text { RIDE }\end{array}$ & $\begin{array}{c}P F E=- \\
\therefore 1 \%=\overline{-}\end{array}$ & LAMINE & LAMINE \\
\hline TE & $\begin{array}{l}\text { TOTAL } \\
\text { (UG/L) }\end{array}$ & $\begin{array}{l}\text { TOTAL } \\
\text { (UG/L) }\end{array}$ & $\begin{array}{l}\text { TOTAL } \\
(\text { UG } / L)\end{array}$ & $\begin{array}{l}\text { TOTAL } \\
\text { (UG/L) }\end{array}$ & $\begin{array}{l}\text { TOTAL } \\
\{\text { UG / L \} }\end{array}$ & $\begin{array}{l}\text { TOTAL } \\
\text { (UG / L) }\end{array}$ & $\begin{array}{l}\text { TOTAL } \\
\text { (UG/L) }\end{array}$ & $\begin{array}{l}\text { TOTAL } \\
\text { (UG/L) }\end{array}$ & $\begin{array}{l}\text { TOE:I } \\
\text { (LC }=\text { ) }\end{array}$ & $\begin{array}{l}\text { TOE: } \\
\text { (LE: }\end{array}$ & $\begin{array}{l}\text { TOTAL } \\
\text { (UG/L) }\end{array}$ & $\begin{array}{l}\text { TOTAL } \\
\text { (UG 'L) }\end{array}$ \\
\hline & $(34376)$ & $(34381)$ & $(34386)$ & $(34396)$ & $\{34403\}$ & $(34408)$ & $(34413)$ & (34418) & $(34 \div 23)$ & 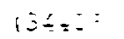 & $(34433)$ & $(34438)$ \\
\hline
\end{tabular}

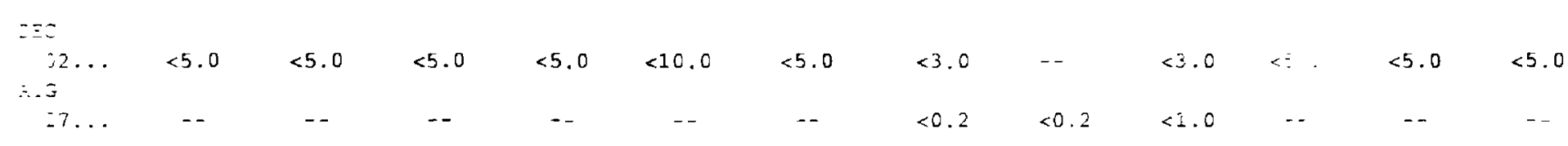


611254149491700 - NF CHESTER C AT AIRPORT HTS RD NR ANCHORAGE AK WATER-QUALITY DATA, WATER YEAR OCTOBER 1985 TO SEPTEMBER 1986

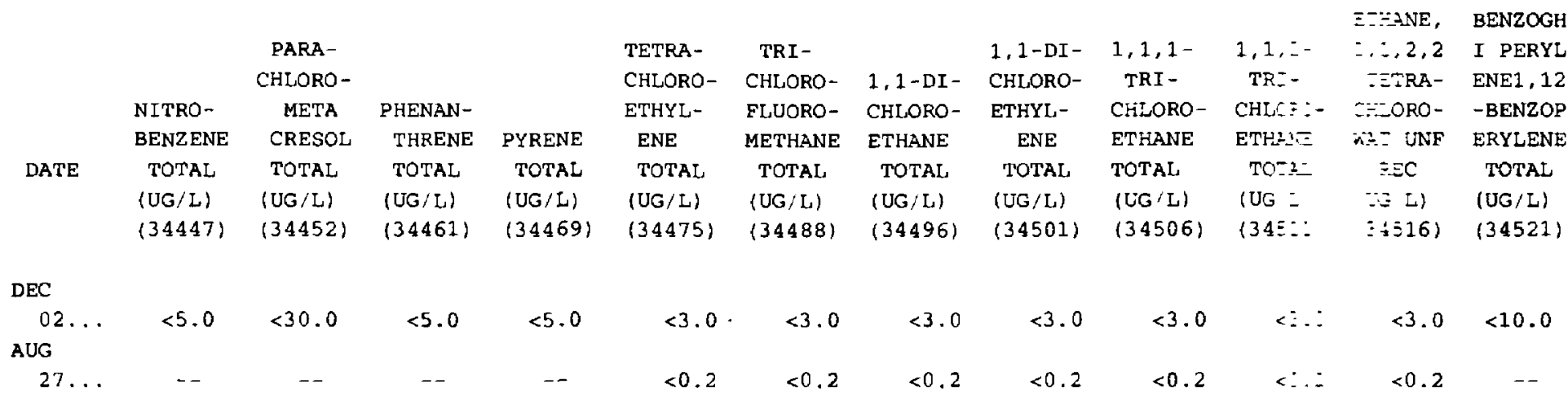

611254149491700 - NF CHESTER C AT AIRPORT HTS RD NR ANCHORAGE AK WATER-QUALITY DATA, WATER YEAR OCTOBER 1985 TO SEPTEMBER 1986

\begin{tabular}{|c|c|c|c|c|c|c|c|c|c|c|c|c|}
\hline & BENZO A & BENZENE & & & BENZENE & & & BENZENE & BENZENE & $2-$ & & \\
\hline & ANTHRAC & $0-$ & & $1,2-$ & $1,2,4-$ & $1,2,5,6$ & & $1.3-\mathrm{DI}-$ & $1.4-D I-$ & CHLE: :- & $=-$ & \\
\hline \multirow{2}{*}{$\mathrm{ATE}$} & (UG/L) & $(U G / L)$ & (UG/L) & (UG/L) & $(U G / L)$ & (UG/L) & (UG'L) & $(U G / L)$ & $(C E G)$ & (UG : & $\because=21$ & $(U G / L)$ \\
\hline & $(34526)$ & $\{34536\}$ & (34541) & $(34546)$ & (34551) & $(34556)$ & (34561) & $(34566)$ & $(34571)$ & $135=-\vdots$ & $\vdots \div 5811$ & $\{34586\}$ \\
\hline
\end{tabular}

\begin{tabular}{|c|c|c|c|c|c|c|c|c|c|c|c|c|}
\hline DEC & & & & & & & & & & & & \\
\hline $27 \ldots$ & -- & $<0.20$ & $<0.2$ & $<0.2$ & - - & -- & $<0.20$ & $<0.20$ & $<0.20$ & $<:$ & $\ldots$ & $=-$ \\
\hline
\end{tabular}

611254149491700 - NF CHESTER C AT AIRPORT HTS RD NR ANCHORAGE AK WATER-QUALITY DATA, WATER YEAR OCTOBER 1985 TO SEPTEMBER 1936

\begin{tabular}{|c|c|c|c|c|c|c|c|c|c|c|c|c|}
\hline & & & & & & & & & $4-$ & 4- & & \\
\hline & $\begin{array}{l}\text { NITRO- } \\
\text { PHENOL }\end{array}$ & $\begin{array}{c}\text { PHTHAL- } \\
\text { ATE }\end{array}$ & $\begin{array}{l}\text { CHLORO- } \\
\text { PHENOL }\end{array}$ & $\begin{array}{l}\text { METHYL- } \\
\text { PHENOL, }\end{array}$ & $\begin{array}{l}\text { NITRO- } \\
\text { TOLUENE }\end{array}$ & $\begin{array}{l}\text { NITRO- } \\
\text { PHENOL }\end{array}$ & $\begin{array}{l}\text { CHLORO- } \\
\text { PHENOL }\end{array}$ & $\begin{array}{l}\text { NITRO- } \\
\text { TOLUENE }\end{array}$ & $\begin{array}{r}\text { P:ENYL } \\
\text { ETHER }\end{array}$ & $\begin{array}{r}\text { PHE!:- } \\
E_{2}:=\end{array}$ & $\begin{array}{l}\because \because \text { ZRO- } \\
\because \because \text { INOL }\end{array}$ & $\begin{array}{l}\text {-ORTHO- } \\
\text { CRESOL }\end{array}$ \\
\hline & (34591) & $(34596)$ & $(34601)$ & $(34606)$ & $(34611)$ & $(34616)$ & $(34621)$ & $(34626)$ & $(34636)$ & $136 \div:$ & $\div \div 461$ & $(34657)$ \\
\hline
\end{tabular}

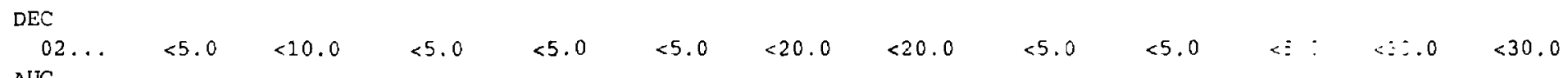

27.

611254149491700 - NF CHESTER C AT AIRPORT HTS RD NR ANCHORAGE AK WATER-QUALITY DATA, WATER YEAR OCTOBER 1985 TO SEPTEMBER 1986

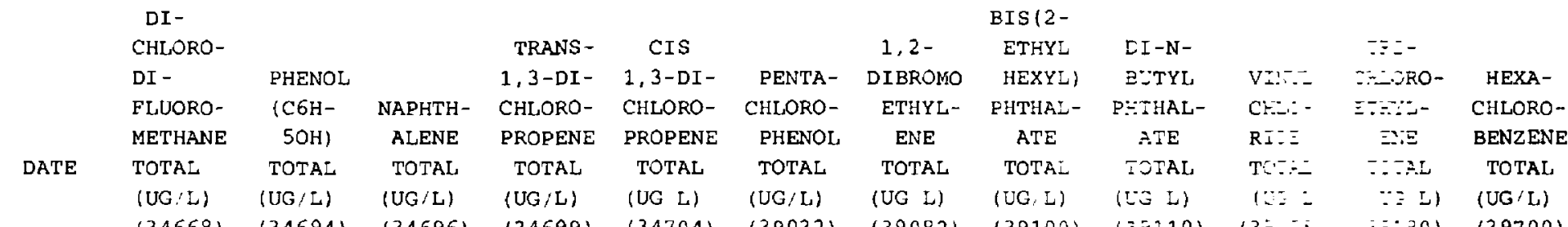

$\mathrm{DEC}$

\begin{tabular}{|c|c|c|c|c|c|c|c|c|c|c|c|c|}
\hline $02 \ldots$ & $<3.0$ & $<5.0$ & $<5.0$ & - & -- & $<30.0$ & -- & $<5.0$ & $<5.0$ & $\therefore$ & $<3.0$ & $<5.0$ \\
\hline & & & & & & & & & & & & \\
\hline $27 \ldots$ & 0.4 & -- & - & $<0.2$ & $<0.2$ & - - & $<0.2$ & -- & -- & c & $<3.2$ & -- \\
\hline
\end{tabular}


611254149491700 - NF CHESTER C AT AIRPORT HTS RD NR ANCHORAGE AK WATER-QUALITY DATA, WATER YEAR OCTOBER 1985 TO SEPTEMBER 1986

\begin{tabular}{|c|c|c|c|c|c|c|c|c|c|c|c|c|}
\hline & HEXA- & $\begin{array}{l}\text { SOLIDS, } \\
\text { SUM OF }\end{array}$ & SOLIDS, & MERCURY & & & $\begin{array}{r}\text { SPE- } \\
\text { CIFIC }\end{array}$ & ALKA- & $\begin{array}{l}\text { HARD- } \\
\text { NESS }\end{array}$ & $\begin{array}{l}\text { ALKA- } \\
\text { LINITY, }\end{array}$ & BICAR - & CAR- \\
\hline & $\begin{array}{l}\text { CHLORO- } \\
\text { BUT - }\end{array}$ & $\begin{array}{l}\text { CONSTI- } \\
\text { TUENTS, }\end{array}$ & $\begin{array}{c}\text { DIS- } \\
\text { SOLVED }\end{array}$ & $\begin{array}{l}\text { TOTAL } \\
\text { RECOV- }\end{array}$ & $\begin{array}{l}\text { SAM- } \\
\text { PL ING }\end{array}$ & & $\begin{array}{l}\text { CON- } \\
\text { DUCT- }\end{array}$ & $\begin{array}{c}\text { LINITY } \\
\text { LAB }\end{array}$ & $\begin{array}{l}\text { NONCARB } \\
\text { WH WAT }\end{array}$ & $\begin{array}{c}\text { CARBON- } \\
\text { ATE }\end{array}$ & $\begin{array}{l}\text { BONATE } \\
\text { IT-FID }\end{array}$ & BONATE \\
\hline & ADIENE & DIS- & ITONS & ERABLE & CONDI - & STYRENE & ANCE & (MG / L & TOT LAB & IT-FLD & (MG / L & (MG / L \\
\hline \multirow[t]{3}{*}{$\mathrm{AT}$} & TOTAL & SOLVED & PER & (UG / L & TION & TOTAL & LAB & AS & $M G / L$ AS & (MG/L - & AS & AS \\
\hline & (UG/L) & $(M G / L)$ & $A C-F T)$ & AS HG) & & $(\mathrm{UG} / \mathrm{L})$ & (US/CM) & (ACO3) & $\mathrm{CACO} 3$ & (ACO3) & $\mathrm{HCO} 31$ & $\cos 3)$ \\
\hline & (39702) & $(70301)$ & $(70303)$ & $(71900)$ & $(72006)$ & $(77128)$ & $(90095)$ & $(90410)$ & $(95902)$ & $(99430)$ & $(99440)$ & (99445) \\
\hline
\end{tabular}

\begin{tabular}{|c|c|c|c|c|c|c|c|c|c|c|c|c|}
\hline$D E C$ & & & & & & & & & & & & \\
\hline $27 \ldots$ & -- & 149 & 0.20 & $<0.10$ & 1.00 & $<0.2$ & 263 & 65 & -- & 66 & 80 & 0 \\
\hline
\end{tabular}




\section{APPENDIX 2}

Well inventory and water-quality data for wells in the Merrill Field airport area 


\section{EXPLANATION OF LOCAL NUMBER}

The local well-numbering system is based on the rectangular subdivision of public lands. The first two letters indicate the well's position in reference to a base and meridian (first letter) and the quadrant formed by the intersection of the base line and the principal meridian (second letter), lettered counter-clockwise from the northeast corner:

\begin{tabular}{|c|c|}
\hline$B$ & $A$ \\
\hline$C$ & $D$ \\
\hline
\end{tabular}

The first three digits indicate the township in which the well is located, the next three digits, the range, and the last two digits, the section. For example, a well in south Anchorage numbered SB01200329DBAD1 016 is located in township 12 north, range 3 west, section 29. Letters following the section number indicate further subdivision: the quarter section, the quarter-quarter section, and so forth to the fourth section subdivision. Like the quadrants formed by the base and meridian, each succeeding subdivision is lettered counter-clockwise from the northeast corner. The number after the letters refers to the sequential listing of wells in the smallest subdivision. Thus, well SB01200329DBAD1 was the first well located in the southeast quarter (D) of the northeast quarter (A) of the northwest quarter (B) of the southeast quarter (D) of section 29. The number following the fourth section subdivision is a sequence number referring to the number of wells in that fourth section subdivision.

T. $12 \mathrm{~N}$.

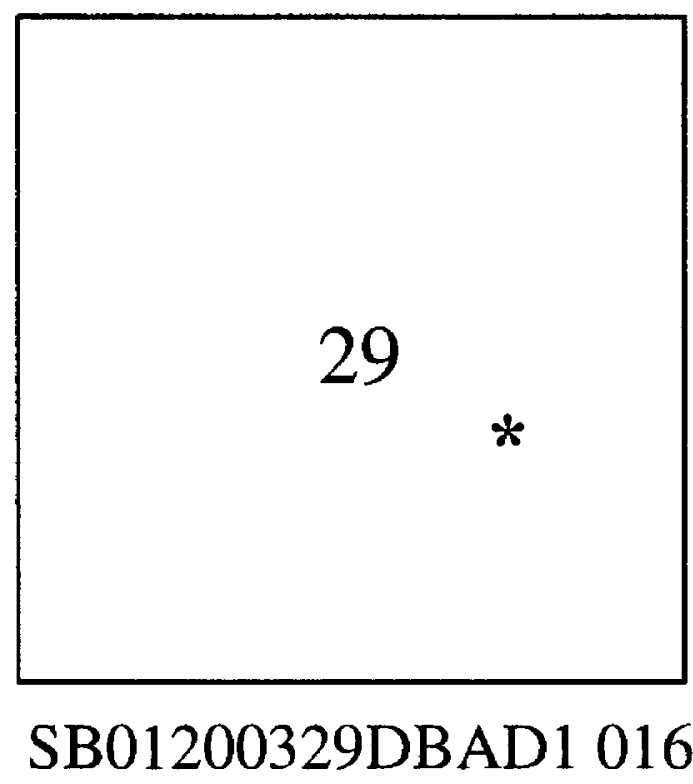




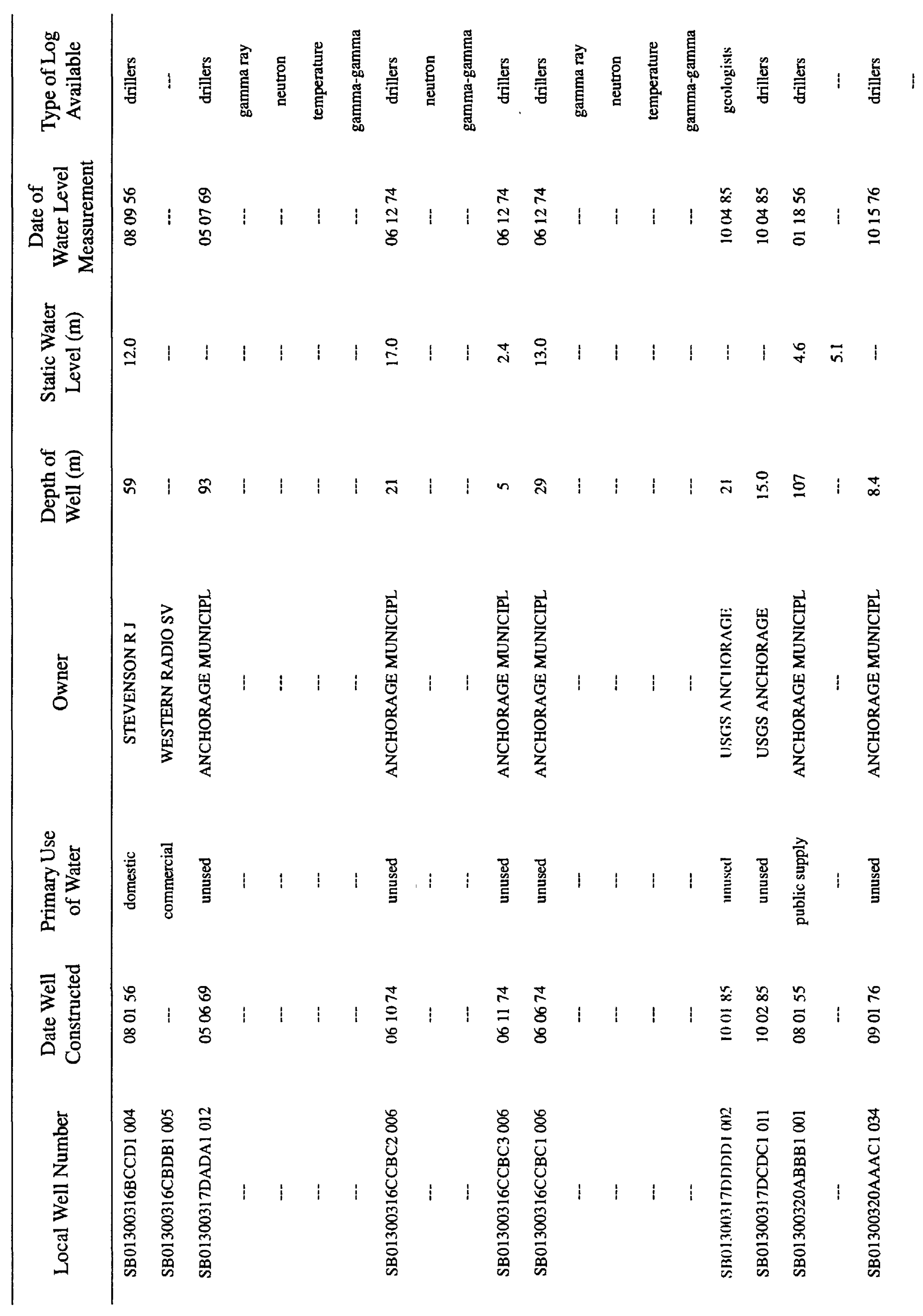




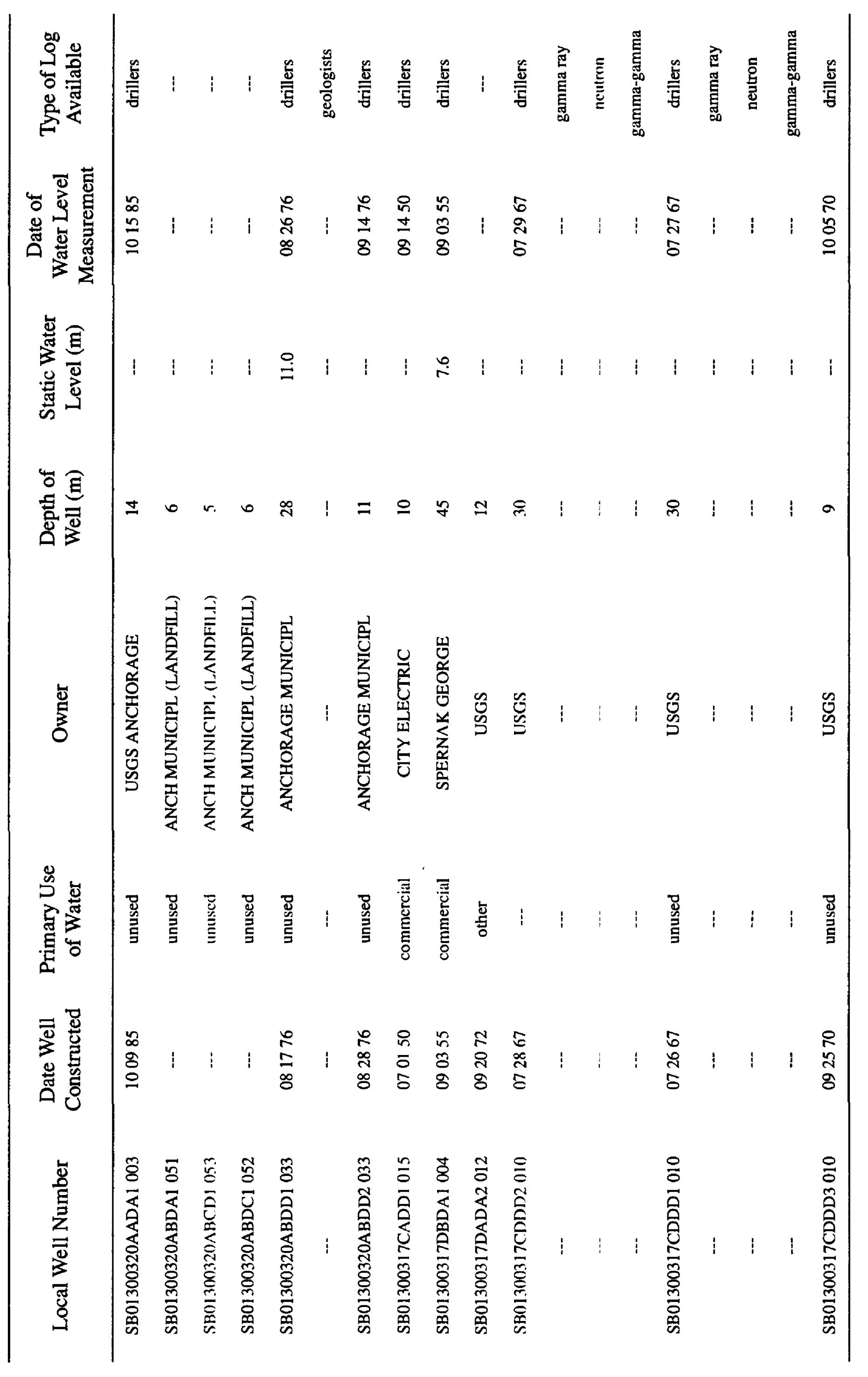




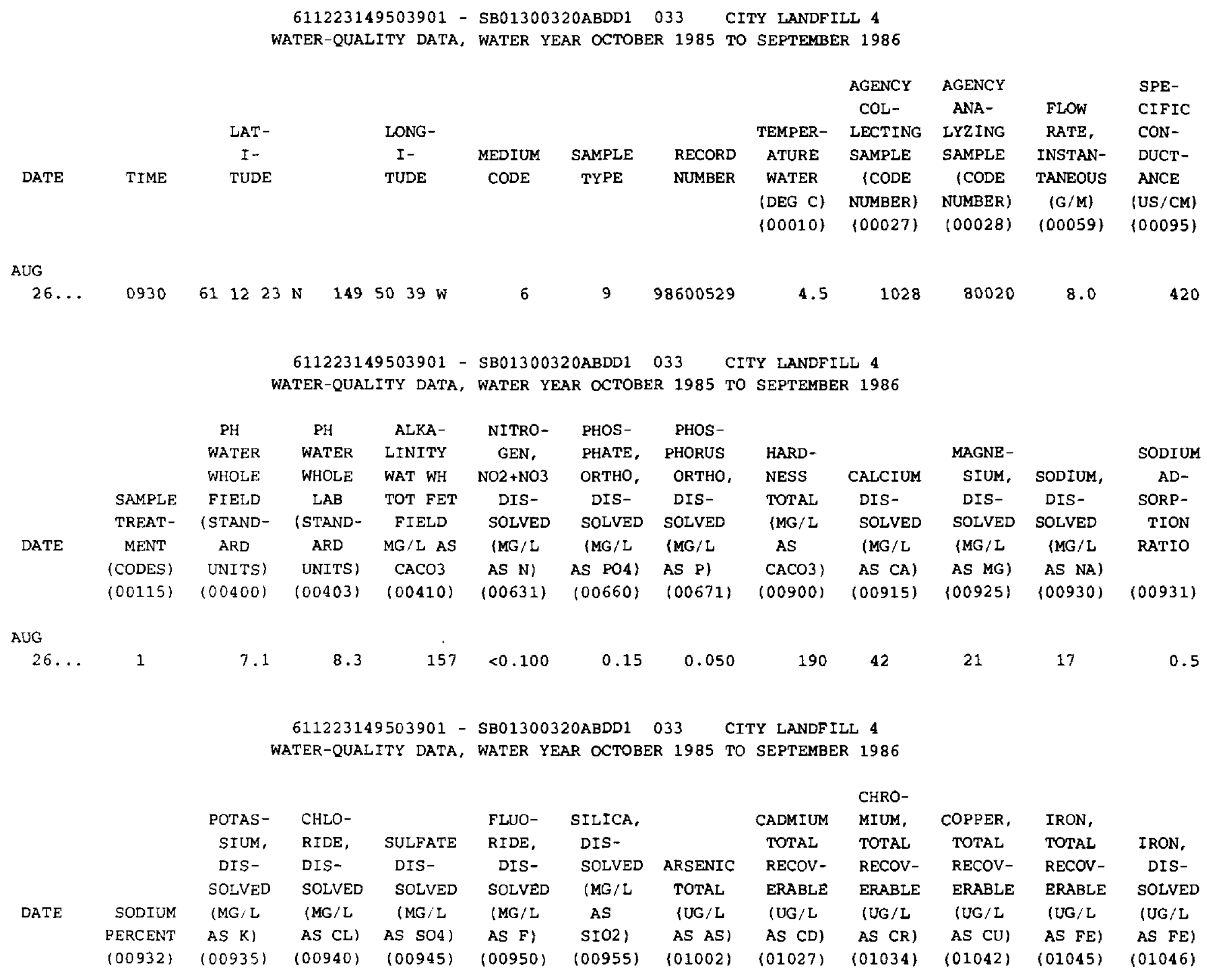

AUC

$\begin{array}{llllllllllll}26 \ldots & 16 & 2.4 & 19 & 51 & 0.10 & 13 & 23 & 1 & 9 & 3 & 370\end{array}$

611223149503901 - SB01300320ABDD1 033 CITY LANDFILL 4

WATER-QUALITY DATA, WATER YEAR OCTOBER 1985 TO SEPTEMBER 1986

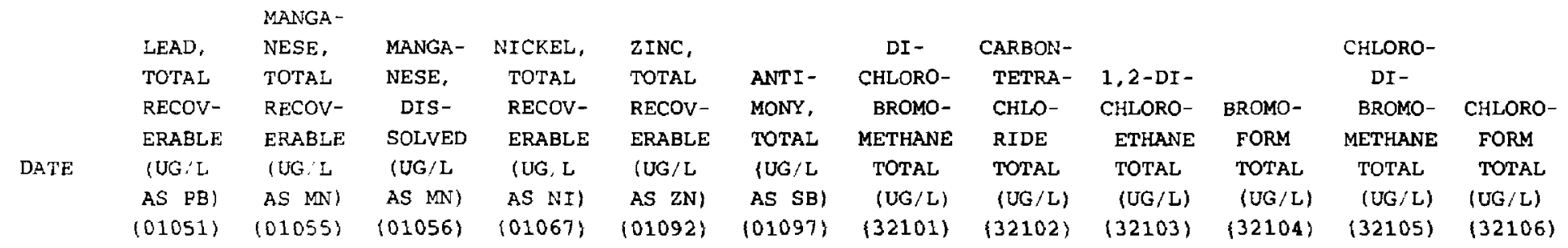

AUG

$\begin{array}{lllllllllllll}26 & 5 & 150 & 130 & 2 & 10 & 1 & <0.2 & 0.2 & <0.2 & <0.2 & <0.2 & 0.2\end{array}$

611223149503901 - SB01300320ABDD1 033 CITY LANDFILL 4

WATER-QUALITY DATA, WATER YEAR OCTOBER 1985 TO SEPTEMBER 1986

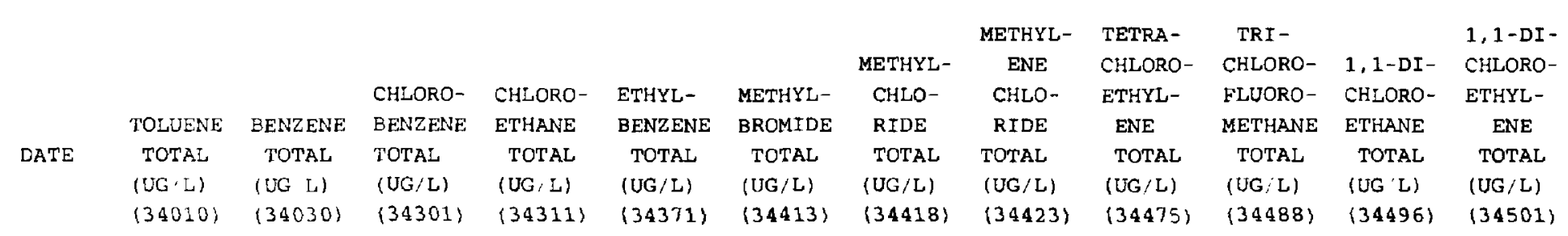

AUG

$\begin{array}{lllllllllllll}26 \ldots & 0.3 & <0.2 & <0.20 & <0.2 & <0.2 & <0.2 & <0.2 & 66 & <0.2 & 0.3 & <0.2 & <0.2\end{array}$ 
611223149503901 - SB01300320ABDD1 033 CITY LANDFILL 4

WATER-QUALITY DATA, WATER YEAR OCTOBER 1985 TO SEPTEMBER 1986

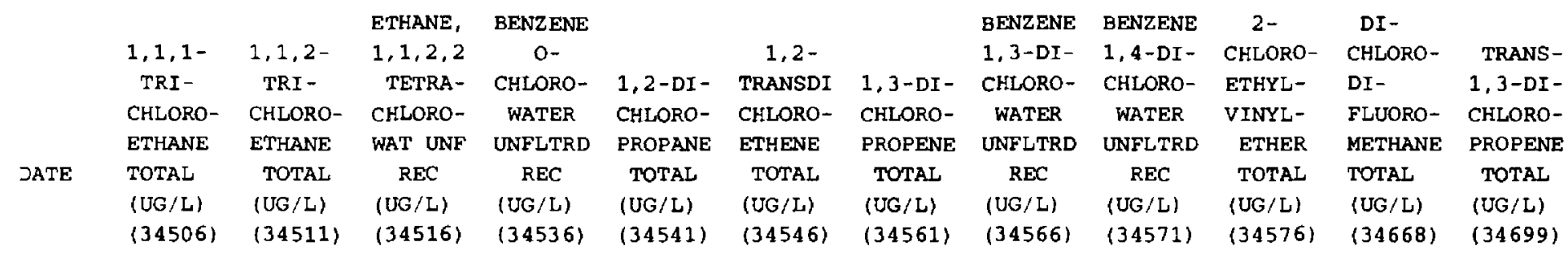

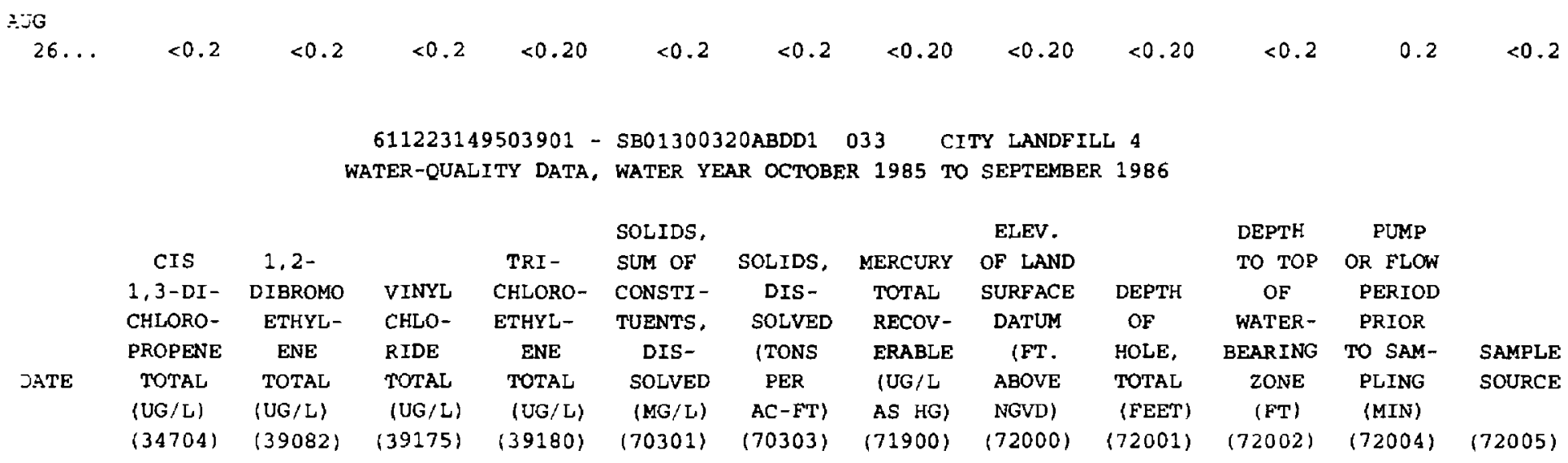

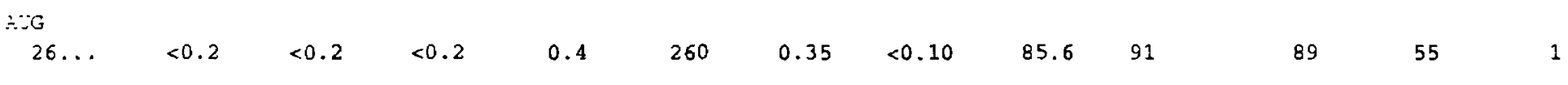

611223149503901 - SB01300320ABDD1 033 CITY LANDFILL 4

WATER-QUALITY DATA, WATER YEAR OCTOBER 1985 TO SEPTEMBER 1986

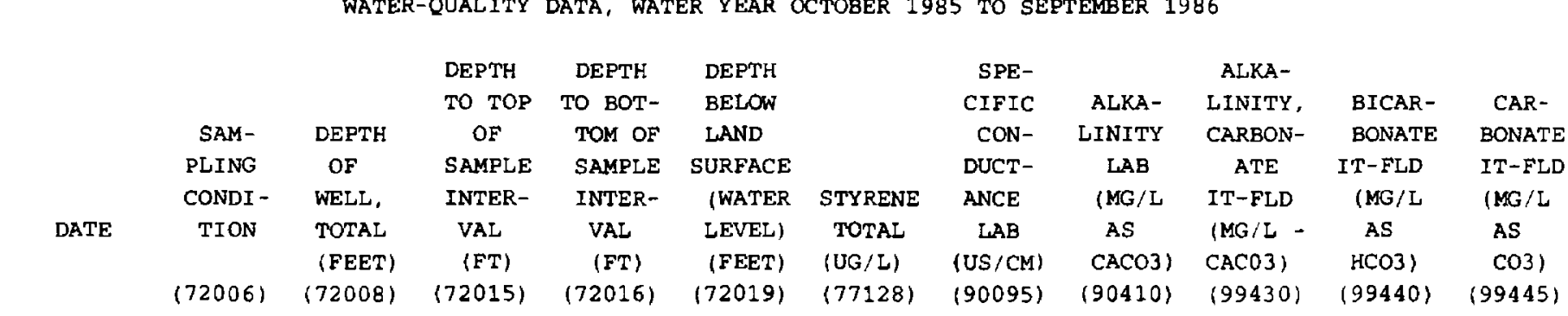

\begin{tabular}{|c|c|c|c|c|c|c|c|c|c|c|}
\hline$\therefore U G$ & & & & & & & & & & \\
\hline $26 \ldots$ & 1.00 & 91.00 & 91 & 91 & 6.02 & $<0.2$ & 449 & 157 & 157 & 191 \\
\hline
\end{tabular}

611223149503902 - SB01300320ABDD2 033 CITY LANDFILL 5 WATER-QUALITY DATA, WATER YEAR OCTOBER 1985 TO SEPTEMBER 1986

\begin{tabular}{|c|c|c|c|c|c|c|c|c|c|c|c|}
\hline & & & & & & & & AGENCY & AGENCY & FLOW & $\begin{array}{l}\text { SPE- } \\
\text { CIFIC }\end{array}$ \\
\hline
\end{tabular}

$\begin{array}{rllllllllllllllll}26 \ldots & 1035 & 61 & 12 & 23 \mathrm{~N} & 149 & 50 & 39 \mathrm{~W} & 6 & 9 & 98600535 & 5.0 & 1028 & 80020 & 2.0 & 850\end{array}$

611223149503902 - SB01300320ABDD2 033 CITY LANDFILL 5

WATER-QUALITY DATA, WATER YEAR OCTOBER 1985 TO SEPTEMBER 1986

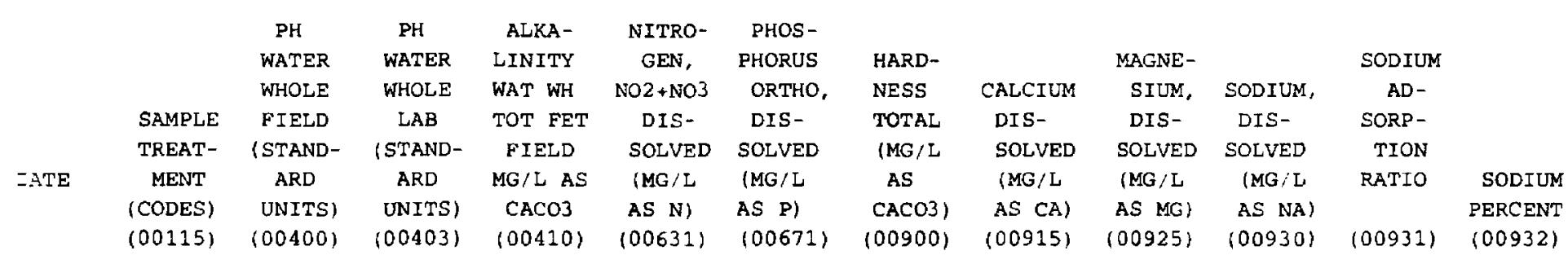

$\begin{array}{llllllllllll}\therefore 0 & & & & & & & & & & & \\ 26 & 1 & 6.8 & 7.1 & 217 & <0.100 & <0.010 & 290 & 82 & 20 & 59 & 2\end{array}$ 


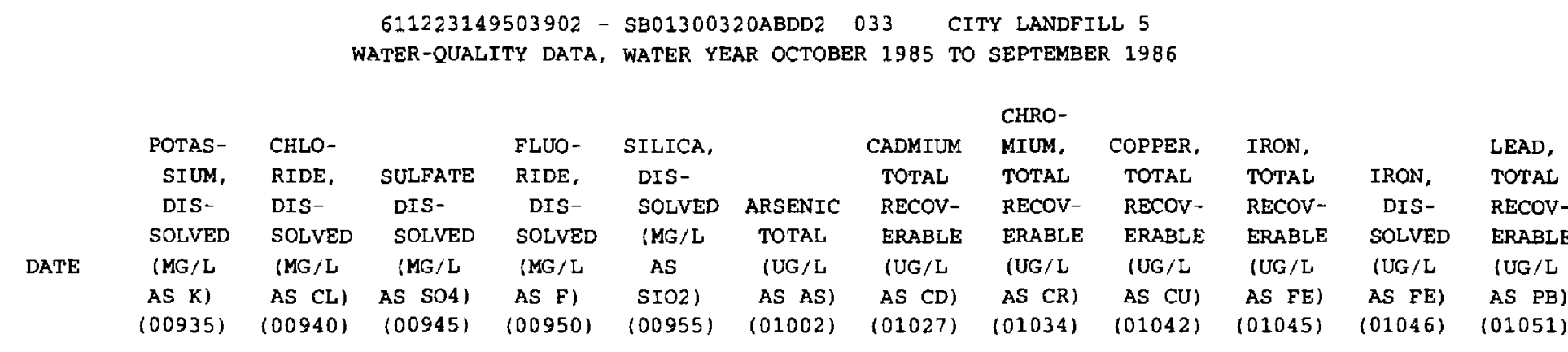

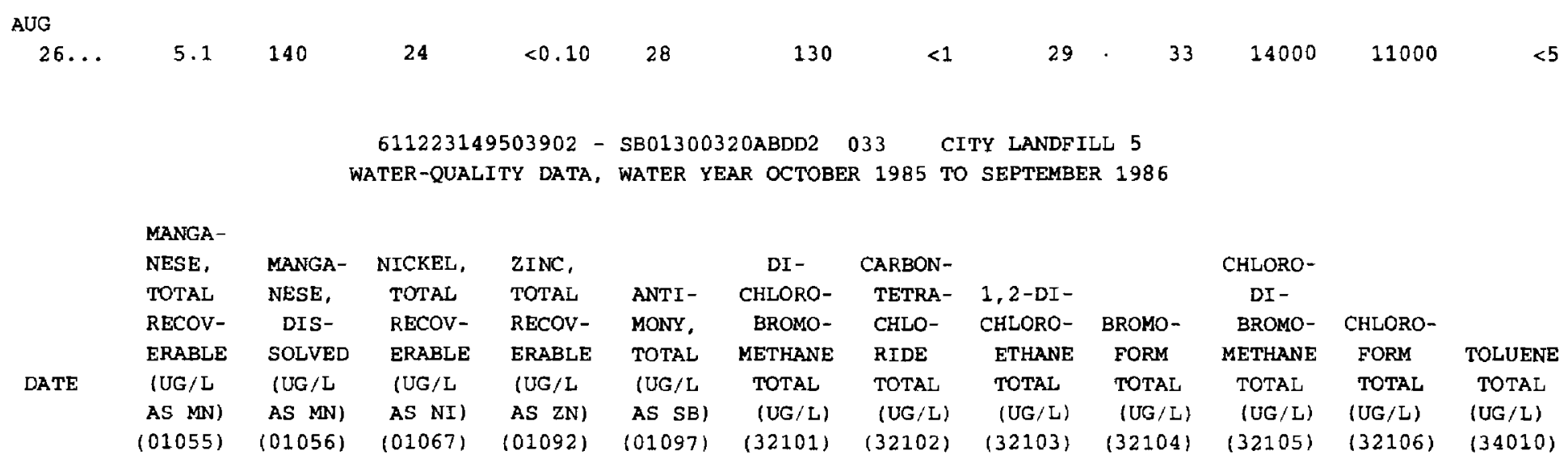

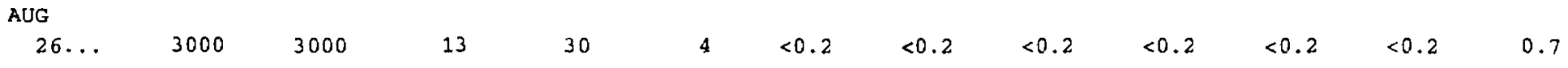

611223149503902 - SB01300320ABDD2 033 CITY LANDFILL 5

WATER-QUALITY DATA, WATER YEAR OCTOBER 1985 TO SEPTEMBER 1986

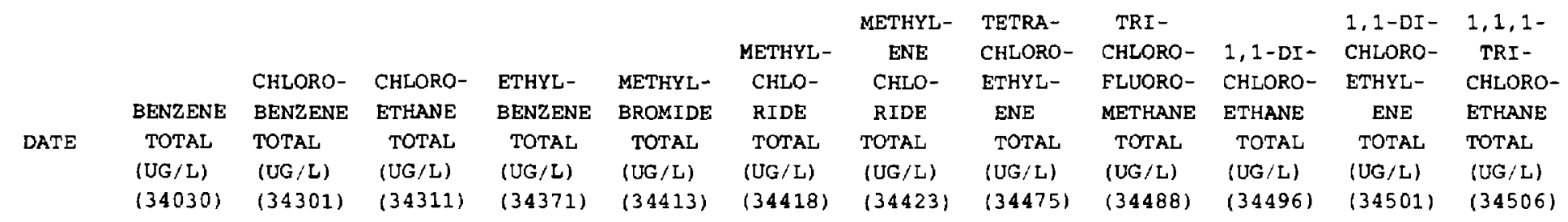

AUG

$\begin{array}{llllllllllllll}26 . . & <0.2<0.20 & <0.2 & <0.2 & <0.2 & <0.2 & <2.0 & <0.2 & <0.2 & 0.4 & <0.2< & <0.2\end{array}$

611223149503902 - SB01300320ABDD2 033 CITY LANDFILL 5

WATER-QUALITY DATA, WATER YEAR OCTOBER 1985 TO SEPTEMBER 1986

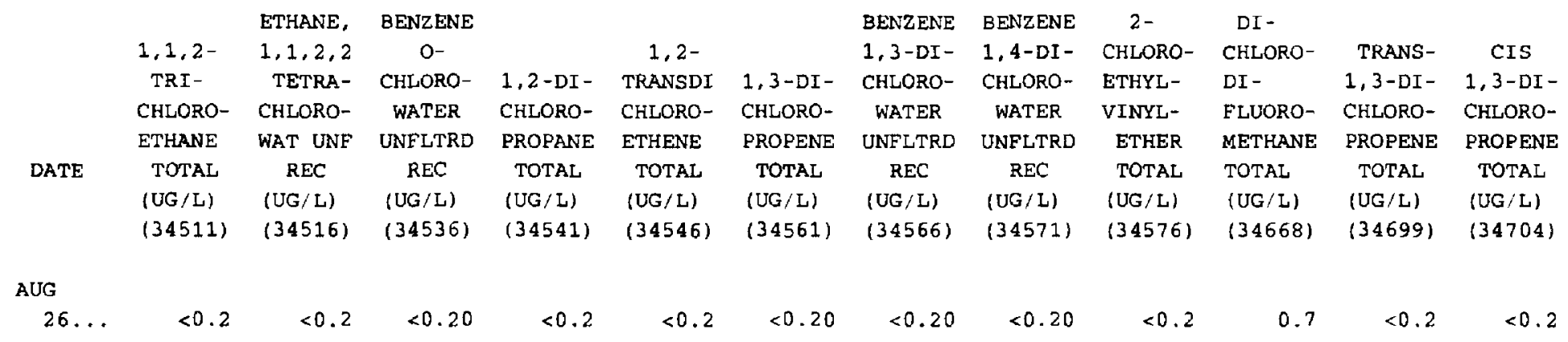

611223149503902 - SB01300320ABDD2 033 CITY LANDFILL 5 WATER-QUALITY DATA, WATER YEAR OCTOBER 1985 TO SEPTEMBER 1986

\begin{tabular}{|c|c|c|c|c|c|c|c|c|c|c|c|}
\hline \multirow{8}{*}{ ATE } & \multirow{5}{*}{$\begin{array}{c}1,2- \\
\text { DIBROMO } \\
\text { ETHYL- } \\
\text { ENE }\end{array}$} & \multirow{5}{*}{$\begin{array}{l}\text { VINYL } \\
\text { CHLO- } \\
\text { RIDE }\end{array}$} & \multirow{5}{*}{\multicolumn{2}{|c|}{$\begin{array}{c}\text { SOLIDS, } \\
\text { SUM OF } \\
\text { CONSTI- } \\
\text { TUENTS, } \\
\text { DIS- }\end{array}$}} & \multirow{5}{*}{$\begin{array}{l}\text { SOLIDS, } \\
\text { DIS- } \\
\text { SOLVED } \\
\text { (TONS }\end{array}$} & \multicolumn{3}{|c|}{ ELEV. } & \multicolumn{3}{|c|}{ PUMP } \\
\hline & & & & & & MERCURY & OF LAND & & TO BOT- & OR FLOW & \\
\hline & & & & & & TOTAL & SURFACE & DEPTH & TOM OF & PERIOD & \\
\hline & & & & & & RECOV- & DATUM & OF & WATER- & PRIOR & \\
\hline & & & & & & ERABLE & (FT. & HOLE, & BEARING & TO SAM- & SAMPLE \\
\hline & TOTAL & TOTAL & TOTAL & SOLVED & PER & (UG / L & ABOVE & TOTAL & ZONE & PLING & SOURCE \\
\hline & (UG/L) & $(U G / L)$ & (UG /L) & $(\mathrm{MG} / \mathrm{L})$ & $A C-F T$ & AS HG) & NGVD) & (FEET) & (FT) & (MIN) & \\
\hline & $(39082)$ & $(39175)$ & $(39180)$ & $(70301)$ & $(70303)$ & $(71900)$ & $(72000)$ & $(72001)$ & $(72003)$ & $(72004)$ & $(72005)$ \\
\hline
\end{tabular}

AUG

$\begin{array}{llllllllllll}26 \ldots & <0.2 & 0.9 & <0.2 & 504 & 0.69 & <0.10 & 86.0 & 45 & 35 & 60 & 1\end{array}$ 
611223149503902 - SB01300320ABDD2 033 CITY LANDFILL 5 WATER-QUALITY DATA, WATER YEAR OCTOBER 1985 TO SEPTEMBER 1986

\begin{tabular}{|c|c|c|c|c|c|c|c|c|c|c|c|}
\hline \multirow{6}{*}{ DATE } & & & DEPTH & DEPTH & DEPTH & & SPE- & & ALKA- & & \\
\hline & SAM- & DEPTH & $\begin{array}{c}\text { TO TOP } \\
\text { OF }\end{array}$ & $\begin{array}{l}\text { TO BOT- } \\
\text { TOM OF }\end{array}$ & $\begin{array}{l}\text { BELOW } \\
\text { LAND }\end{array}$ & & $\begin{array}{c}\text { CIFIC } \\
\text { CON- }\end{array}$ & $\begin{array}{l}\text { ALKA- } \\
\text { LINITY }\end{array}$ & $\begin{array}{l}\text { LINITY, } \\
\text { CARBON- }\end{array}$ & $\begin{array}{l}\text { BICAR- } \\
\text { BONATE }\end{array}$ & $\begin{array}{l}\text { CAR- } \\
\text { BONATE }\end{array}$ \\
\hline & PLING & $O F$ & SAMPLE & SAMPLE & SURFACE & & DUCT- & LAB & ATE & IT-FLD & IT-FLD \\
\hline & CONDI - & WELL, & INTER- & INTER- & (WATER & STYRENE & ANCE & (MG / L & IT-FLD & (MG / L & (MG /L \\
\hline & TION & $\begin{array}{l}\text { TOTAL } \\
\text { (FEET) }\end{array}$ & $\begin{array}{l}\text { VAL } \\
\text { (FT) }\end{array}$ & $\begin{array}{l}\text { VAL } \\
\text { (FT) }\end{array}$ & $\begin{array}{l}\text { LEVEL) } \\
(\text { FEET) }\end{array}$ & $\begin{array}{l}\text { TOTAL } \\
\text { (UG/L) }\end{array}$ & $\begin{array}{c}L A B \\
\text { (US/CM) }\end{array}$ & $\begin{array}{c}\text { AS } \\
\text { CACO31 }\end{array}$ & $\begin{array}{l}(M G / L- \\
(A C 03)\end{array}$ & $\begin{array}{c}\text { AS } \\
\text { HCO3) }\end{array}$ & $\begin{array}{l}\text { AS } \\
\mathrm{CO} 31\end{array}$ \\
\hline & $(72006)$ & $(72008)$ & $(72015)$ & $(72016)$ & $(72019)$ & $(77128)$ & $(90095)$ & $(90410)$ & $(99430)$ & $(99440)$ & $(99445)$ \\
\hline
\end{tabular}

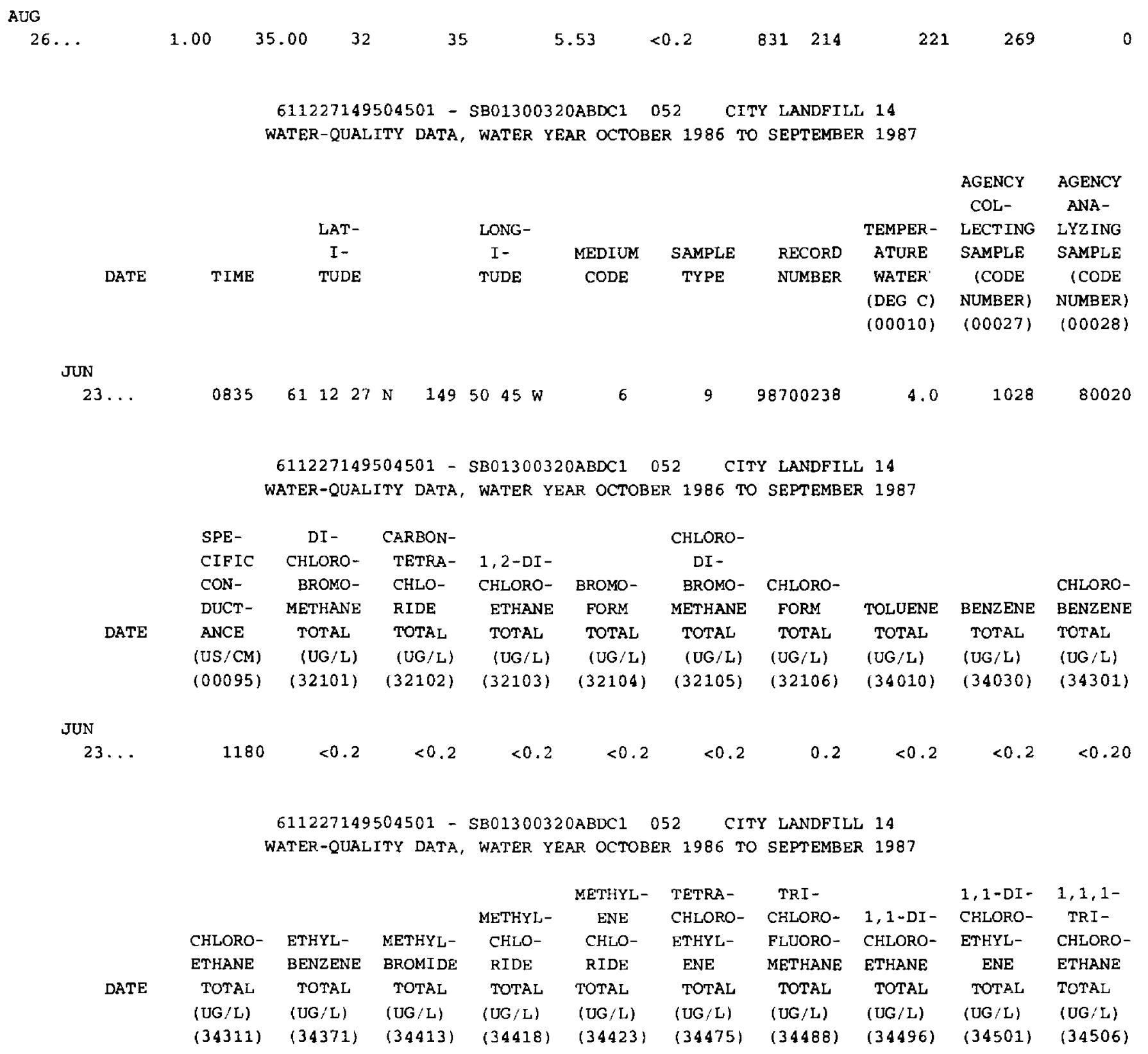

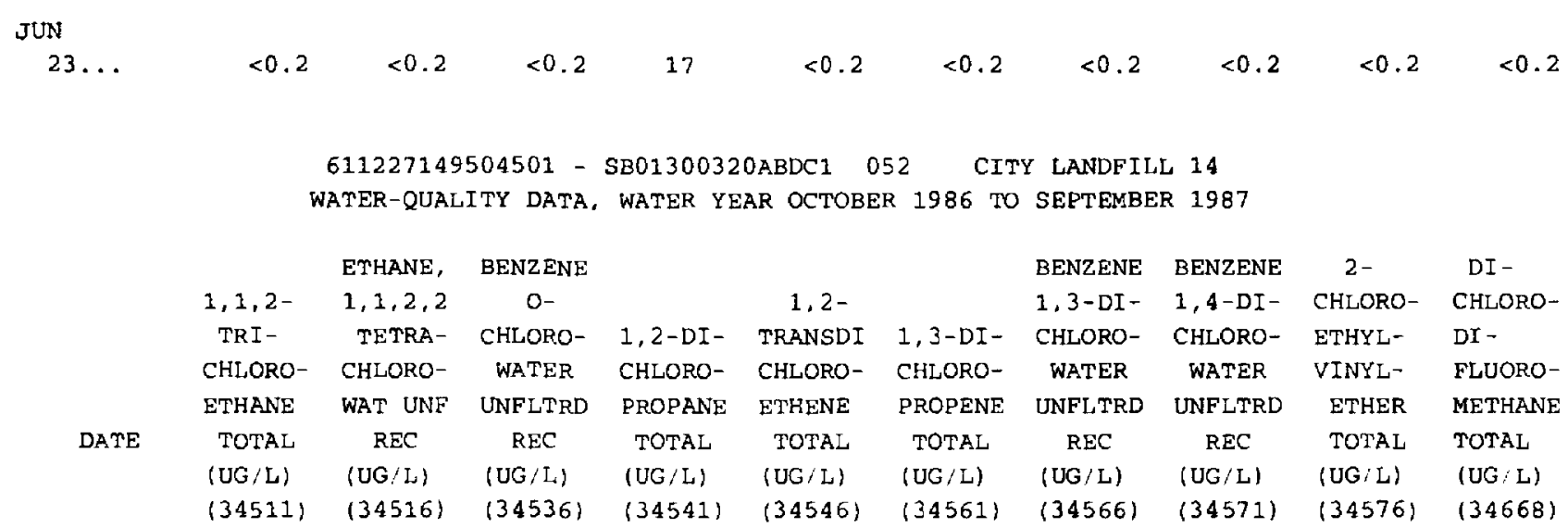




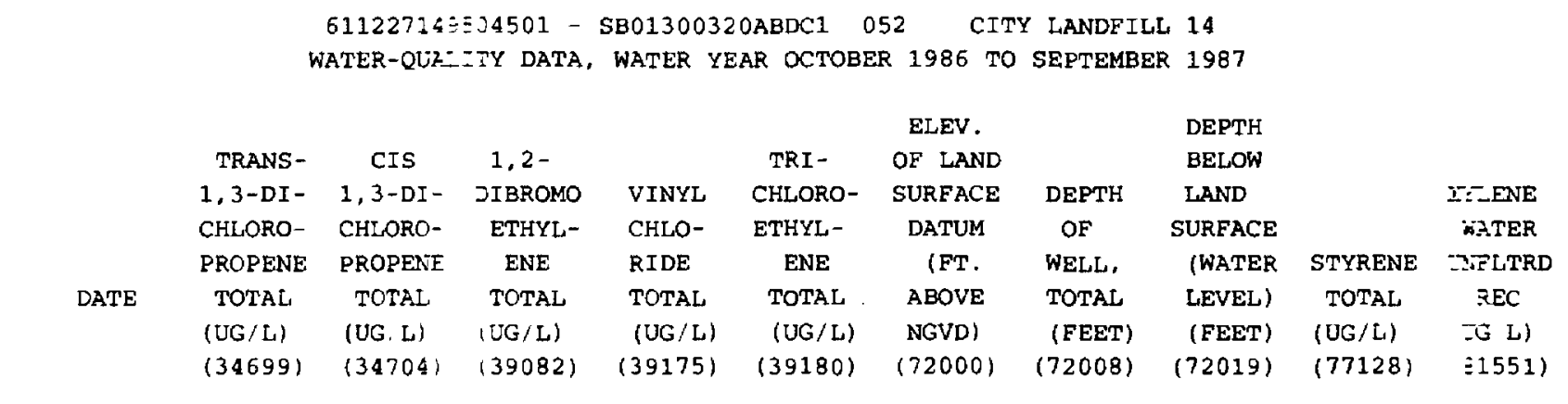

JUN

$\begin{array}{lllllllllll}23 \ldots & <0.2 & <0.2 & <0.2 & 1.9 & <0.2 & 85.1 & 20.00 & 6.50 & <0.2 & <0.20\end{array}$

$61122816 \vdots \equiv 3901$ - SB01300320ABDA1 051 CITY LANDFILL 13

WATER-QULZITY DATA, WATER YEAR OCTOBER 1986 TO SEPTEMBER 1987

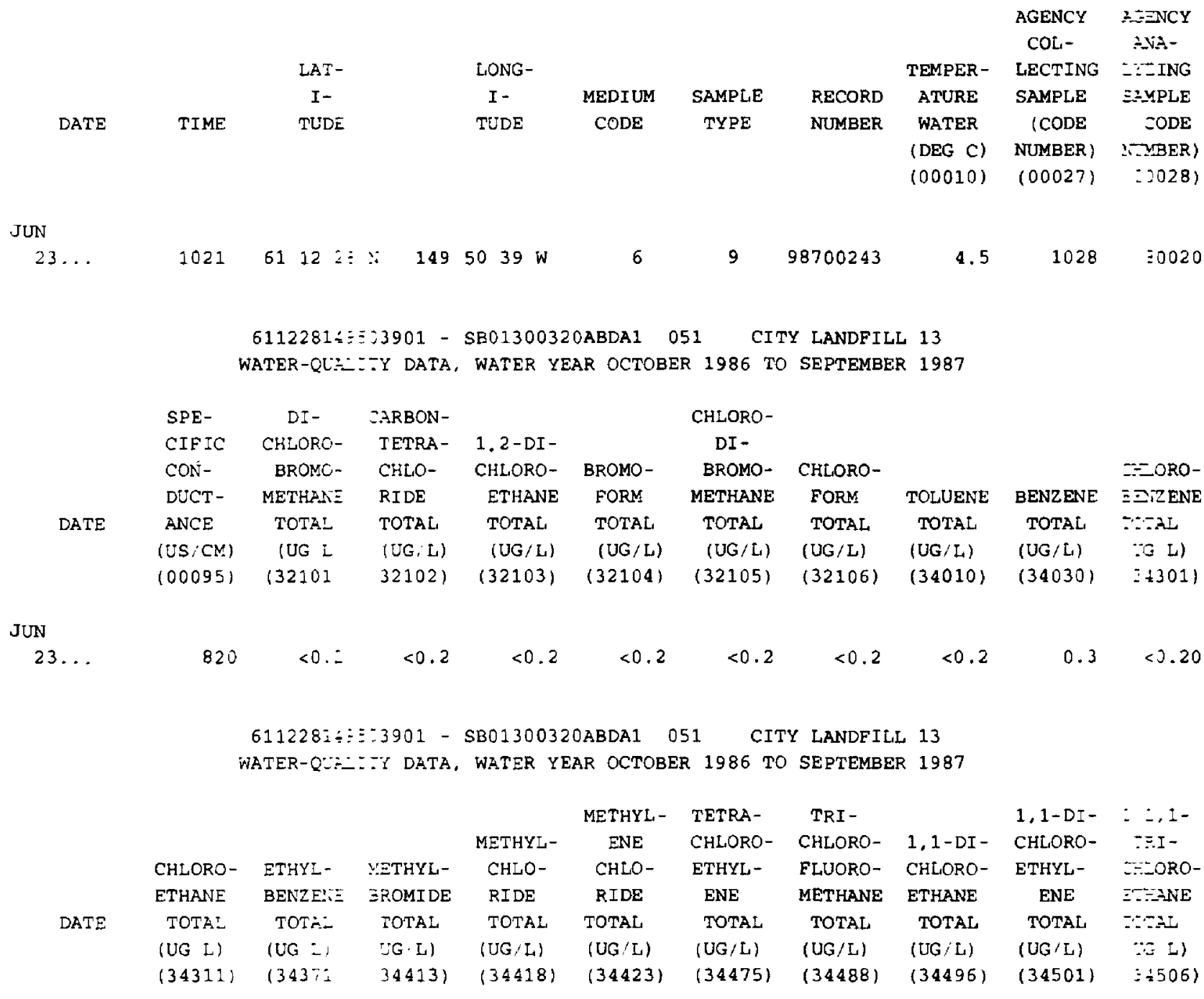

JUN

$\begin{array}{llllllll}23 & <0.2<0.2<0.2<0.2<0.2<0.2<0.2 & <0.2<0.2<0.2\end{array}$

$611228 \div \div: 3901$ - SB01300320ABDA1 051 CITY LANDFILL 13

WATER-QUE-IYY DATA, WATER YEAR OCTOBER 1986 TO SEPTEMBER 1987

\begin{tabular}{|c|c|c|c|c|c|c|c|c|c|}
\hline & ETHARE, & ZENZENE & & & & ANZENE & NE & $2-$ & $\Xi=-$ \\
\hline & $1,1,2,=$ & $0-$ & & $1,2-$ & & $1,3-\mathrm{DI}-$ & $1,4-\mathrm{DI}-$ & LORO- & $\because O R O$ \\
\hline TRI - & TETF:- & ZILORO- & $1,2-\mathrm{DI}-$ & TRANSDI & $1,3-\mathrm{DI}-$ & CHLORO- & CHIORO- & ETHYL,- & $\Xi \Sigma-$ \\
\hline HLORO- & CHLORC - & NATER & CHLORO- & CHLORO- & CHLORO- & WATE & WATER & VINYL - & \\
\hline i & AT DA: & XFLTRD & PROPANE & ETHENE & PROPENE & UNFLTRD & UNFLTRD & ETHER & \\
\hline TOTAL & REC & $\mathrm{REC}$ & TOTAL & TOTAL & TOTAL & REC & REC & TOTAL & i \\
\hline (UG L) & (UG 2$)$ & JG L) & (UG,L) & $(U G / L)$ & $(U G / L)$ & (UG/L) & $(U G / L)$ & $(U G, L)$ & E) \\
\hline$\{34511\}$ & $13451=$ & 345361 & (34541) & $\{34546\}$ & $(34561)$ & $(34566)$ & $(34571)$ & $(34576)$ & $\div 568$ \\
\hline
\end{tabular}

JUN

$23 \ldots<<<<<<0.2<0.20<0.2<0.20<0.20<0.20<<0.2<0.2$ 


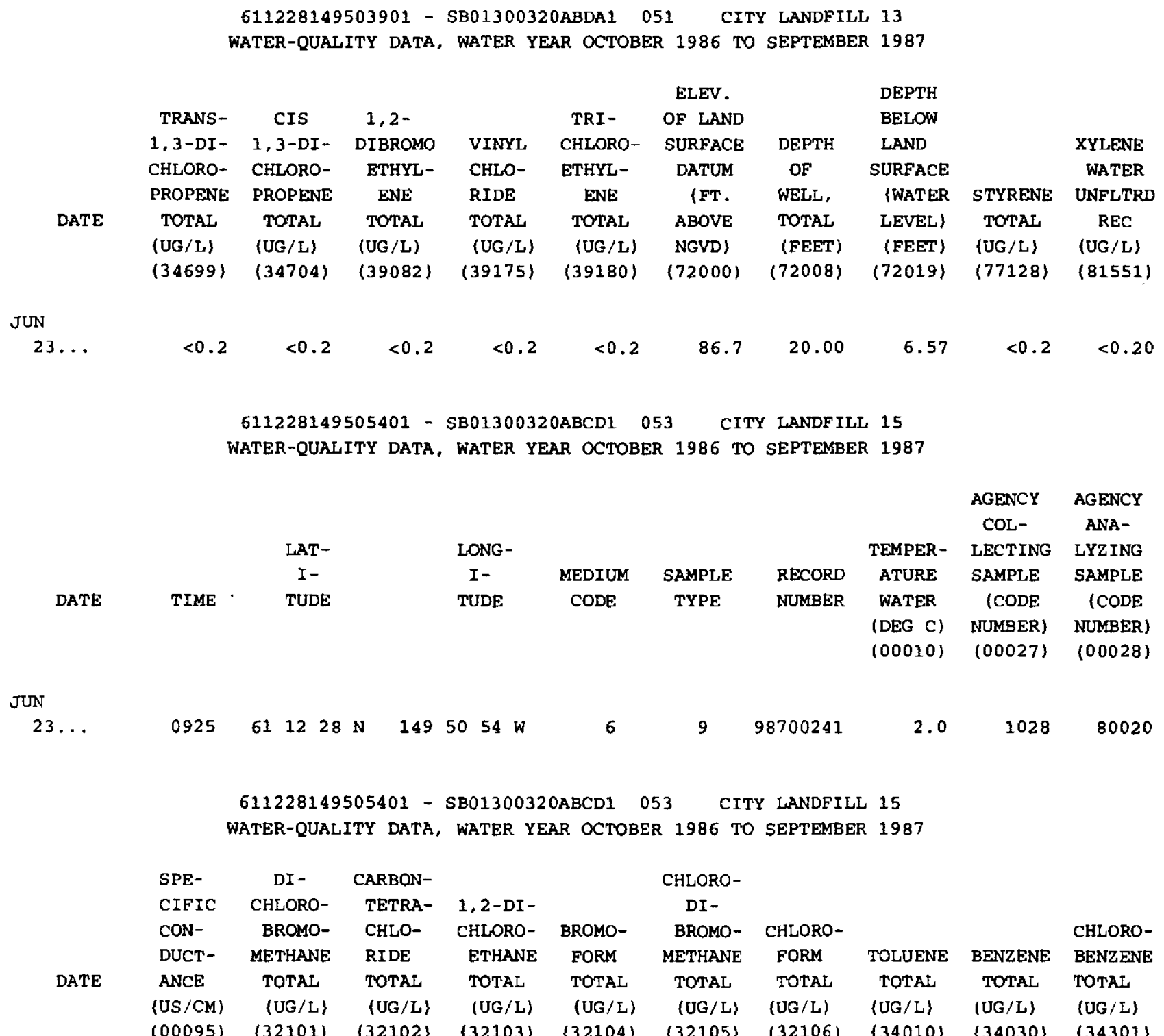

JUN

$\begin{array}{lllllllllll}23 \ldots & 560 & <0.2 & <0.2 \quad<0.2 & <0.2 & <0.2 & <0.2 & <0.2 & 0.5 & <0.20\end{array}$

611228149505401 - SB01300320ABCD1 053 CITY LANDFILL 15

WATER-QUALITY DATA，WATER YEAR OCTOBER 1986 TO SEPTEMBER 1987

\begin{tabular}{cccccccccccc} 
& & & & \multicolumn{3}{c}{ METHYL- } & TETRA- & TRI- & 1,1-DI- & $1,1,1-$ \\
& & & & & METHYL- & ENE & CHLORO- & CHLORO- & $1,1-D I-$ & CHLORO- & TRI- \\
& CHLORO- & ETHYL- & METHYL- & CHLO- & CHLO- & ETHYL- & FLUORO- & CHLORO- & ETHYL- & CHLORO- \\
DATE & ETHANE & BENZENE & BROMIDE & RIDE & RIDE & ENE & METHANE & ETHANE & ENE & ETHANE \\
& TOTAL & TOTAL & TOTAL & TOTAL & TOTAL & TOTAL & TOTAL & TOTAL & TOTAL & TOTAL \\
& $(U G / L)$ & $(U G / L)$ & $(U G / L)$ & $(U G / L)$ & $(U G / L)$ & $(U G / L)$ & $(U G / L)$ & $(U G / L)$ & $(U G / L)$ & $(U G / L)$ \\
& $(3431)$ & $(34371)$ & $(34413)$ & $(34418)$ & $(34423)$ & $(34475)$ & $(34488)$ & $(34496)$ & $(34501)$ & $(34506)$
\end{tabular}

JUN

$\begin{array}{lllllllllll}23 & < & <.2 & <0.2 & <0.2 & <0.2 & <0.2 & <0.2 & <0.2 & <0.2 & <0.2<<<0.2\end{array}$

611228149505401 - SB01300320ABCD1 053 CITY LANDFILI 15

WATER-QUALITY DATA, WATER YEAR OCTOBER 1986 TO SEPTEMBER 1987

$\begin{array}{ccccccccccc} & \text { ETHANE, } & \text { BENZENE } & & & & \text { BENZENE } & \text { BENZENE } & 2- & \text { DI- } \\ 1,1,2- & 1,1,2,2 & \text { O- } & & 1,2- & & 1,3-D I- & 1,4-D I- & \text { CHLORO- } & \text { CHLORO- } \\ \text { TRI- } & \text { TETRA- } & \text { CHLORO- } & 1,2-D I- & \text { TRANSDI } & 1,3-D I- & \text { CHLORO- } & \text { CHLORO- } & \text { ETHYL- } & \text { DI- } \\ \text { CHLORO- } & \text { CHLORO- } & \text { WATER } & \text { CHLORO- } & \text { CHLORO- } & \text { CHLORO- } & \text { WATER } & \text { WATER } & \text { VINYL- } & \text { FLUORO- } \\ \text { ETHANE } & \text { WAT UNF } & \text { UNFLTRD } & \text { PROPANE } & \text { ETHENE } & \text { PROPENE } & \text { UNFLTRD } & \text { UNFLTRD } & \text { ETHER } & \text { METHANE } \\ \text { TOTAL } & \text { REC } & \text { REC } & \text { TOTAL } & \text { TOTAL } & \text { TOTAL } & \text { REC } & \text { REC } & \text { TOTAL } & \text { TOTAL } \\ (U G / L) & (U G / L) & (U G / L) & (U G / L) & (U G / L) & (U G / L) & (U G / L) & (U G / L) & (U G / L) & (U G / L) \\ (34511) & (34516) & (34536) & (34541) & (34546) & (34561) & (34566) & (34571) & (34576) & (34668)\end{array}$

JUN

$\begin{array}{lllllllll}23 & <0.2<0.2<0.20 & <0.2 & <0.2 & <0.20 & <0.20 & <0.20 & <0.2 & 0.2\end{array}$ 


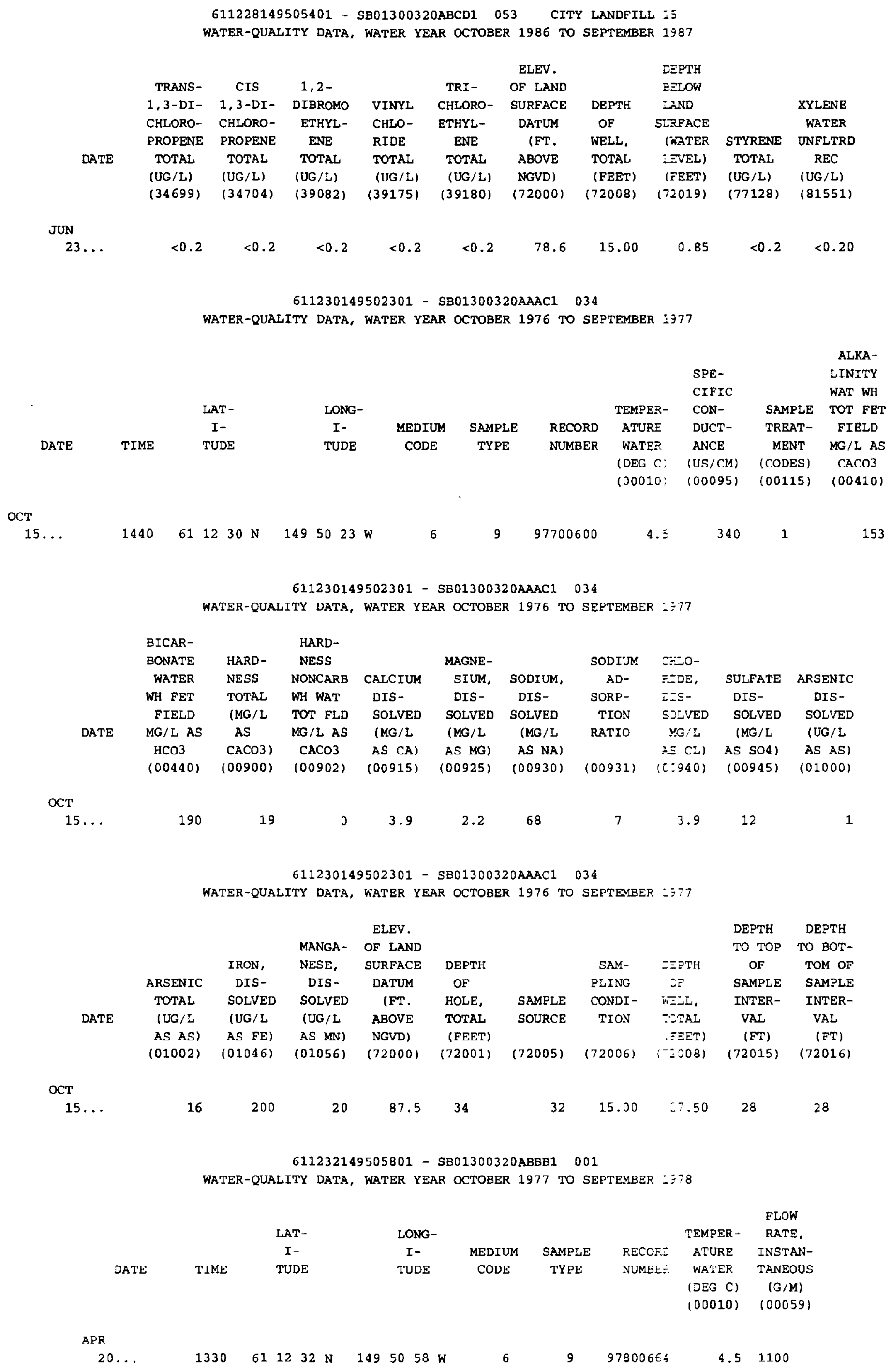


611232149505801 - SB01300320ABBB1 001 WATER-QUALITY DATA, WATER YEAR OCTOBER 1977 TO SEPTEMBER 1978

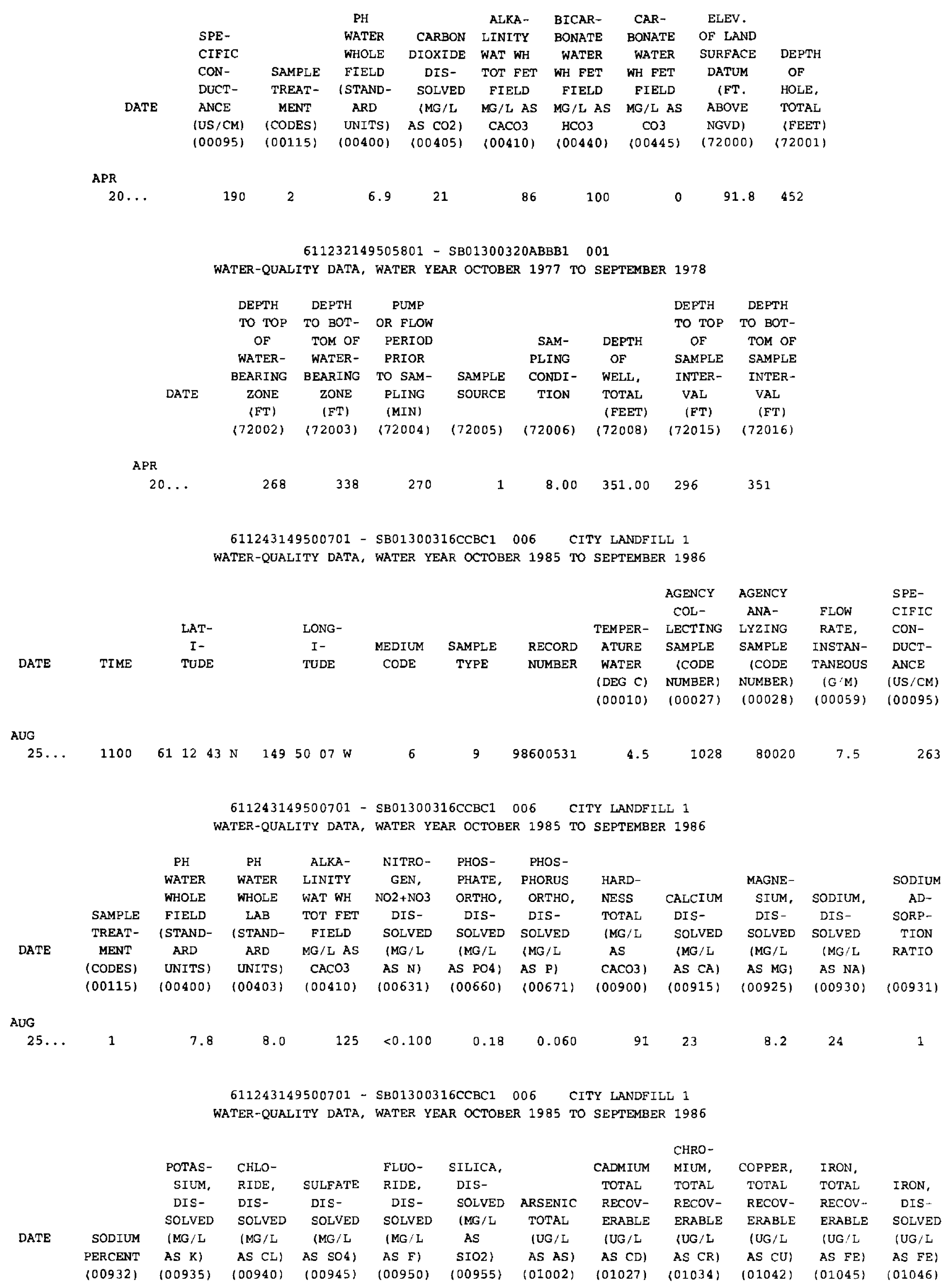

AUG

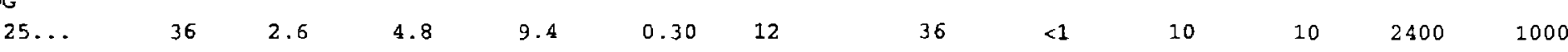


611243149500701 - SB01300316CCBC1 006 CITY LANDFILL 1

WATER-QUALITY DATA, WATER YEAR OCTOBER 1985 TO SEPTEMBER 1986

\begin{tabular}{|c|c|c|c|c|c|c|c|c|c|c|c|c|}
\hline & $\begin{array}{l}\text { LEAD, } \\
\text { TOTAL }\end{array}$ & $\begin{array}{l}\text { KANGA- } \\
\text { NESE, } \\
\text { IOTAL }\end{array}$ & $\begin{array}{l}\text { MANGA- } \\
\text { NESE, }\end{array}$ & $\begin{array}{l}\text { NICKEL, } \\
\text { TOTAL }\end{array}$ & $\begin{array}{l}\text { ZINC, } \\
\text { TOTAI }\end{array}$ & ANTI & $\begin{array}{c}\text { DI- } \\
\text { CHLORO- }\end{array}$ & $\begin{array}{l}\text { CARBON- } \\
\text { TETRA- }\end{array}$ & $1,2-D I-$ & & $\begin{array}{c}\text { CHLORO- } \\
\text { DI - }\end{array}$ & \\
\hline & $\begin{array}{l}\text { RECOV- } \\
\text { ERABLE } \\
\text { (UG/L }\end{array}$ & $\begin{array}{l}\text { RECOV- } \\
\text { ERABLE } \\
\text { (UG } / \mathrm{L}\end{array}$ & $\begin{array}{l}\text { DIS- } \\
\text { SOLVED } \\
\text { IUG/L }\end{array}$ & $\begin{array}{l}\text { RECOV- } \\
\text { ERABLE } \\
\text { (UG/L }\end{array}$ & $\begin{array}{l}\text { RECOV- } \\
\text { ERABLE } \\
\text { (UG /L }\end{array}$ & $\begin{array}{l}\text { MONY, } \\
\text { TOTAL } \\
\text { (UG / L }\end{array}$ & $\begin{array}{l}\text { BROMO- } \\
\text { METHANE } \\
\text { TOTAL }\end{array}$ & $\begin{array}{l}\text { CHLO- } \\
\text { RIDE } \\
\text { TOTAI }\end{array}$ & $\begin{array}{l}\text { CHLORO- } \\
\text { ETHANE } \\
\text { TOTAL }\end{array}$ & $\begin{array}{l}\text { BROMO- } \\
\text { FORM } \\
\text { TOTAL }\end{array}$ & $\begin{array}{l}\text { BROMO- } \\
\text { METHANE } \\
\text { TOTAL }\end{array}$ & $\begin{array}{l}\text { CHLORO- } \\
\text { FORM } \\
\text { TOTAL }\end{array}$ \\
\hline \multirow{2}{*}{ ATE } & $A S P B)$ & AS MN) & AS MN) & AS NI) & AS $\mathrm{ZN}$ ) & AS SB) & (UG/L) & (UG / L) & (UG /L) & (UG/L) & (UG / L) & (UG /L) \\
\hline & $(01051)$ & $31055)$ & $(01056)$ & $(01067)$ & $(01092)$ & $(01097)$ & $(32101)$ & $(32102)$ & $(32103)$ & $(32104)$ & $(32105)$ & $(32106)$ \\
\hline
\end{tabular}

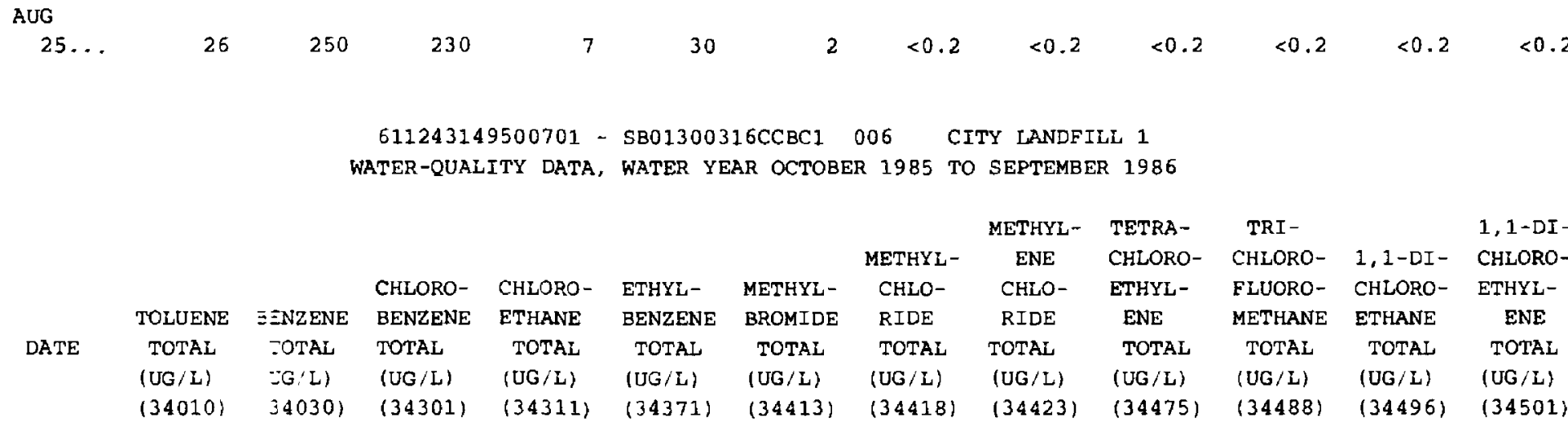

AUS

\begin{tabular}{|c|c|}
\hline $25 \ldots$ & $<0.2$ \\
\hline
\end{tabular}

611243149500701 - SB01300316CCBC1 006 CITY LANDFILL 1 WATER-QUALITY DATA, WATER YEAR OCTOBER 1985 TO SEPTEMBER 1986

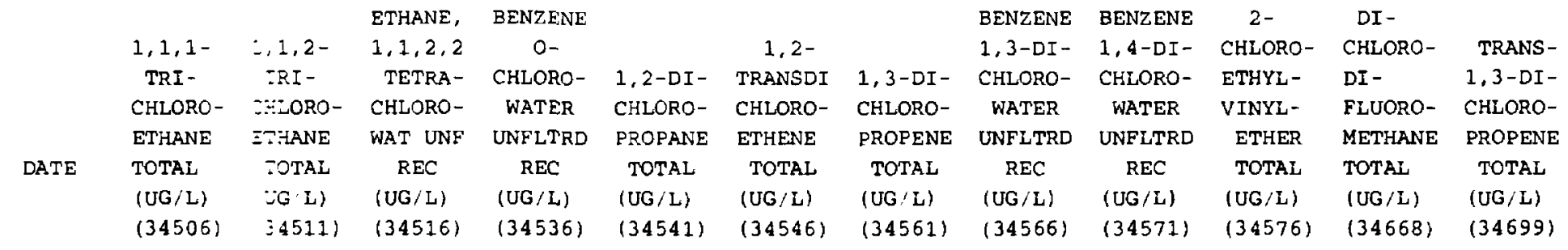

AUG

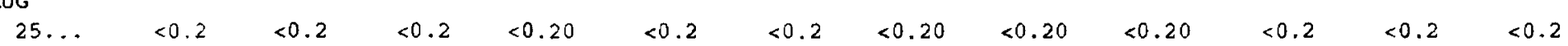

611243149500701 - \$B01300316CCBC1 006 CITY LANDFILL 1

WATER-QUALITY DATA, WATER YEAR OCTOBER 1985 TO SEPTEMBER 1986

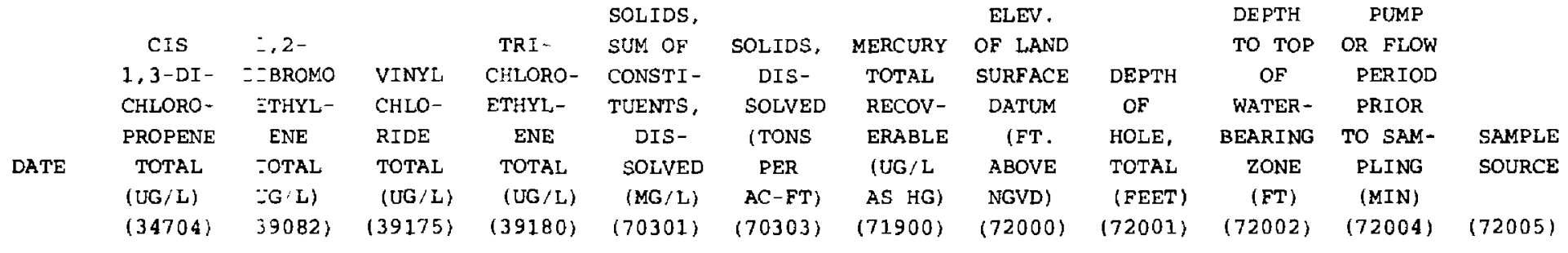

AUG

$\begin{array}{llllllllllll}25 \ldots & <0.2 & <0.2 & <0.2 & <0.2 & 160 & 0.22 & 0.30 & 101 & 95 & 91\end{array}$

611243149500701 - SB01300316CCBC1 006 CITY LANDFILL WATER-QUALITY DATA, WATER YEAR OCTOBER 1985 TO SEPTEMBER 1986

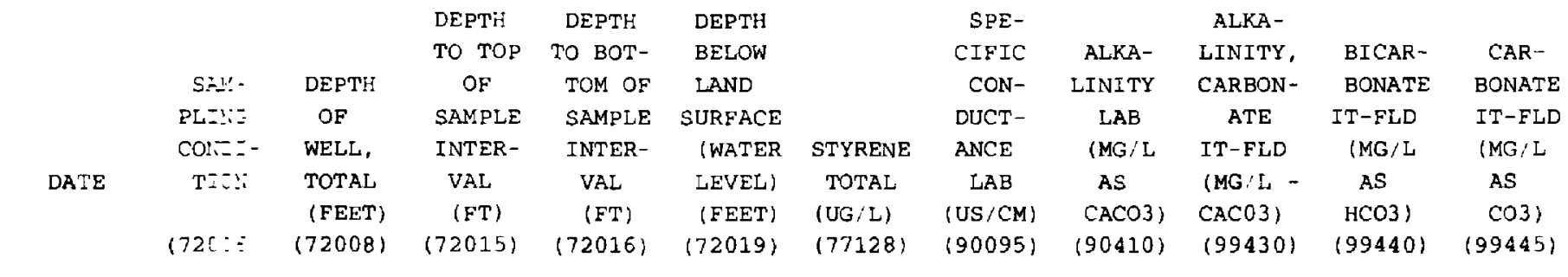

AUG

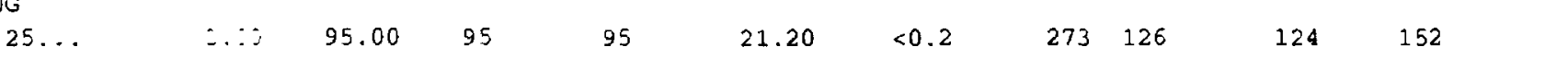


611243149500702 - SB01300316CCBC2 006 CITY LANDFILL 2 WATER-QUALITY DATA, WATER YEAR OCTOBER 1985 TO SEPTEMBER 1986

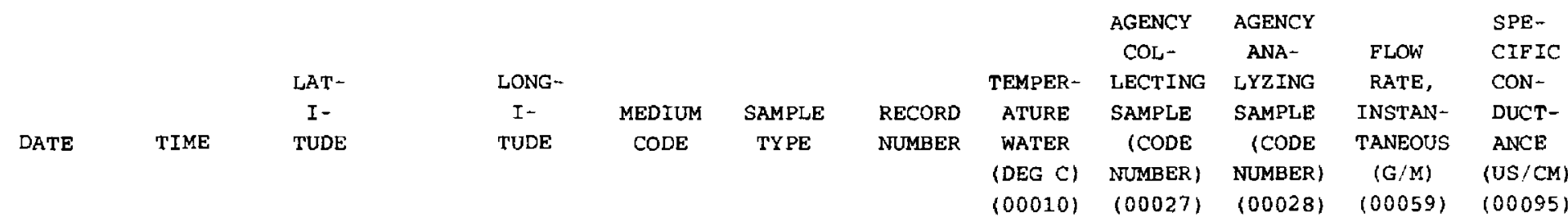

AUG

$\begin{array}{lllllllllllllll}25 \ldots & 1230 & 61 & 12 & 43 \mathrm{~N} & 149 & 50 & 07 \mathrm{~W} & 6 & 9 & 98600532 & 5.0 & 1028 & 80020 & 7.5\end{array}$

611243149500702 - SB01300316CCBC2 006 CITY LANDFILL 2 WATER-QUALITY DATA, WATER YEAR OCTOBER 1985 TO SEPTEMBER 1986

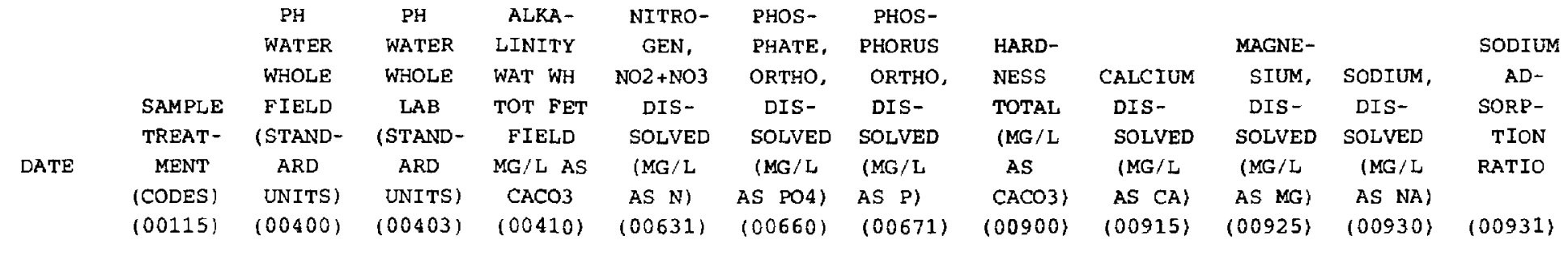

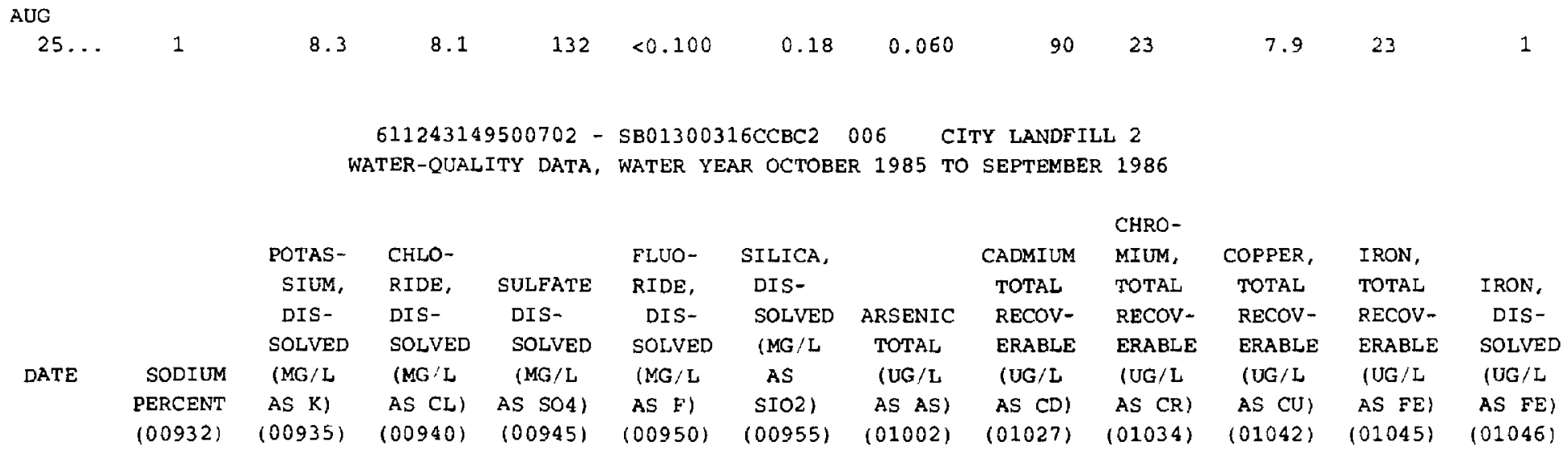

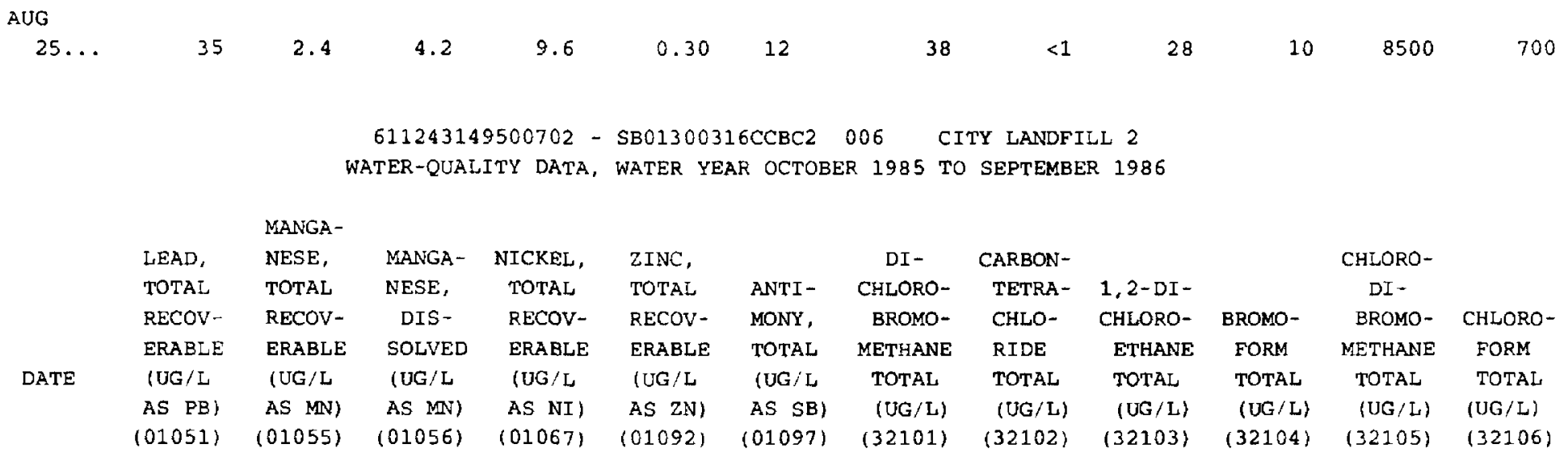

AUG

$\begin{array}{lllllllllllllll}25 \ldots & 10 & 320 & 210 & 7 & 30 & 1 & <0.2 & <0.2 & <0.2 & <0.2 & <0.2 & <0.2\end{array}$

611243149500702 - SB01300316CCBC2 006 CITY LANDFILL 2

WATER-QUALITY DATA, WATER YEAR OCTOBER 1985 TO SEPTEMBER 1986

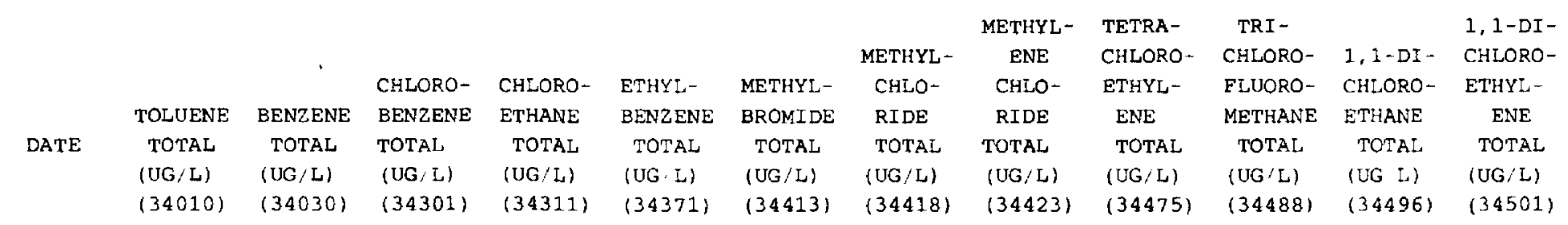

AUG

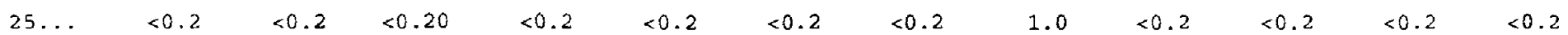


611243149500702 - SB01300316CCBC2 006 CITY LANDFILL 2

WATER-QUALITY DATA, WATER YEAR OCTOBER 1985 TO SEPTEMBER 1986

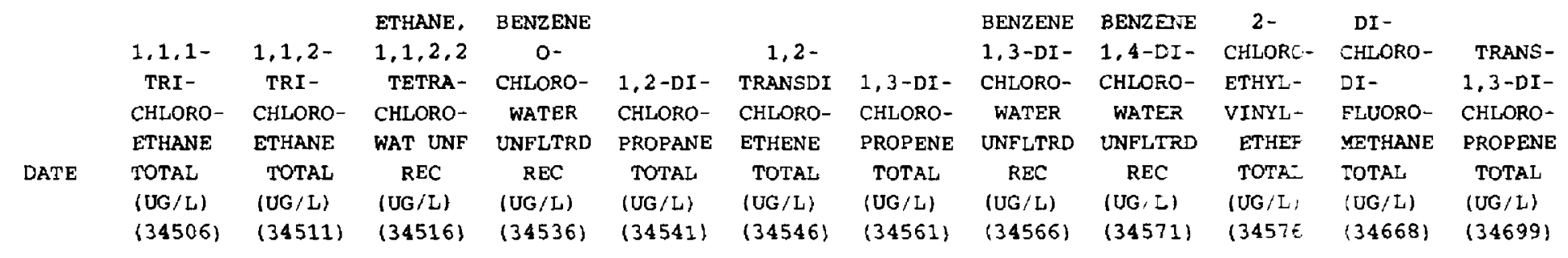

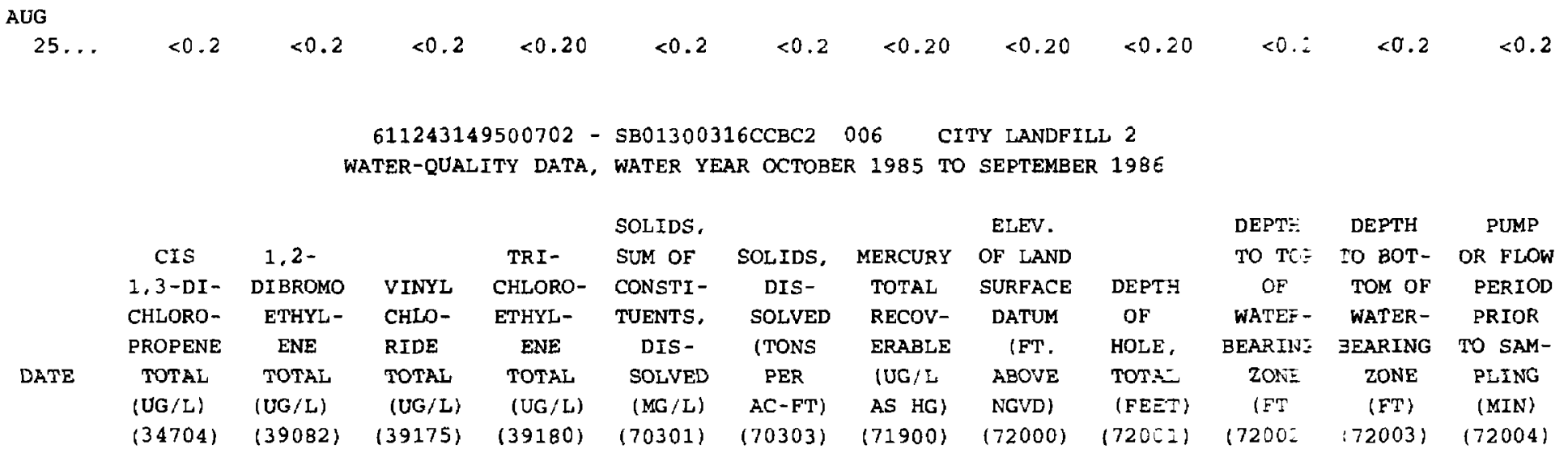

AUC

$\begin{array}{llllllllllll}25 & < & <0.2 & <0.2 & 0.4 & <0.2 & 162 & 0.22 & <0.10 & 101 & 70 & \vdots\end{array}$

611243149500702 - SB01300316CCBC2 006 CITY LANDFILL 2

WATER-QUALITY DATA, WATER YEAR OCTOBER 1985 TO SEPTEMBER 198

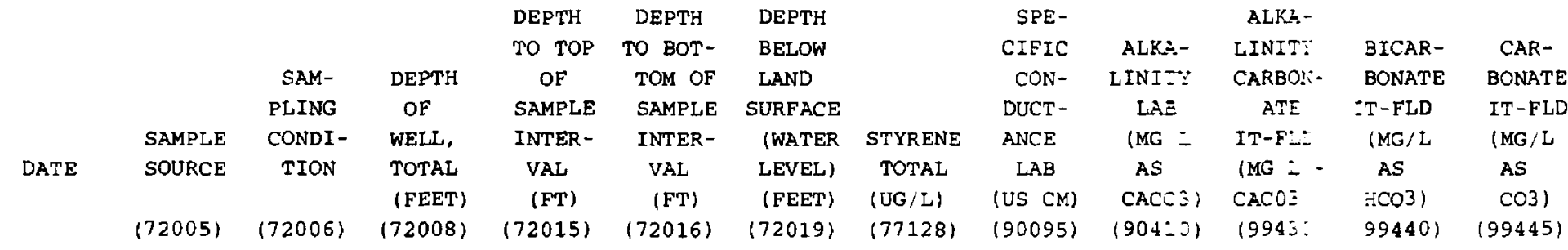

AUC

$\begin{array}{lllllllllllll}25 \ldots & 1 & 1.00 & 70.00 & 70 & 70 & 20.50 & <0.2 & 269 & 125 & 131 & : 60 & 0\end{array}$

611243149500703 - SB01300316CCBC3 006 CITY LANDFILL 3

WATER-QUALITY DATA, WATER YEAR OCTOBER 1985 TO SEPTEMBER 198

\begin{tabular}{|c|c|c|c|c|c|c|c|c|c|c|c|}
\hline & & & & & & & & $\begin{array}{l}\text { AGENC: } \\
\text { COL - }\end{array}$ & $\begin{array}{c}\text { AGEHC: } \\
\text { ANÁ- }\end{array}$ & FLOW & $\begin{array}{l}\text { SPE- } \\
\text { CIFIC }\end{array}$ \\
\hline
\end{tabular}

AUG

$\begin{array}{lllllllllllllllll}25 \ldots & 1430 & 61 & 12 & 43 \mathrm{~N} & 149 & 50 & 07 \mathrm{~W} & 6 & 9 & 98600530 & 7.5 & 1: 28 & 80::: & 1.0 & 6090\end{array}$

611243149500703 - SB01300316CCBC3 006 CITY LANDEILL 3

WATER-QUALITY DATA, WATER YEAR OCTOBER 1985 TO SEFTEMBER $198 \Xi$

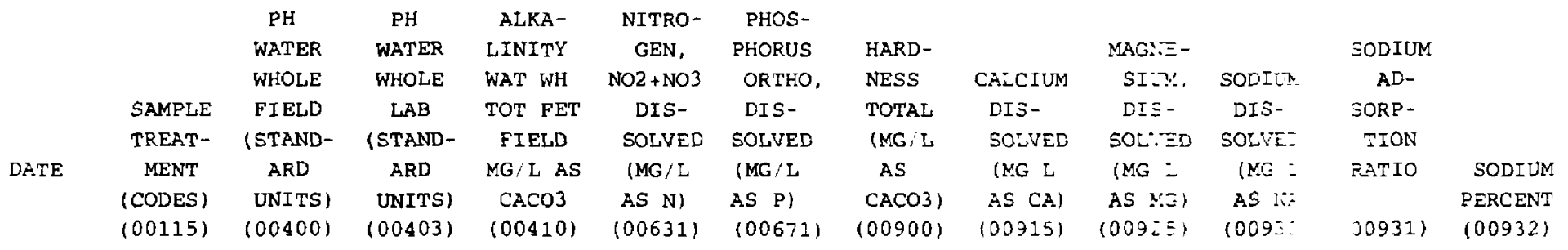

AUG

$25 \ldots$

$\begin{array}{llllllll}6.8 & 6.8 & 2600 & <0.100 & <0.010 \quad 2800 & 420 & 180 & 580\end{array}$

580

40 
611243149500703 - SB01300316CCBC3 006 CITY LANDFILL 3

WATER-QUALITY DATA, WATER YEAR OCTOBER 1985 TO SEPTEMBER 1986

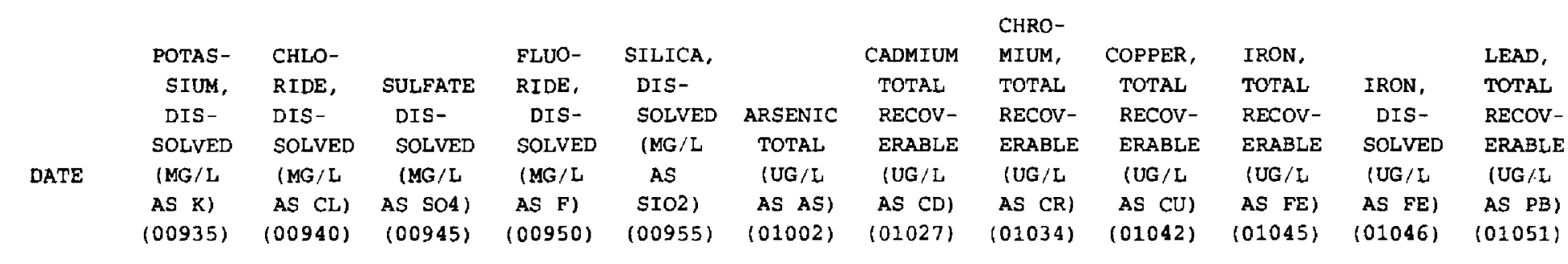

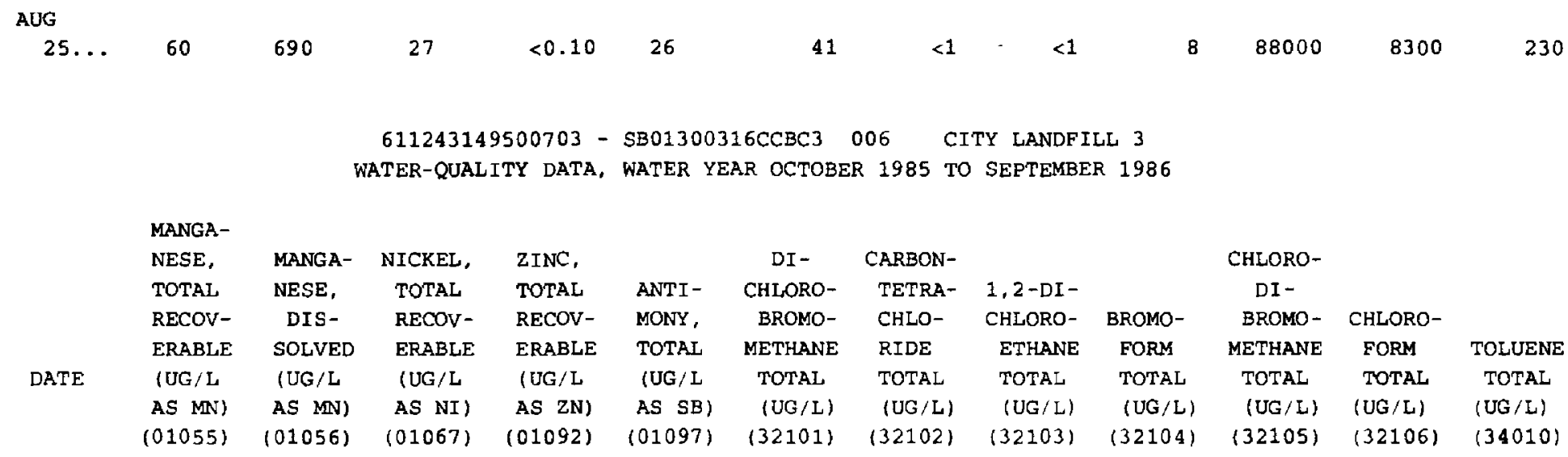

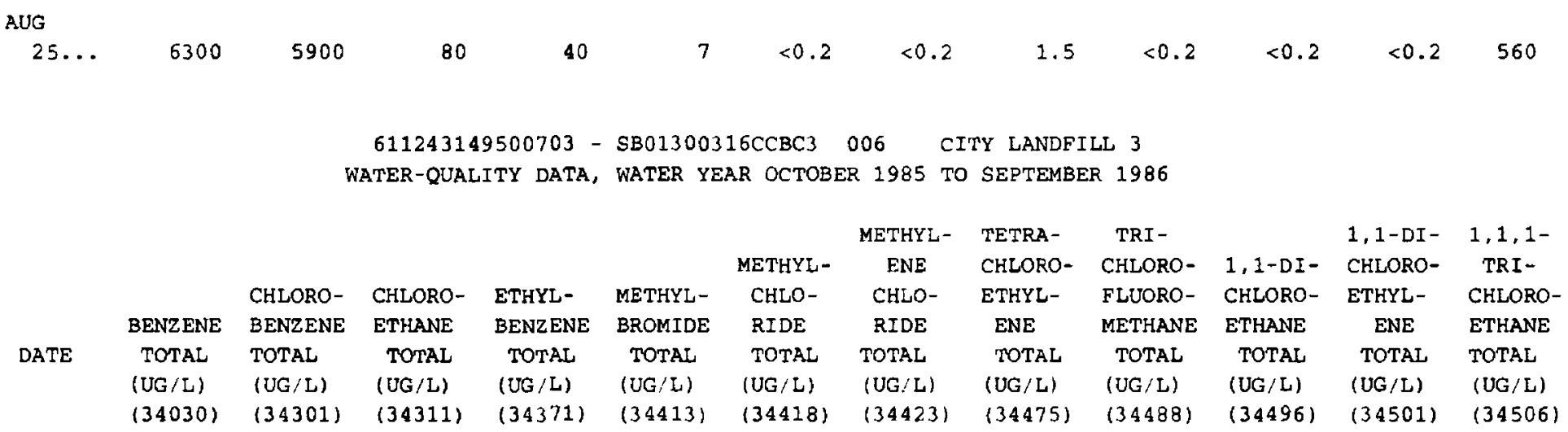

$\mathrm{AU}$

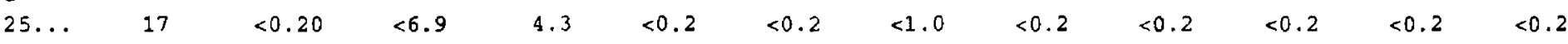

611243149500703 - SB01300316CCBC3 006 CITY LANDFILL

WATER-QUALITY DATA, WATER YEAR OCTOBER 1985 TO SEPTEMBER 1986

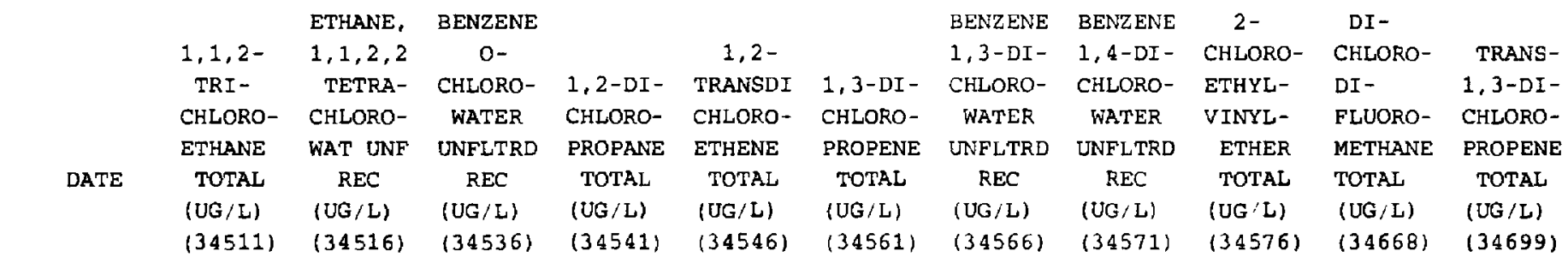

AUG

$\begin{array}{lllllllllll}25 \ldots & <0.2 & <0.2 & <0.20 & 0.5 & 6.9 & <0.20 & <0.20 & <0.20 & <0.2<<0.2 & <0.2\end{array}$

611243149500703 - SB01300316CCBC3 006 CITY LANDFILL 3

WATER-QUALITY DATA, WATER YEAR OCTOBER 1985 TO SEPTEMBER 1986

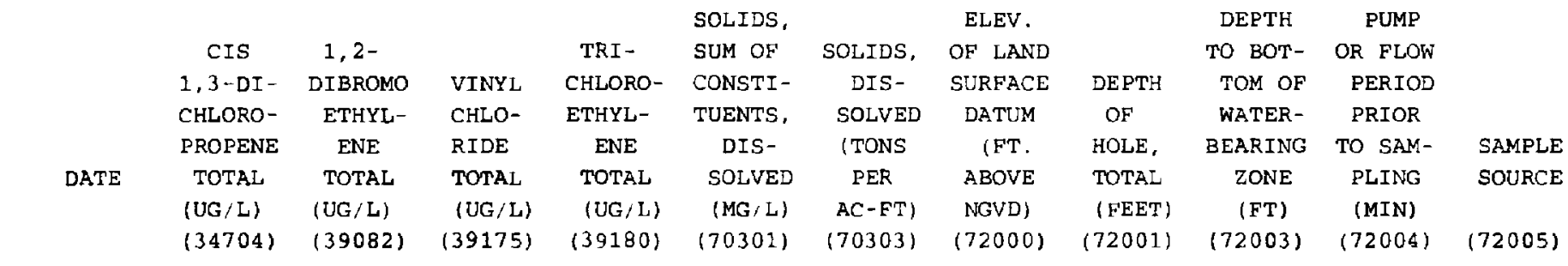

AUG

$\begin{array}{llllllllllll}25 \ldots & <0.2 & <0.2 & 46 & 0.7 & 3570 & 4.85 & 102 & 19 & 23 & 50 & 1\end{array}$ 


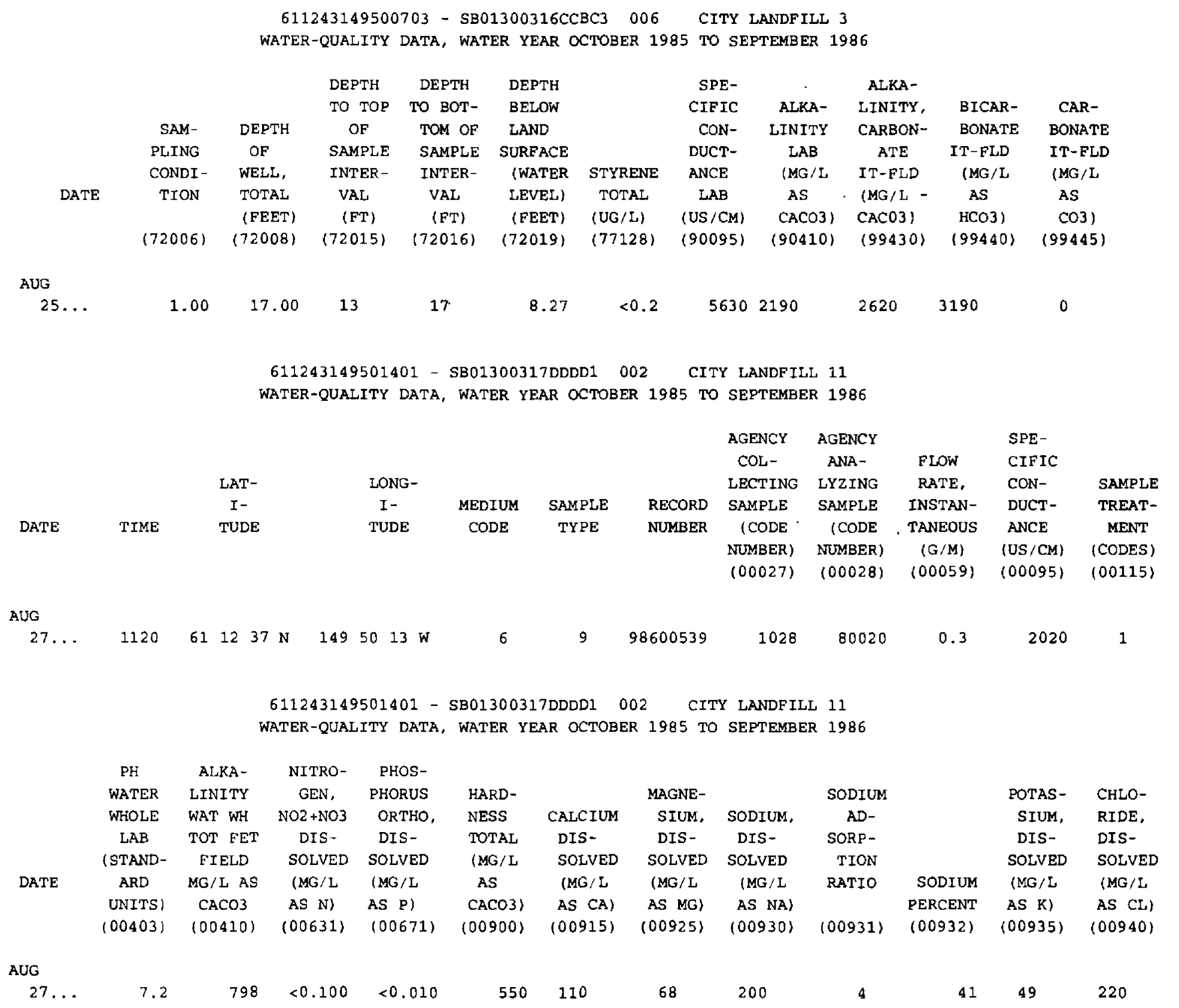

611243149501401 - SB01300317DDDD1 002 CITY LANDFILL 11 WATER-QUALITY DATA, WATER YEAR OCTOBER 1985 TO SEPTEMBER 1986

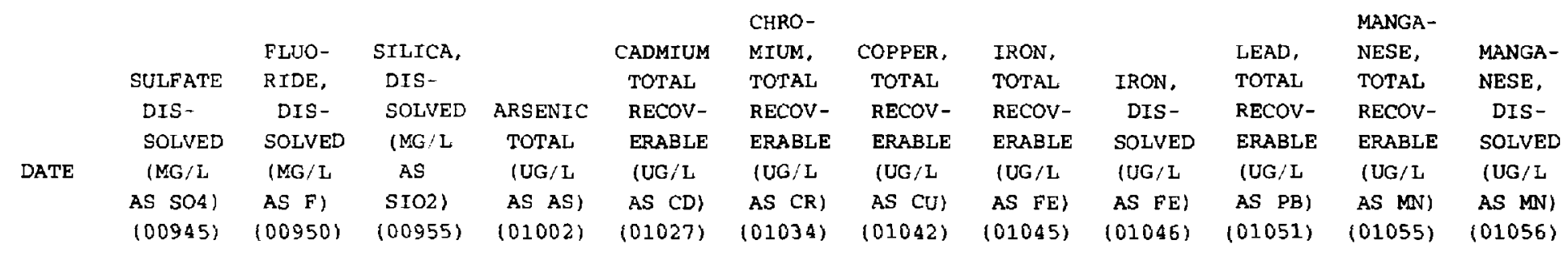

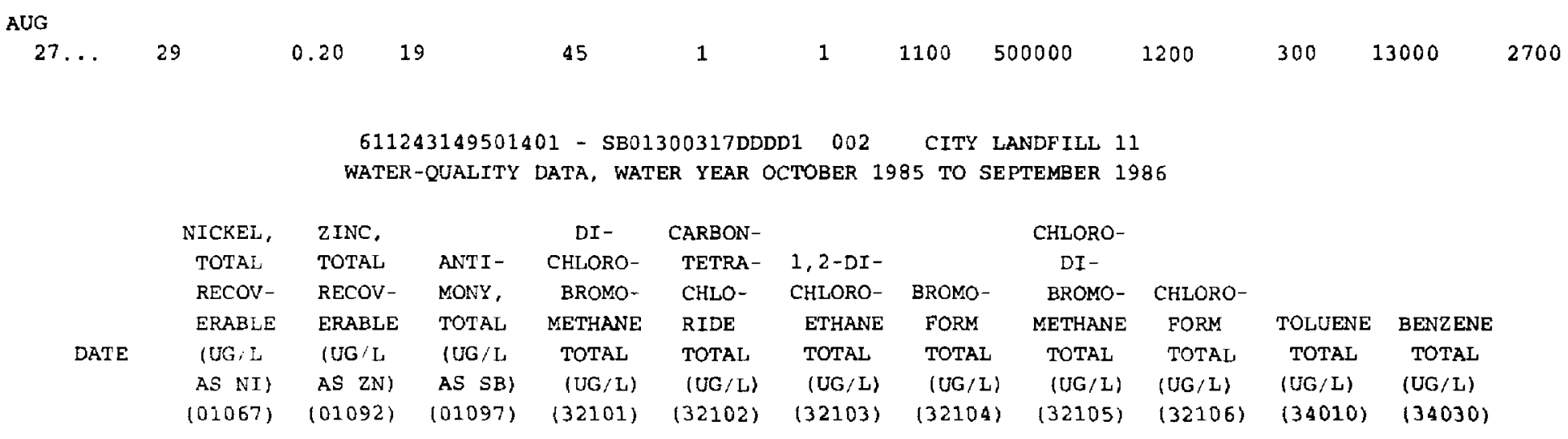




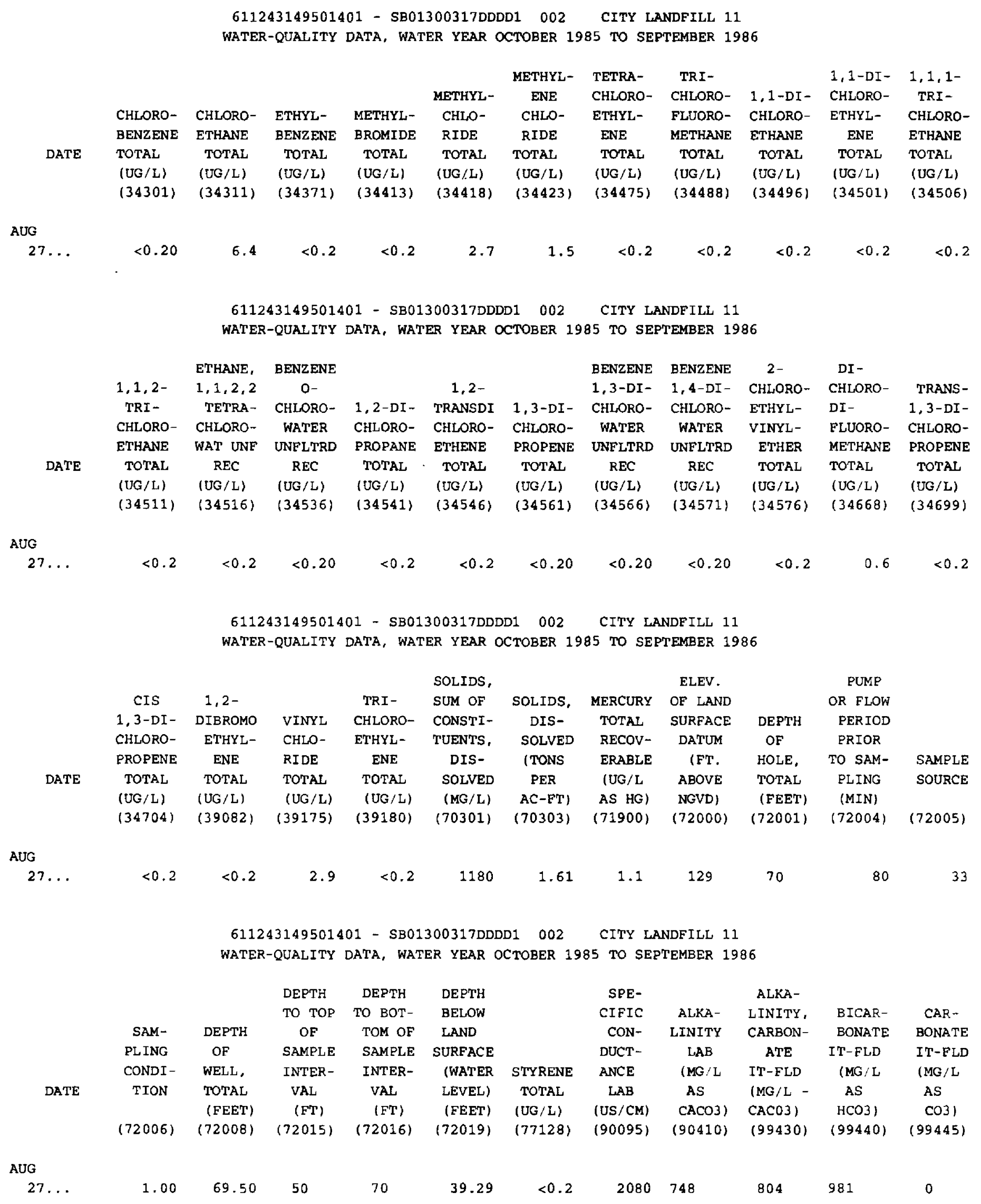

611243149504801 - SB01300317DCDC1 011 CITY LANDFILL 12 WATER-QUALITY DATA, WATER YEAR OCTOBER 1985 TO SEPTEMBER 1986

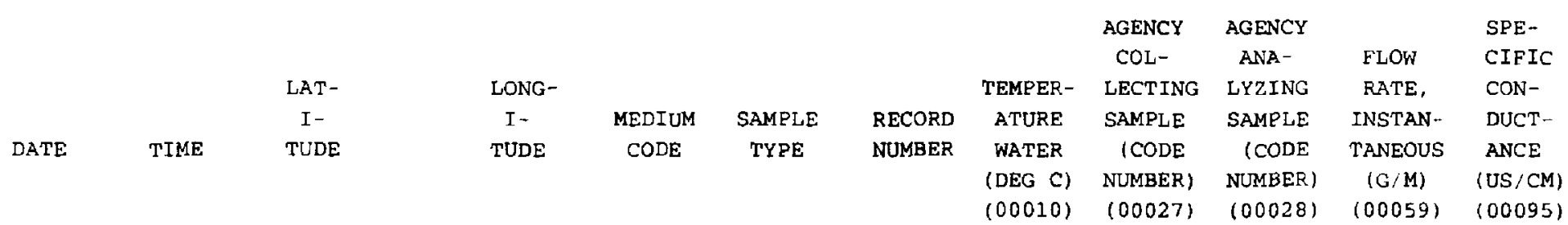


611243149504801 - $\subseteq \equiv 01300317 D C D C 1011$ CITY LANDFILL 12

WATER-QUALITY DATA, WATER YEAR OCTOBER 1985 TO SEPTEMBER 1986

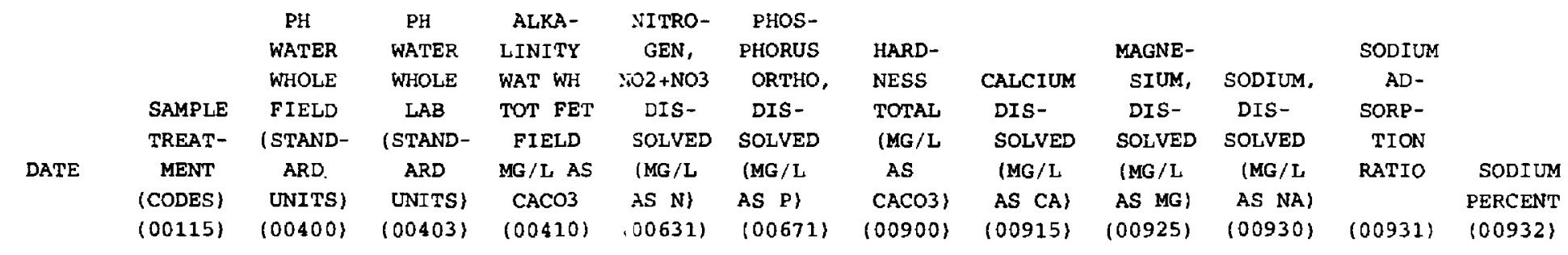

AUG

$\begin{array}{lllllllllllllll}27 \ldots & 1 & 6.2 & 6.4 & 1130 & <0.100 & <0.010 & 1200 & 340 & 80 & 56 & 0.7\end{array}$

611243149504801 - $\Xi \equiv J 1300317 D C D C 1011$ CITY LANDEILL 12

WATER-QUALITY DATA, WATER YEAR OCTOBER 1985 TO SEPTEMBER 1986

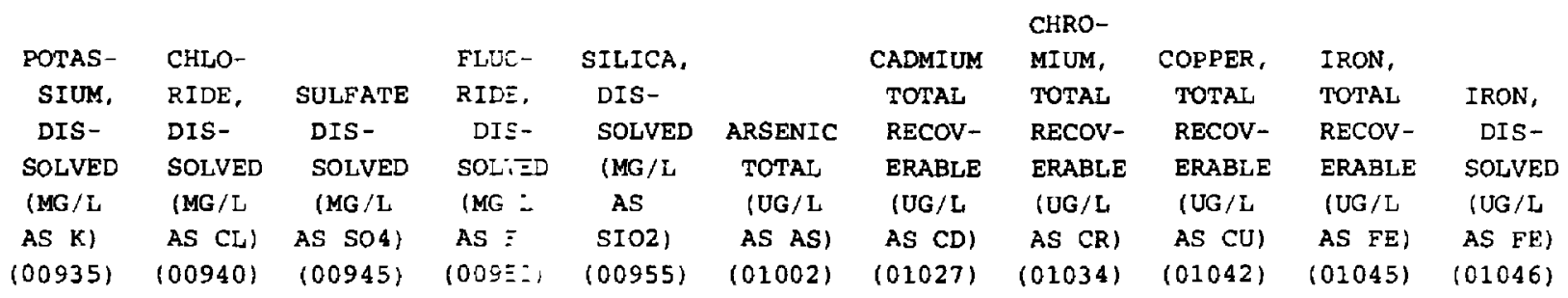

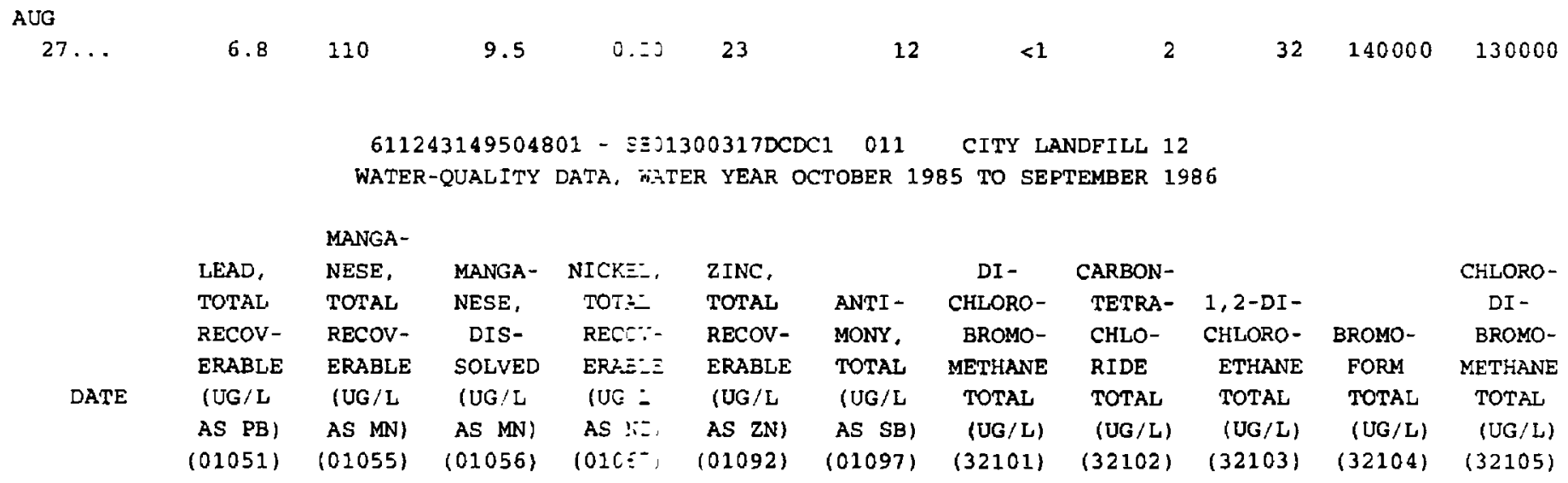

AUG

$\begin{array}{lllllllllll}27 \ldots & < & 59000 & 56000 & \div & 70 & 1 & <0.2 & <0.2 & 1.0 & <0.2<\end{array}$

611243149504801 - $\equiv \equiv: 1300317 D C D C 1011$ CITY LANDFILL 12

WATER-QUALITY DATA, WATER YEAR OCTOBER 1985 TO SEPTEMBER 1986

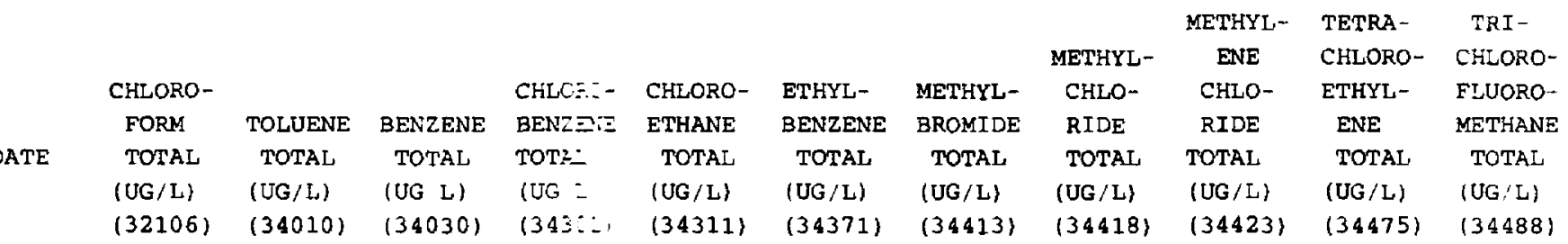

AUG

$\begin{array}{llllllllllll}27 \ldots & 0.6 & 440 & 4.7 & <C .: & 13 & 3.3 & <0.2 & 1.3 & 210 & 0.4 & 4.5\end{array}$

611243149504801 - $\equiv \equiv: 1300317 D C D C 1011$ CITY LANDFILL 12

WATER-QUALITY DATA, Ti:TER YEAR OCTOBER 1985 TO SEPTEMBER 1986

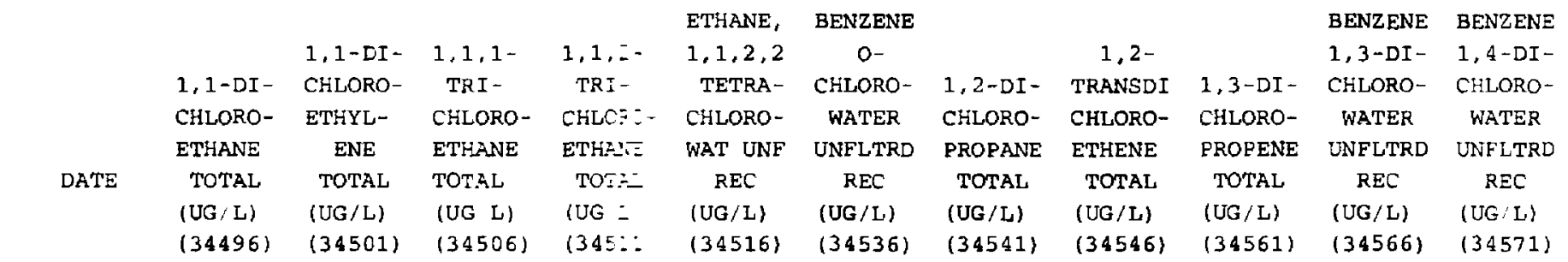

AUG

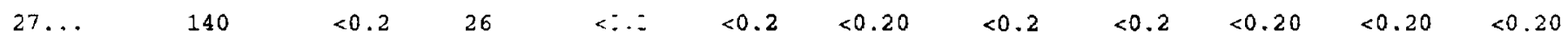




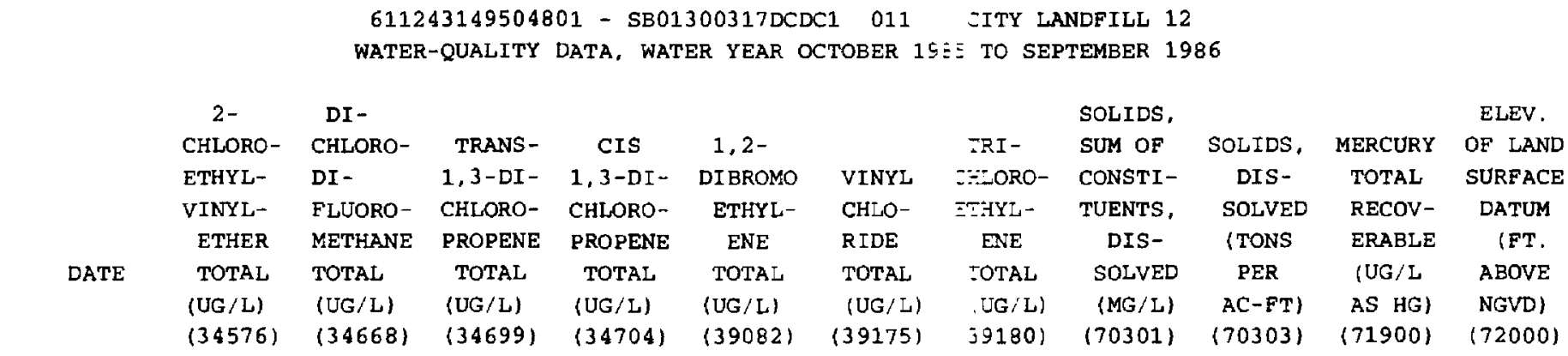

\begin{tabular}{|c|c|c|c|c|c|c|c|c|c|c|c|}
\hline \multicolumn{12}{|l|}{ AUG } \\
\hline \multirow[t]{8}{*}{$27 \ldots$} & $<0.2$ & 90 & $<0.2$ & $<0.2$ & $<0.2$ & 3.9 & 8.0 & 1490 & 2.03 & 0.20 & 122 \\
\hline & & 6112 & 131495048 & $01-\mathrm{SBO1}$ & $300317 \mathrm{DCI}$ & $D C 1 \quad 011$ & EITY LF & NDFILL 12 & & & \\
\hline & & WATEF & QUALITY & DATA， WAT & ZR YEAR & OCTOBER 1 & $\vdots \bar{\perp}$ TO SEF & TEMBER 19 & 86 & & \\
\hline & & PUMP & & & & DEPTH & JEPTH & DEPTH & & SPE- & \\
\hline & & OR FLOW & & & & TO TOP & -O BOT- & BELOW & & CIFIC & ALKA- \\
\hline & DEPTH & PERIOD & & SAM- & DEPTH & $\mathrm{OF}$ & IOM OF & LAND & & $\mathrm{CON-}$ & LINITY \\
\hline & OF & PRIOR & & PLING & OF & SAMPLE & EAMPLE & SURFACE & & DUCT- & LAB \\
\hline & HOLE, & TO SAM- & SAMPLE & CONDI - & WELL, & INTER- & =NTER- & (WATER & STYRENE & ANCE & (MG /L \\
\hline \multirow[t]{2}{*}{ DATE } & $\begin{array}{l}\text { TOTAL } \\
\text { (FEET) }\end{array}$ & $\begin{array}{l}\text { PLING } \\
\text { (MIN) }\end{array}$ & SOURCE & TION & $\begin{array}{l}\text { TOTAL } \\
\text { (FEET) }\end{array}$ & $\begin{array}{l}\text { VAL } \\
\text { (FT) }\end{array}$ & $\begin{array}{l}\text { VAL } \\
\text { (FT) }\end{array}$ & $\begin{array}{l}\text { LEVEL) } \\
\text { (FEET) }\end{array}$ & $\begin{array}{l}\text { TOTAL } \\
\text { (UG/L) }\end{array}$ & $\begin{array}{c}\text { LAB } \\
\text { (US/CM) }\end{array}$ & $\begin{array}{l}\text { AS } \\
\text { CACO3) }\end{array}$ \\
\hline & $(72001)$ & $(72004)$ & $(72005)$ & $(72006)$ & $(72008)$ & $(72015)$ & -20161 & $(72019)$ & (77128) & $(90095)$ & $(90410)$ \\
\hline \multicolumn{12}{|l|}{ AUG } \\
\hline $27 \ldots$ & 50 & 35 & 1 & 1.00 & 49.30 & 29 & 49 & 29.76 & $<0.2$ & 2330 & 877 \\
\hline
\end{tabular}

$611254149501301-\$ B 013003170 \div \div \div 012$

WATER-QUALITY DATA, WATER YEAR OCTOBER $1: \vdots \vdots$ IO SEPTEMBER 1969

\begin{tabular}{|c|c|c|c|c|c|c|c|c|c|c|c|}
\hline \multirow{6}{*}{ DATE } & & & & & & & & \multirow{2}{*}{\multicolumn{4}{|c|}{$\begin{array}{rr} & \text { ALKA- } \\
\text { CARBON } & \text { LINITY }\end{array}$}} \\
\hline & & & & & & & & & & & \\
\hline & & & & & & & COLOR & CIFIC & WHOLE & DIOXIDE & WAT WH \\
\hline & $\begin{array}{l}\text { LAT- } \\
\text { I- }\end{array}$ & $\begin{array}{l}\text { LONG- } \\
\text { I- }\end{array}$ & MEDIUM & SAMPLE & RECORD & 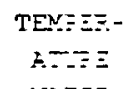 & $\begin{array}{l}\text { (PLAT- } \\
\text { INUM- }\end{array}$ & $\begin{array}{l}\text { CON- } \\
\text { DUCT- }\end{array}$ & $\begin{array}{l}\text { FIELD } \\
\text { (STAND- }\end{array}$ & $\begin{array}{c}\text { DIS- } \\
\text { SOLVED }\end{array}$ & $\begin{array}{c}\text { TOT FET } \\
\text { FIELD }\end{array}$ \\
\hline & TUDE & TUDE & CODE & TYPE & NUMBER & $\begin{array}{l}n \div: \Sigma \overline{0} \\
(D E=\Sigma)\end{array}$ & $\begin{array}{l}\text { COBALT } \\
\text { UNITS) }\end{array}$ & $\begin{array}{c}\text { ANCE } \\
\text { (US /CM) }\end{array}$ & $\begin{array}{l}\text { ARD } \\
\text { UNITS) }\end{array}$ & $\begin{array}{c}(M G / L \\
\text { AS } C O 2)\end{array}$ & $\begin{array}{c}\mathrm{MG} / \mathrm{L} \text { AS } \\
\mathrm{CACO} 3\end{array}$ \\
\hline & & & & & & $10::: 8)$ & $(00080)$ & $(00095)$ & $(00400)$ & $(00405)$ & $(00410)$ \\
\hline
\end{tabular}

MAY

$\begin{array}{lllllllllllllllll}07 \ldots & 61 & 12 & 54 \mathrm{~N} & 149 & 50 & 13 \mathrm{~W} & 6 & 9 & 96900583 & \vdots .5 & 10 & 216 & 8.3 & 1.1 & 113\end{array}$

$611254149501301-\$ B 01300317 D+20012$

WATER-QUALITY DATA, WATER YEAR OCTOBER I: $: \vdots$ TO SEPTEMBER 1969

\begin{tabular}{|c|c|c|c|c|c|c|c|c|c|c|c|}
\hline & $\begin{array}{r}\text { BICAR- } \\
\text { BONATE } \\
\text { WATER }\end{array}$ & $\begin{array}{c}\text { CAR- } \\
\text { BONATE } \\
\text { WATER }\end{array}$ & $\begin{array}{c}\text { NITRO- } \\
\text { GEN, } \\
\text { NITRATE }\end{array}$ & $\begin{array}{l}\text { HARD- } \\
\text { NESS }\end{array}$ & $\begin{array}{l}\text { HARD- } \\
\text { NESS } \\
\text { NONCARB }\end{array}$ & & $\begin{array}{l}\text { WEGNE- } \\
\text { SIUM, }\end{array}$ & & $\begin{array}{c}\text { SODIUM } \\
\text { AD- }\end{array}$ & & $\begin{array}{l}\text { POTAS- } \\
\text { SIUM, }\end{array}$ \\
\hline & $\begin{array}{r}\text { WH FET } \\
\text { FIELD }\end{array}$ & $\begin{array}{r}\text { WH FET } \\
\text { FIELD }\end{array}$ & $\begin{array}{c}\text { DIS- } \\
\text { SOLVED }\end{array}$ & $\begin{array}{l}\text { TOTAL } \\
\text { (MG/L }\end{array}$ & $\begin{array}{l}\text { WH WAT } \\
\text { TOT ELD }\end{array}$ & $\begin{array}{l}\text { DIS- } \\
\text { SOLVED }\end{array}$ & $\begin{array}{l}\text { DIS- } \\
\text { 三OLVED }\end{array}$ & $\begin{array}{l}\text { DIS- } \\
\text { SOLVED }\end{array}$ & $\begin{array}{l}\text { SORP- } \\
\text { TION }\end{array}$ & & $\begin{array}{l}\text { DIS- } \\
\text { SOLVED }\end{array}$ \\
\hline & $\begin{array}{l}\text { MG/L AS } \\
\text { HCO3 } \\
(00440)\end{array}$ & $\begin{array}{c}\text { MG / L AS } \\
C 03 \\
(00445)\end{array}$ & $\begin{array}{c}(M G / L \\
\text { AS N) } \\
(00618)\end{array}$ & $\begin{array}{c}A S \\
\text { CACO3) } \\
(00900)\end{array}$ & $\begin{array}{c}\text { MG I AS } \\
\text { CACO3 } \\
(00902)\end{array}$ & $\begin{array}{c}\text { (MG/L } \\
\text { AS CA) } \\
(00915)\end{array}$ & $\begin{array}{c}\text { XG'L } \\
\therefore \equiv M G) \\
: 0925\}\end{array}$ & $\begin{array}{c}\text { (MG / L } \\
\text { AS NA) } \\
(00930\}\end{array}$ & $\begin{array}{l}\text { RATIO } \\
(00931)\end{array}$ & $\begin{array}{r}\text { SODIUM } \\
\text { PERCENT } \\
(00932\}\end{array}$ & $\begin{array}{l}\text { (MG/L } \\
\text { AS K) } \\
(00935)\end{array}$ \\
\hline
\end{tabular}

MAY

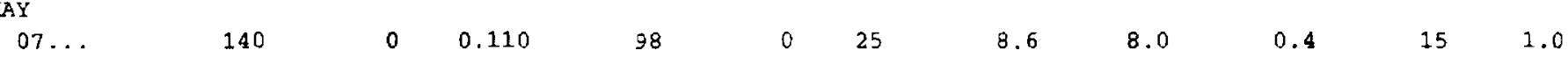

611254149501301 - SB01300317L_-20 012

WATER-QUALITY DATA, WATER YEAR OCTOBER İ

\begin{tabular}{|c|c|c|c|c|c|c|c|c|c|c|}
\hline CHLO- & & FLUO- & SILICA, & $\begin{array}{l}\text { SOLIDS, } \\
\text { SUM OF }\end{array}$ & SOLIDS. & $\begin{array}{c}\text { UITRO- } \\
\text { GEN }\end{array}$ & & $\begin{array}{l}\text { ELEV. } \\
\text { OF LAND }\end{array}$ & & \\
\hline RIDE, & SULFATE & RIDE, & DIS- & CONSTI - & DIS- & $\because$ TRATE & & SURFACE & DEPTH & DEPTH \\
\hline DIS- & DIS- & DIS- & SOLVED & TUENTS, & SOLVEE & DIS- & & DATUM & $O F$ & $O F$ \\
\hline SOLVED & SOLVED & SOLVED & (MG /L & DIS- & (TONS & SOLVED & IRON & (FT. & HOLE, & WELL, \\
\hline $\begin{array}{l}\text { (MG/L } \\
\text { AS CL) }\end{array}$ & $\begin{array}{c}(M G / L \\
\text { AS SO4) }\end{array}$ & $\begin{array}{l}\text { (MG / L } \\
\text { AS F) }\end{array}$ & $\begin{array}{c}\text { AS } \\
\text { SIO2) }\end{array}$ & $\begin{array}{l}\text { SOLVED } \\
\text { (MG, L) }\end{array}$ & $\begin{array}{c}\text { PER } \\
\text { AC-FT) }\end{array}$ & $\begin{array}{c}\text { MG L } \\
\therefore \equiv \text { NO3, }\end{array}$ & $\begin{array}{l}(U G / \tilde{L} \\
A S F E)\end{array}$ & $\begin{array}{l}\text { ABOVE } \\
\text { NGVD) }\end{array}$ & $\begin{array}{l}\text { TOTAL } \\
\text { (FEET) }\end{array}$ & $\begin{array}{l}\text { TOTAL } \\
\text { (FEET) }\end{array}$ \\
\hline$(00940)$ & $(00945)$ & $(00950)$ & $(00955)$ & $(70301)$ & $(70303)$ & $-1851)$ & $(71885)$ & $(72000)$ & $(72001)$ & $(72008)$ \\
\hline
\end{tabular}

MAY

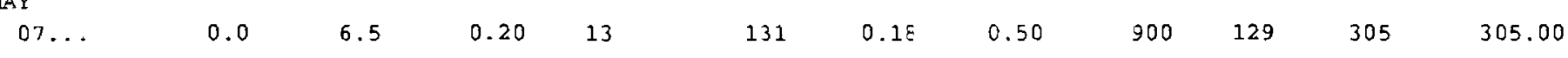


611255149495801 - SB01300316CBDB1 005 WATER -QUALITY DATA, WATER YEAR OCTOBER 1967 TO SEPTEMBER 1968

\begin{tabular}{|c|c|c|c|c|c|c|c|c|c|c|c|}
\hline & & & & & & & & PH & & ALKA- & BICAR - \\
\hline & & & & & & & SPE- & WATER & CARBON & LINITY & BONATE \\
\hline & & & & & & COLOR & CIFIC & WHOLE & DIOXIDE & WAT WH & WATER \\
\hline & LAT- & LONG- & & & & (PLAT- & $\mathrm{CON}-$ & FIELD & DIS- & TOT FET & WH FET \\
\hline & I- & I- & MEDIUM & SAMPLE & RECORD & INUM- & DUCT- & (STAND- & SOLVED & FIELD & FIELD \\
\hline DATE & TUDE & TUDE & CODE & TYPE & NUMBER & COBALT & ANCE & ARD & (MG /L & MG $/ L$ AS & MG/L AS \\
\hline & & & & & & UNITS) & (US/CM) & UNITS) & AS $\mathrm{CO} 21$ & $\mathrm{CACO} 3$ & $\mathrm{HCO} 3$ \\
\hline & & & & & & $(00080)$ & $(00095)$ & $(00400)$ & $(00405)$ & $(00410)$ & $(00440)$ \\
\hline
\end{tabular}

AUG

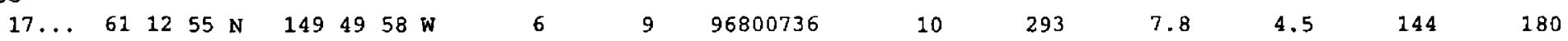

611255149495801 - SB01300316CBDB1 005

WATER-QUALITY DATA, WATER YEAR OCTOBER 1967 TO SEPTEMBER 1968

\begin{tabular}{|c|c|c|c|c|c|c|c|c|c|c|c|}
\hline & $\begin{array}{l}\text { CAR- } \\
\text { BONATE } \\
\text { WATER }\end{array}$ & $\begin{array}{c}\text { NITRO- } \\
\text { GEN, } \\
\text { NITRATE }\end{array}$ & $\begin{array}{l}\text { HARD- } \\
\text { NESS }\end{array}$ & $\begin{array}{l}\text { HARD- } \\
\text { NESS } \\
\text { NONCARB }\end{array}$ & CALCIUM & $\begin{array}{l}\text { MAGNE- } \\
\text { SIUM, }\end{array}$ & SODIUM, & $\begin{array}{c}\text { SODIUM } \\
\text { AD- }\end{array}$ & & $\begin{array}{c}\text { POTAS- } \\
\text { SIUM, }\end{array}$ & $\begin{array}{l}\text { CHLO- } \\
\text { RIDE, }\end{array}$ \\
\hline & $\begin{array}{l}\text { WH FET } \\
\text { FIELD }\end{array}$ & $\begin{array}{l}\text { DIS- } \\
\text { SOLVED }\end{array}$ & $\begin{array}{l}\text { TOTAL } \\
\text { (MG / L }\end{array}$ & $\begin{array}{l}\text { WH WAT } \\
\text { TOT FLD }\end{array}$ & $\begin{array}{l}\text { DIS- } \\
\text { SOLVED }\end{array}$ & $\begin{array}{c}\text { DIS- } \\
\text { SOLVED }\end{array}$ & $\begin{array}{l}\text { DIS- } \\
\text { SOLVED }\end{array}$ & $\begin{array}{l}\text { SORP- } \\
\text { TION }\end{array}$ & & $\begin{array}{c}\text { DIS- } \\
\text { SOLVED }\end{array}$ & $\begin{array}{l}\text { DIS- } \\
\text { SOLVED }\end{array}$ \\
\hline \multirow[t]{3}{*}{ ATE } & MG/L AS & (MG / L & AS & MG / L AS & (MG / L & (MG / L & (MG / L & RATIO & SODIUM & (MG /L & (MG /L \\
\hline & $\operatorname{co3}$ & AS N) & (ACO3) & $\mathrm{CACO} 3$ & AS CA) & AS MG) & AS NA) & & PERCENT & AS K) & AS CL) \\
\hline & $(00445)$ & $(00618)$ & $(00900)$ & $(00902)$ & $(00915)$ & $(00925)$ & $(00930)$ & $(00931)$ & $(00932)$ & $(00935)$ & $(00940)$ \\
\hline
\end{tabular}

AUG

$\begin{array}{llllllllllll}17 \ldots & 0 & 0.050 & 120 & 0 & 30 & 12 & 16 & 0.6 & 22 & 2.2 & 5.8\end{array}$

611255149495801 - SB01300316CBDB1 005

WATER-QUALITY DATA, WATER YEAR OCTOBER 1967 TO SEPTEMBER 1968

\begin{tabular}{|c|c|c|c|c|c|c|c|c|c|c|}
\hline & FLUO- & SILICA, & $\begin{array}{l}\text { SOLIDS, } \\
\text { SUM OF }\end{array}$ & SOLIDS, & $\begin{array}{l}\text { NITRO- } \\
\text { GEN. }\end{array}$ & $\begin{array}{l}\text { ELEV. } \\
\text { OF LAND }\end{array}$ & & & $\begin{array}{l}\text { DEPTH } \\
\text { TO TOP }\end{array}$ & $\begin{array}{l}\text { DEPTH } \\
\text { TO BOT- }\end{array}$ \\
\hline $\begin{array}{l}\text { SULFATE } \\
\text { DIS- }\end{array}$ & $\begin{array}{l}\text { RIDE, } \\
\text { DIS- }\end{array}$ & $\begin{array}{l}\text { DIS- } \\
\text { SOLVED }\end{array}$ & $\begin{array}{l}\text { CONSTI- } \\
\text { TUENTS, }\end{array}$ & $\begin{array}{c}\text { DIS- } \\
\text { SOLVED }\end{array}$ & $\begin{array}{c}\text { NITRATE } \\
\text { DIS- }\end{array}$ & $\begin{array}{l}\text { SURFACE } \\
\text { DATUM }\end{array}$ & $\begin{array}{l}\text { DEPTH } \\
\text { OF }\end{array}$ & $\begin{array}{l}\text { DEPTH } \\
\text { OF }\end{array}$ & $\begin{array}{c}\text { OF } \\
\text { SAMPLE }\end{array}$ & $\begin{array}{l}\text { TOM OF } \\
\text { SAMPLE }\end{array}$ \\
\hline $\begin{array}{l}\text { SOLVED } \\
\text { (MG / L }\end{array}$ & $\begin{array}{l}\text { SOLVED } \\
\text { (MG / L }\end{array}$ & $\begin{array}{l}\text { (MG / L } \\
A S\end{array}$ & $\begin{array}{c}\text { DIS- } \\
\text { SOLVED }\end{array}$ & $\begin{array}{l}\text { ITONS } \\
\text { PER }\end{array}$ & $\begin{array}{l}\text { SOLVED } \\
\text { (MG / L }\end{array}$ & $\begin{array}{c}\text { (FT. } \\
\text { ABOVE }\end{array}$ & $\begin{array}{l}\text { HOLE, } \\
\text { TOTAL }\end{array}$ & $\begin{array}{l}\text { WELL, } \\
\text { TOTAL }\end{array}$ & $\begin{array}{c}\text { INTER- } \\
\text { VAL }\end{array}$ & $\begin{array}{l}\text { INTER- } \\
\text { VAL }\end{array}$ \\
\hline AS SO4) & AS F) & SIO2) & $(M G / L)$ & $A C-E T)$ & AS NO3) & NGVD) & (FEET) & (FEET) & (FT) & (FT) \\
\hline$(00945)$ & $(00950)$ & $(00955)$ & $(70301)$ & $(70303)$ & $(71851)$ & $(72000)$ & $(72001)$ & $(72008)$ & $(72015)$ & $(72016)$ \\
\hline
\end{tabular}

AUG

$\begin{array}{lllllllllll}17 \ldots & 10 & 0.20 & 10 & 173 & 0.24 & 0.20 & 132 & 170 & 170.00 & 170\end{array}$

611306149495701 - SB01300316BCCD1 004

WATER-QUALITY DATA, WATER YEAR OCTOBER 1956 TO SEPTEMBER 1957

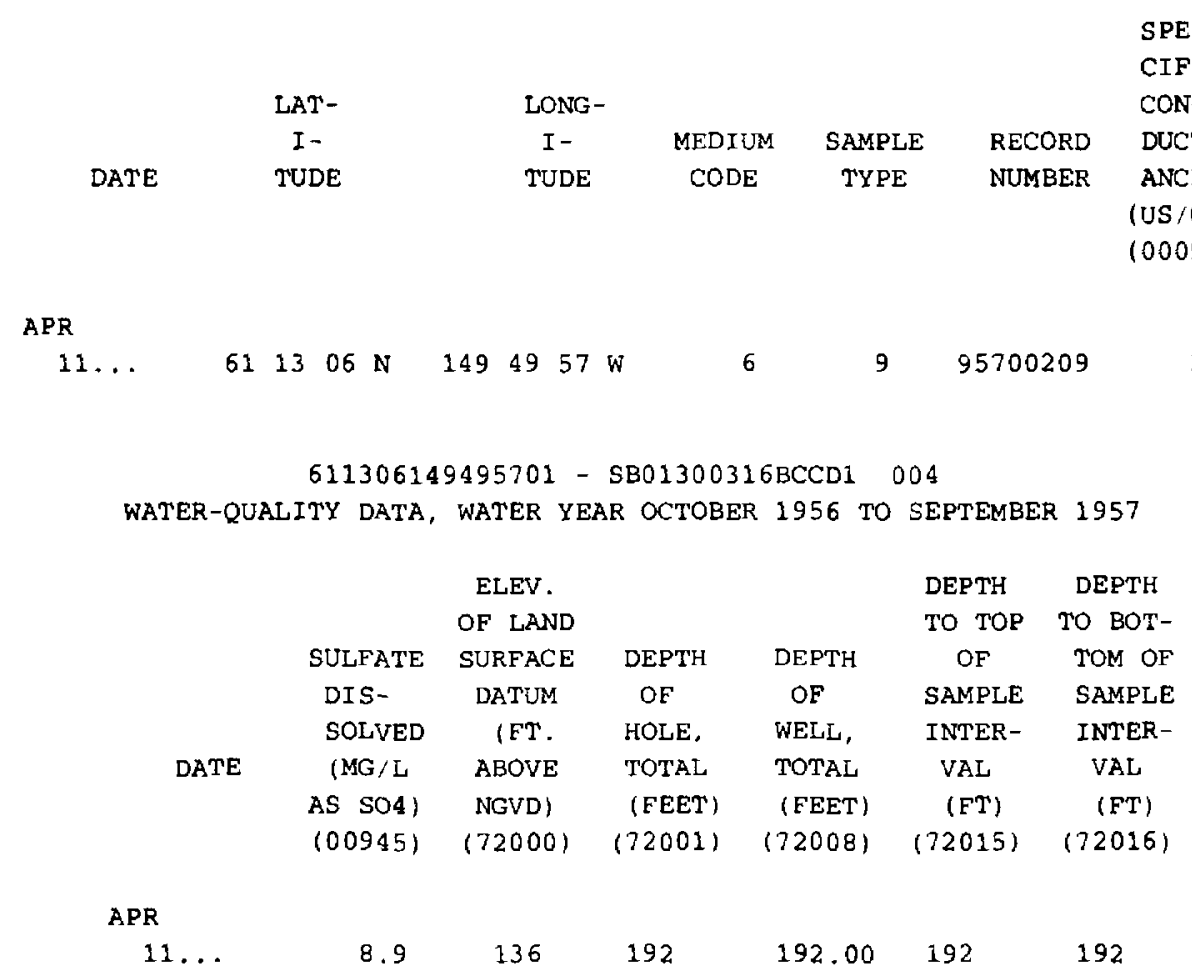

PE-

CIFIC

CON-

ANCE

US / CM)

00095)

$\begin{array}{lllllll}11 \ldots & 8.9 & 136 & 192 & 192.00 & 192 & 192\end{array}$ 